Illinois State University

ISU ReD: Research and eData

Theses and Dissertations

$10-12-2020$

\title{
Being Black While Leading: A Mixed Methods Study Of Black Administrators' Experiences In U.S. Public Schools
}

Latasha Marie Schraeder

Illinois State University, latashaschraeder@gmail.com

Follow this and additional works at: https://ir.library.illinoisstate.edu/etd

Part of the Special Education Administration Commons

\section{Recommended Citation}

Schraeder, Latasha Marie, "Being Black While Leading: A Mixed Methods Study Of Black Administrators' Experiences In U.S. Public Schools" (2020). Theses and Dissertations. 1347.

https://ir.library.illinoisstate.edu/etd/1347

This Dissertation is brought to you for free and open access by ISU ReD: Research and eData. It has been accepted for inclusion in Theses and Dissertations by an authorized administrator of ISU ReD: Research and eData. For more information, please contact ISUReD@ilstu.edu. 


\section{BEING BLACK WHILE LEADING: A MIXED METHODS STUDY OF BLACK ADMINISTRATORS' EXPERIENCES IN U.S. PUBLIC SCHOOLS}

\section{LATASHA MARIE SCHRAEDER}

\section{Pages}

This transformative explanatory sequential mixed methods design study framed by the theories of Critical Race Theory and Community Cultural Wealth used a survey and semistructured interviews to explore the experiences of Black administrators in PK-12 public schools in the United States. Within the first, quantitative, phase of the study participants completed a survey that collected demographic data and responses related to the six forms of cultural capital via Likert Scale style and opened ended questions. There were 65 responses, with $42(\mathrm{~N}=42)$ of the responses being complete. In the second, qualitative, phase of the study two participants were interviewed to gather data related to their experiences as Black administrators. The study found participants were able to use cultural capital to navigate barriers encountered during their attempts to create culturally responsive practices and policies. Black administrators are competent, servant leaders who are driven to persevere to create equitable experiences for Black, Indigenous and Latinx students. Professional development related to cultural competence and culturally responsive teaching practices and policies must take priority and systemic racist and biased policies that exist in public schools in the United States must be addressed. An increase in the number of Black administrators who are able to form relationships with Black, Indigenous and Latinx students based on shared lived experiences will increase the likelihood of students' success through the implementation of culturally responsive practices and policies. 
KEYWORDS: Administrator, Culturally Responsive Teaching Practices, Educational Equity 
BEING BLACK WHILE LEADING: A MIXED METHODS STUDY OF BLACK ADMINISTRATORS' EXPERIENCES IN U.S. PUBLIC SCHOOLS

LATASHA MARIE SCHRAEDER

A Dissertation Submitted in Partial Fulfillment of the Requirements for the Degree of

DOCTOR OF EDUCATION

Department of Special Education

ILLINOIS STATE UNIVERSITY

2020 
Copyright 2020 Latasha Marie Schraeder 
BEING BLACK WHILE LEADING: A MIXED METHODS STUDY OF BLACK ADMINISTRATORS' EXPERIENCES IN U.S. PUBLIC SCHOOLS

LATASHA MARIE SCHRAEDER

COMMITTEE MEMBERS:

Debbie Shelden, Chair

April Mustian

Mark Zablocki 


\section{ACKNOWLEDGMENTS}

I would like to express my deepest gratitude to those who have played significant roles in my successful completion of this dissertation. First, I thank God for gifting me with everything I needed to recognize and walk in my purpose. I also want to thank my husband, Scott, for being a true partner in this doctoral journey. It takes an extraordinary man to stand beside a wildly ambitious woman and allow her to pursue her dreams. We did it! Next, I want to thank my three children Zoe, Joshua and Maximilian for understanding that I dedicated the last four years to this journey, sometimes sacrificing time spent together, so our lives could be greater later. I love all of you to life! I also want to thank my ISU family with whom I began this journey in the fall of 2016. We had no idea what we were getting ourselves into! Next, I want to thank the professors who always believed I'd become Latasha M. Schraeder, Ed.D.: Dr. Karen Douglas, Dr. Yojanna Cuenca-Carlino, Dr. Tara Kaczorowski, and Dr. Yun Ching-Chung. Last, I would be remiss if I did not express my appreciation to my doctoral committee: Dr. Debbie Shelden, Dr. April Mustian, and Dr. Mark Zablocki. I will remain forever grateful for this journey of growth, selfdiscovery and self-discipline. 


\section{CONTENTS}

Page

ACKNOWLEDGMENTS

TABLES Di

FIGURES vii

CHAPTER I: INTRODUCTION 1

Statement of the Problem 1

Inequitable School Experiences of Black, Indigenous, and Latinx Students 1

$\begin{array}{ll}\text { Contributing Factors to Academic Inequities } & 6\end{array}$

$\begin{array}{ll}\text { Current Research Base } & 11\end{array}$

Synthesized Findings of the Current Research 13

Limitations of Current Research Base $\quad 15$

$\begin{array}{ll}\text { Summary } & 15\end{array}$

Purpose of Study and Research Questions 16

$\begin{array}{ll}\text { Significance of the Study } & 17\end{array}$

$\begin{array}{ll}\text { Limitations/Delimitations } & 17\end{array}$

$\begin{array}{ll}\text { Definition of Terms } & 18\end{array}$

CHAPTER II: LITERATURE REVIEW 20

$\begin{array}{ll}\text { Theoretical Framework } & 20\end{array}$

$\begin{array}{ll}\text { Critical Race Theory } & 20\end{array}$

$\begin{array}{ll}\text { Community Cultural Wealth } & 22\end{array}$

Inequitable Educational Experiences of BIaLS Through a Critical Lens 23

$\begin{array}{ll}\text { School Discipline } & 24\end{array}$ 
$\begin{array}{ll}\text { Lack of Access } & 24\end{array}$

Lower Academic Achievement $\quad 25$

$\begin{array}{ll}\text { Overrepresentation in Special Education } & 27\end{array}$

Hypothesized Causes of Educational Inequities for BIaLS 28

$\begin{array}{ll}\text { Institutional Racism } & 28\end{array}$

$\begin{array}{lr}\text { Whiteness } & 29\end{array}$

Lack of Cultural Competency $\quad 32$

$\begin{array}{ll}\text { Proposed Solutions to Inequities } & 33\end{array}$

Improved Teacher Preparation for Cultural Responsiveness 33

Recruitment of Black Teachers 35

Black Educational Leadership Opportunities 37

Why There Are So Few Black Administrators 39

$\begin{array}{ll}\text { Barriers } & 40\end{array}$

$\begin{array}{ll}\text { Successes } & 43\end{array}$

$\begin{array}{ll}\text { CHAPTER III: METHODS } & 50\end{array}$

$\begin{array}{ll}\text { Mixed Methods Design } & 50\end{array}$

Transformative Explanatory Sequential Design $\quad 50$

$\begin{array}{ll}\text { Challenges } & 53\end{array}$

$\begin{array}{ll}\text { Participants } & 54\end{array}$

$\begin{array}{ll}\text { Instruments } & 55\end{array}$

$\begin{array}{ll}\text { Survey } & 55\end{array}$

Interview Protocol

$\begin{array}{ll}\text { Data Analysis } & 60\end{array}$ 
$\begin{array}{ll}\text { Analysis of Survey Data } & 60\end{array}$

$\begin{array}{ll}\text { Analysis of Interview Data } & 61\end{array}$

$\begin{array}{ll}\text { Researcher Positionality } & 65\end{array}$

Resources and Skills of the Researcher to Conduct Mixed Methods Research 66

$\begin{array}{ll}\text { Ethical Concerns } & 67\end{array}$

$\begin{array}{ll}\text { CHAPTER IV: RESULTS } & 68\end{array}$

The Affect of Community Cultural Wealth on the Experiences of Black Administrators 68

$\begin{array}{ll}\text { Open Ended Questions } & 73\end{array}$

$\begin{array}{ll}\text { Interview Data } & 79\end{array}$

Positive Experiences of and Barriers Encountered by Black Administrators 80

Describing Self: Identifying the Individual $\quad 80$

Exploring the Advantages of Being Black: Drive and Perseverance 82

Navigating Administrative Roles: Service and Competencies $\quad 82$

$\begin{array}{ll}\text { Encountering Racism } & 84\end{array}$

Overcoming Barriers to Create Equity Through Cultural Responsiveness 86

Describing Self: Identifying the Individual 86

Exploring the Advantages of Being Black: Drive and Perseverance 87

Navigating Administrative Roles: Competencies and Service $\quad 88$

$\begin{array}{lr}\text { Encountering Racism } & 89\end{array}$

$\begin{array}{ll}\text { Conclusions } & 91\end{array}$

CHAPTER V: DISCUSSION

$\begin{array}{ll}\text { Interpretation of The Findings } & 94\end{array}$

$\begin{array}{ll}\text { Quantitative Data } & 94\end{array}$ 
$\begin{array}{ll}\text { Qualitative Data } & 97\end{array}$

Implications for Theory and Research 99

Critical Race Theory and Community Cultural Wealth 99

$\begin{array}{ll}\text { Implications for Practice } & 103\end{array}$

$\begin{array}{ll}\text { Limitations } & 105\end{array}$

Recommendations for Future Research 106

$\begin{array}{ll}\text { Conclusion } & 107\end{array}$

$\begin{array}{ll}\text { REFERENCES } & 109\end{array}$

APPENDIX A: STUDY THROUGH LENS OF CRITICAL RACE THEORY 135

APPENDIX B: Sequential Explanatory Mixed Methods DesigN 136

$\begin{array}{ll}\text { APPENDIX C: SURVEY } & 137\end{array}$

APPENDIX D: PREPARED INTERVIEW QUESTIONS 147 


\section{TABLES}

Table

Page

1. Demographic Data of Survey Respondents

2. Demographic Data of Survey Respondents' Schools 56

3. Survey Response Items by Form of Community Cultural Wealth 58

4. Percentage of Responses Distributed Across Response Options 69 


\section{FIGURES}

Figure $\quad$ Page

1. Diagram: First Cycle Coding $\quad 63$

2. Diagram: Second Cycle Themes and Subthemes $\quad 64$

3. Study Through Lens of Critical Race Theory 134

4. Sequential Explanatory Mixed Methods Design 135

5. Survey, Being Black While Leading: A study of Black administrators' 136

experiences in U.S. public schools 136 


\section{CHAPTER I: INTRODUCTION}

\section{Statement of the Problem}

Previous research has shown culturally relevant pedagogy (CRP) is a means to promote academic achievement for Black, Indigenous, and Latinx students (BIaLS; Au, 2009; Eubanks \& Weaver, 2009; Marks, 2005; Schmeichel, 2012; St. Mary et al., 2018; Wiggan, 2008). Despite this knowledge, in PK-12 public schools in the United States there is still an educational debt owed to BIaLS (Ladson-Billings, 2006; St. Mary et al., 2018). Several barriers to successfully narrowing the opportunity gap between BIaLS and their White counterparts have been identified.

Similar to the experience of BIaLS, Black administrators' experience is unlike that of their White counterparts. Black administrators do have some positive experiences. While this may be true, they also experience barriers in the form of community, distrust, racism, and stereotypes (Bloom \& Erlandson, 2003; Brooks \& Jean-Marie, 2007; Henderson 2015; Loder, 2005; Moore 2013). First, though, it is important to provide the landscape of inequities experienced by BIaLS and Black administrators in public schools.

\section{Inequitable School Experiences of Black, Indigenous, and Latinx Students}

Black, Indigenous and Latinx students have a long history of inequitable school experiences compared to their White peers. Disproportionate school discipline (Skiba et al., 2011; Skiba et al., 2002), lack of access to gifted and talented programs (Ford, 2014; Ford \& King, 2014; Grissom, \& Redding, 2016), lack of access to advanced placement (AP) and coursework in secondary grades (Corra et al., 2011; Davis et al., 2019; Vega et al., 2015), lower academic achievement outcomes (Ladson-Billings, 2006; St. Mary et al., 2018; Williams et al., 2002), and overrepresentation in special education (Blanchett, 2006; Dever et al., 2016; Skiba et 
al. 2008; Skiba et al., 2005; Sullivan \& Bal, 2013) have been clear ways in which disparate treatment of BIaLS has been evidenced.

\section{School Discipline}

Black, Indigenous, and Latinx students are subject to exclusionary discipline at a higher rate than their White peers (Skiba et al., 2011; Skiba et al., 2002). Discipline data for the last four decades has shown BIaLS have been subject to exclusionary discipline at two to three times the rate of their White peers (Skiba et al., 2011; Skiba et al., 2002). In addition, schools with high rates of exclusionary discipline have lower rates of academic achievement (American Psychological Association, 2006; Gion et al., 2018). According to the Office of Civil Rights (OCR) at the U.S. Department of Education (2014) although Black students account for 16\% of the student population they represent $40 \%$ of out of school suspensions. Likewise, Indigenous students make up $1 \%$ of the student population, but represent nearly $2 \%$ of out of school suspensions. Gion et al. (2018) found Indigenous students were overrepresented in office discipline referrals at the secondary level.

\section{Lack of Access}

Black and Latinx students are less likely than White students to be identified for a gifted program even if they meet the indicators for inclusion (Ford et al., 2008; McBee, 2006). Significant disparities exist when considering students in gifted education (Grissom \& Redding, 2016). According to the OCR at the U.S. Department of Education (2014) although Black students account for $16 \%$ of the student population they make up less than $10 \%$ of students in gifted education. Taliaferro and DeCuir-Gunby (2008) suggest the disparity occurs because Black students are less likely to be recommended for AP courses by their teachers. Similarly, Hispanic students make up $25 \%$ of the student population but represent only $18 \%$ of students in 
gifted education, and Indigenous students make up 1\% of the student population but represent less than $1 \%$ of students in gifted education. In addition, Black students are less likely to attend a school with a gifted program. According to data from the Early Childhood Longitudinal Study Kindergarten Cohort, $83 \%$ of Black students attend schools with a gifted program as compared to $90 \%$ of White, $91 \%$ of Asian, and $93 \%$ of Hispanic students. This opportunity gap has the potential to limit future outcomes for BIaLS (Card \& Giuliano, 2014; Delcourt et al., 2007; Grissom \& Redding, 2016; Rogers, 2007).

Moreover, disparities in representation of Black students in AP courses are similar to those in gifted courses. There exists an opportunity gap for BIaLS in placement in AP courses (Taliaferro \& DeCuir-Gunby, 2008). According to the OCR at the U.S. Department of Education (2014) although Black students account for 16\% of the student population they make up less than $10 \%$ of students in AP courses. Likewise, Hispanic students make up 25\% of the student population, but represent only $19 \%$ of students and Indigenous students make up less than $1 \%$ of students in AP courses.

\section{Lower Academic Achievement}

The average National Assessment of Education Progress (NAEP) reading scale score for Black students was 26 points lower, the average reading scale score for Hispanic students was 23 points lower, and the average reading scale score for Indigenous students was 30 points lower than White students. Further, according to the National Center for Education Statistics (NCES, 2019b), the average NAEP math scale score for Black students was 25 points lower, the average reading scale score for Hispanic students was 19 points lower, and the average reading scale score for Indigenous students was 21 points lower than White students. 
Schools serving Black students often have (a) larger class sizes, (b) inferior curricula and facilities, (c) fewer funding sources, and (d) less qualified teachers (Condron et al., 2013; Rowley \& Wright, 2011). Black and Latinx students are tracked in lower ability groups and are retained at a higher rate than their White peers (Brayboy et al., 2007; Meece \& Kurtz-Costes, 2001). Racists policies and perceptions play a role in BIaLS lack of academic achievement (Blanchett, 2006; Brayboy et al., 2011; Thomas, 2004). Historically, it has been difficult for Black students in the United States to receive an education equal to that of their White peers (Diemer, Marchand, McKellar, \& Malanchuk, 2016; St. Mary, Calhoun, Tejada, \& Jenson, 2018; Wiggan, 2008). Due to the educational debt, Black and Latinx students have earned less than average grades and have not met expectations on standardized assessments (Ladson-Billings, 2006; Williams et al., 2002).

The inequities caused by the educational debt are numerous and include but are not limited to (a) inadequate facilities, (b) inexperienced, substitute or subpar teachers, and (c) low level curriculums or curriculums that do not mirror the experience of BIaLS (Brayboy et al., 2007; Casey, 2004; Ford, 2014; Ford \& King, 2014; McKown, 2013; Scott et al., 2018; TalbertJohnson, 2004). These inequities are barriers to BIaLS receiving educations that are equal to their peers (Casey, 2004; McKown, 2013; Rowley \& Wright, 2011; Scott et al., 2018).

In addition to the lack of quality teachers and facilities, BIaLS are often expected to learn from a curriculum that does not draw from their experience. Curriculums presented to Black students are less rigorous, focusing on low level skills required for standardized assessment which are often culturally and or linguistically biased (Brayboy et al., 2007). The focus on low level skills leads to few opportunities for genuine learning experiences. Curricular 
materials and content do not represent the lived experiences of BIaLS which makes it difficult for BIaLS to make connections that lead to learning (Bernal, 2002; Brayboy et al., 2007). Moreover, BIaLS are often taught by underprepared teachers. In fact, BIaLS are more likely to be taught by substitute teachers, subpar teachers, or teachers who completed alternative certificate programs to obtain their educator licensure (Condron et al., 2013; Darling-Hammond, 2000; Talbert-Johnson, 2004). Despite the fact research indicates it is improbable students can recover from valuable instructional minutes received from novice underprepared teachers (Casey, 2004), schools that serve BIaLS are more likely to be staffed by less experienced teachers (Aud et al., 2010; Eubanks \& Weaver, 1999; Mickelson, 2001). According to the National Commission on Teaching and America's Future (1996) nearly 30\% of newly hired teachers have temporary licensure, substitute licensure or lack any form of teacher licensure. To exacerbate the effects of inferior teaching, public schools in urban areas of the United States are often housed in facilities that are in disrepair and equipped with aged and or obsolete technology (Casey, 2004, Condron et al., 2013). The opportunity gap that exists between White students and BIaLS affects their socioeconomic status for a lifetime (Condron, et al., 2013; Levin, 2009; McKown, 2013; Oliver \& Shapiro, 2006; Reardon \& Robinson, 2007).

\section{Overrepresentation in Special Education}

Black, Indigenous, and Latinx students are identified for special education at a higher rate than their White peers (Dever et al., 2016; Skiba et al. 2008; Skiba et al., 2005; Sullivan \& Bal, 2013). According to the OCR (2014) Black students represent $19 \%$ of students being served under the Individual with Disabilities Education Improvement Act (IDEA), although they account for only $16 \%$ of the students enrolled in public schools in the United States. According to Blanchett (2006), racism contributes to the disproportionate placement of BIaLS into special 
education programs as exhibited by (a) insufficient funding provided to schools serving students of color, (b) the use of culturally insensitive curricula, and (c) the placement of teachers who are underprepared to teach BIaLS. In addition, the limited access to resources in urban settings have led to BIaLS being misidentified for special education services (Talbert-Johnson, 2001, 2004).

\section{Contributing Factors to Academic Inequities}

\section{Cultural Mismatch in the Teaching Population}

A pervasive mismatch between teacher and students has existed for decades in that a disproportionately high number of White educators continue to teach a student population that is becoming more diverse over time (Frankenberg, 2009; Shen et al., 2003). Within public schools in the United States an inordinate number of teachers are White and there is a divide between the number of BIaLS in the public schools in the United States and the diversity of the teaching force (Eubanks \& Weaver, 2009; Frankenberg, 2009; Shen et al., 2003).). In fact, it is not uncommon for teachers to carry bias that negatively impacts Black students (St. Mary et al., 2018). Since the Supreme Court decision in Brown v. Board of Education (1954), the proportion of White teachers providing instruction to BIaLS has increased (Fergus, 2017; Goldring et al., 2014).

According to Frankenberg (2009), the exposure to diversity found in teachers from diverse ethnic backgrounds will allow them to draw from their culturally diverse experiences when teaching in schools serving BIaLS . The disproportionate number of White educators often lack culturally diverse experiences to draw from when teaching Black students (Wiggan, 2008). Teachers from diverse ethnic backgrounds can (a) act as role models for BIaLS and help White students recognize and accept diversity, (b) bring a more robust knowledge base and commitment to social justice, and (c) hold high expectations for all students (Frankenberg, 
2009). Teachers of color bring many benefits to students served in multicultural classrooms.

Teachers are one of the most important factors when considering outcomes for students (DarlingHammond, 2003; Frankenberg, 2009). For instance, teachers of color can serve as role models to all students (Eubanks \& Weaver, 1999). Regrettably, the NCES staffing data confirm that teachers of color represent a significantly smaller percentage of the teaching field than do BIaLS in comparison to national student enrollment.

White teachers tend to enroll in White, middle-class schools and live in White communities which potentially leads to a lack of understanding or relating to BIaLS who have not received the advantage of White privilege (e.g., middle-class income, safe neighborhoods, culturally relevant curricula) (Frankenberg, 2009; Sleeter, 2007, Villegas \& Lucas, 2002). Further, many teachers have few lived or educational experiences that allow them to associate with BIaLS or students with a different social economic status (Fergus, 2017; Frankenberg, 2009). Diverse and culturally responsive teachers can play a significant role in closing the opportunity gap that exists among BIaLS who reside in multicultural neighborhoods by providing context and meaning within their classrooms (Au, 2009; Eubanks \& Weaver, 2009; Marks, 2005; Schmeichel, 2012; St. Mary et al., 2018).

\section{Lack of Black Representation in Administrative Positions}

By numbers alone, the fact that Black teachers comprise only $7 \%$ of U.S. public school teachers (U.S. Department of Education, National Center for Education Statistics and OCR, 2016b), means that relatively few public-school administrators are Black. Further, Black teachers who aspire to and are worthy of formal leadership positions face additional barriers as they work against institutional racism. This disproportionately low representation serves as an additional barrier to systemic equity for BIaLS. 
Black administrators have yet to recover from the setbacks set in motion by the Brown v. Board of Education (1954) decision (Brown, 2005; Tillman, 2003; Valverde, 2003). The number of Black administrators in the United States has diminished, a decrease originating during the Civil Rights Era (Brown, 2005; Fultz, 2004; McCray et al., 2007; Sanchez et al., 2008; Tillman, 2004; Valverde, 2003). Currently in the United States there are roughly 90,000 administrators serving in PK-12 public school settings (U.S. Department of Education, 2018). According to the U.S. Department of Education (2016), 1 in 10 of those administrators identify as Black.

Brown v. Board of Education. Prior to the Civil Rights Movements, Black administrators were viewed as less competent than their White counterparts in the U.S. public school system. The leadership roles in segregated schools held by Black administrators were considered inconsequential and their ability to lead was perceived as insufficient. Consequently, as schools were integrated following the Supreme Court's ruling in Brown v. Board of Education (1954) that deemed segregated schools unconstitutional, Black administrators' capacity to lead was considered inadequate. This perception of inadequacy lead to the inability to secure a legitimate leadership position as a Black administrator (Foster, 2005; Jones, 2002). Brown v. Board of Education had an unintentional but devastating effect on the number of legitimate leadership roles available to Black educators (Brown, 2005; McCray et al., 2007).

Placement. As a result of the low number of Black administrators, schools have been unable to provide role models or culturally responsive learning environments for Black and Latinx (Meece \& Kurtz-Costes, 2001). Currently, the pattern of placement of administrators indicates the placement of Black administrators in schools that serve predominately Black students and the placement of White administrators in schools serving more diverse student populations (Brown, 2005; McCray et al., 2007; Tillman, 2004). The addition of a Black 
administrator in schools serving BIaLS would be more likely to create learning environments that promotes and takes advantage of cultural diversity (Jones, 2002; Meece \& Kurtz-Costes, 2001). In addition, Black administrators are able to lead through a lens of cultural relevance as supported by their lived experiences (Hammond, 2015). As the use of CRP is an established strategy in addressing the educational debt owed BIaLS, the disproportionate number of Black administrators in the PK-12 public school setting in the United States must be addressed (Au, 2009; Eubanks \& Weaver, 2009; Marks, 2005; Schmeichel, 2012; St. Mary et al., 2018).

Black educators aspiring to and sustaining leadership positions encounter numerous barriers and must overcome them to ascend to or sustain leadership positions. A myriad of barriers exist that a qualified educator must overcome based solely on the fact that he or she is Black. Barriers to leadership roles encountered by Black educators include, but are not limited to, (a) fatigue and health issues, (b) the lack of professional development, (c) the lack of social capital, and (d) racism (Brubaker \& Coble, 2007; Echols, 2006; Henderson, 2015, Jean-Marie, 2013; Marshall, 2004; Wilkerson \& Wilson, 2017).

Fatigue and Health Issues. As Black administrators often serve in under resourced schools, the potential to become overwhelmed is great (Echols, 2006; Wilkerson \& Wilson, 2017). Echols (2006) found Black administrators reported their work caused elevated amounts of stress. These administrators reported health concerns such as high blood pressure, cardiovascular disease, and diabetes as related to stress caused by their administrative positions.

Professional Development. A lack of professional development is a barrier to Black administrators experiencing success in leadership roles. This has the potential to stifle professional growth or hinder career advancement (Brubaker \& Coble, 2007; Wilkerson \& Wilson, 2017). Many administrators lack sufficient training related to serving students (a) living 
in poverty, (b) who speak English as a second language, (c) who have special needs, or (d) identify as BIaLS (Marshall, 2004). Wilkerson and Wilson (2017) suggest the most important professional development is training that aides school administrators in sending clear messages to their faculty and staff about the need for change (e.g., setting high academic expectations and improving instructional quality).

Racism. Black administrators also encounter racism as a barrier to opportunities for leadership roles and while navigating their administrative positions (Echols, 2006; Henderson, 2015, Jean-Marie, 2013). Some Black administrators experience racism in the form of the perception that Black administrators do not possess the skills to be a good leader (Henderson, 2015). In addition, Black administrators have experienced racism when a White colleague is offered a leadership position instead of a Black administrator when being considered to serve at a school serving predominately White students (Echols, 2006).

Social Capital. Administrators and teachers of color often do not have social capital that is typically developed through connections made when one is part of the majority. Social capital includes things such as (a) mentors, (b) financial support to cover the cost of advanced degrees, (c) funds for travel, (d) fiscal support via grants, and (e) professional memberships. When encountering social capital as a barrier, Black administrators may experience a sense of isolation (Echols, 2006). Echols (2006) goes on to posit Black administrators are often not recognized for their accomplishments as are their White peers. For example, a Black administrator and a White administrator may have outstanding professional backgrounds (e.g., conference presentations and/or awards) and the White administrator will receive recognition for his or her accomplishments while the accomplishments of the Black administrator go unacknowledged. 


\section{Current Research Base}

Extant research about the barriers Black educators encounter as they aspire to and navigate leadership roles in the PK-12 public school setting in the United States is limited. A review of the literature revealed six existing studies that explored the experiences of retired and or currently practicing Black administrators serving in the PK-12 public school setting in the United States. Those studies are described below in chronological order.

Bloom and Erlandson (2003) conducted a qualitative study using a naturalistic inquiry design with interviews as the data source. Participants in Bloom and Erlandson (2003), served in urban school settings, were identified by pseudonyms and referred to as Claire Broussard, Rose Atwell, and Grace Cleveland. Ms. Broussard was an assistant principal for nine years before being promoted to a principal position. According to the study, she had been in education for 35 years prior to retiring. The number of years she served as a principal was not specified. Rose Atwell was a teacher for 17 years prior to serving as a middle school principal for 20 years. Dr. Cleveland served as a teacher for 12 years prior to serving her remaining 17 years as an administrator. In this study, Bloom and Erlandson (2003) found administrators had the positive experiences of acting as advocates, role models, and change agents. Conversely, they also encountered barriers such as racism and sexism perpetrated by their colleagues and supervisors within their administrative tenure.

Through a qualitative study using interviews as the data source, Loder (2005) explored the experiences of administrators from Chicago Public Schools. Four Black female administrators, identified via pseudonyms, were the participants in this study. Mrs. O'Neal and Mrs. Alexander spent four decades as teachers and administrators. Next, Dr. Kent was a teacher and administrator from the late 1960s through the 1980s. Dr. Lowe was a teacher and 
administrator for 33 years. The study did not specifically state how long each participant served as an administrator. The results of Loder's (2005) research revealed Black administrators had the positive experiences of acting as advocates, role models, and segregate parents. Unfortunately, during their interviews, these administrators also recalled encountering barriers such as community, distrust, and the feeling of not being a valued part of their professional communities.

Brooks and Jean-Marie's (2007) ethnography, a qualitative study, was conducted in an urban high school in the southeastern region of the United States. The administrators included in this study were the principal, the assistant principal for curriculum, the dean of students, the athletic director, and several department chairs. Their years of experience as administrators were not stated. In this study, Brooks and Jean-Marie (2007) found Black administrators had positive experiences such as acting as advocates, mentors, and role models. Other findings indicated the administrators encountered barriers such as racism and stereotypical behavior.

Through interviews, Moore (2013) explored the experiences of Black female administrators, identified with pseudonyms, in suburban school settings in the mid-Atlantic United States. There were seven principals and 15 assistant principals across 10 elementary schools, five middle schools, and five secondary schools. These administrators had an average of 14 years of teaching experience. Eleven of these administrators had experience as department heads, 15 had experience as club advisors and seven had experiences as curriculum coordinators. Their years of experience as administrators were not specified. Moore's (2013) study revealed Black administrators had the positive experience of acting as advocates and role models while overcoming the barriers of (a) community, (b) racism, (c) stereotypical behavior, and (d) the "glass-ceiling" effect. 
Through a narrative inquiry, Henderson (2015) explored the experiences of six secondary administrators from Ohio Public Schools. Fred taught for six years prior to becoming a principal. At the time of the study he had been a principal for five years. Luther taught for eight years prior to becoming a principal. At the time of the study he had been a principal for five years. Marcus taught for eight years prior to becoming a principal. At the time of the study he had been a principal for seven years. At the time of the study James had been a principal for eight years. He taught for five years before assuming his role as a principal. At the time of the study, Keith had been a principal for 15 years after teaching for 15 years. Finally, at the time of the study Detrick had retired from teaching with five years' experience as a teacher and 30 years' experience as a principal. Henderson (2015) found Black administrators had positive experiences including acting as (a) advocates, (b) mentors, (c) segregate parents, (d) change agents, and (e) role models. Regrettably, Henderson (2015) found these administrators also endured the barriers of racism, community, and distrust.

Through an interview, Ononuju (2016) explored the experiences of an administrator who served in the urban high school setting for more than 20 years and still acted as a substitute administrator at the time the study was conducted. The subject of Ononuju's (2016) interview spoke of the positive experiences of acting as (a) an advocate, (b) a mentor, (c) a segregate parent, and (d) a change agent. Alas, he also encountered a feeling of his leadership abilities being "overlooked" by his superiors.

\section{Synthesized Findings of the Current Research}

Due to an educational debt, there exists an opportunity gap between BIaLS and their White peers. The experience of BIaLS and that of their White peers is dissimilar due to (a) disproportionate school discipline, (b) lack of access to gifted and talented programs, (c) lack of 
access to advanced placement (AP) and AP coursework in secondary grades, (d) lower academic achievement outcomes, and (e) overrepresentation in special education (Blanchett, 2006; Corra, Carter, \& Carter, 2011; Davis et al., 2019: Ford, 2014; Ford \& King, 2014; Grissom, \& Redding, 2016; Ladson-Billings, 2006; St. Mary et al., 2018; Vega et al., 2015; Miranda, 2015; Williams et al., 2002).

Significant factors contributing to the educational debt include a cultural mismatch in the teaching population as only $7 \%$ of teachers in the United States are Black (U.S. Department of Education, National Center for Education Statistics and OCR, 2016b) and a disproportionate number of Black administrators, 1 in 10 (U.S. Department of Education, 2018). In addition to being few in number, Black administrators encounter barriers as they navigate their leadership roles. The barriers include (a) fatigue and health issues, (b) a lack of professional development, (c) racism, and (d) a lack of social capital (Brubaker \& Coble, 2007; Echols, 2006; Henderson, 2015, Jean-Marie, 2013; Marshall, 2004; Wilkerson \& Wilson, 2017). Fortunately, Black administrators have also had positive experiences such as acting as (a) change agents, (b) role models, (c) advocates, (d) mentors, and (e) surrogate parents (Bloom \& Erlandson, 2003; Brooks \& Jean-Marie, 2007, Henderson, 2015; Loder, 2005; Moore, 2013; Ononuju, 2016).

Finally, research suggests CRP is a means to close the opportunity gap caused by the educational debt. Given this and the fact Black administrators have overcome barriers in their leadership roles and had positive experiences, it is unfortunate that the opportunity gap caused by educational debt is still so considerable. Current research that explores how perceived racial bias affects the abilities of Black administrators to create equitable learning environments is essential to add to the body of research that exists as the number of BIaLS served in the PK-12 public schools continues to grow. 


\section{Limitations of Current Research Base}

Limited research exists related to the experiences and barriers encountered by Black administrators in the PK-12 public school setting in the United States As previously stated, only six qualitative studies exist on this topic. There are no quantitative studies or studies utilizing a mixed methods design to explore the experiences of Black administrators. Further, within these studies the experiences of only approximately 45 Black administrators were explored. A study exploring the experiences of additional Black administrators would add to the body of research in order to better inform the field.

Further, current research leaves some questions unanswered. None of the current studies chose to explore the link between perceptions of racial or cultural issues and educational access and equity for Black educators. Currently, research fails to explore how racial bias affects the ability of Black administrators to create equitable learning environments for BIaLS. A study that relates to the experiences of Black administrators serving in the PK-12 public school setting in the United States and how barriers affect their ability to create equity through cultural responsiveness would make a significant addition to the body of existing research.

\section{Summary}

Extant research about the experiences of Black administrators is limited. First, the sample size of existing studies is insufficient. Future research exploring the experiences of additional Black administrators will lead to results more representative of experiences encountered across the United States. Further, qualitative methodology is used in all existing research. The introduction of studies utilizing mixed methods design will not only add to but diversify existing research about the experiences of Black administrators. Further, a study utilizing a mixed methods design will add quantitative data to explain the data collected via the qualitative sources 
typically used during educational research, thereby creating a robust and strong methodological study.

Finally, completing a study using a mixed methods design framed by a theoretical framework to explore the experiences of Black administrators as they attempt to create equity through a culturally responsive lens will make a significant, timely addition to the existing body of research. As the number of BIaLS served in the PK-12 public school setting in the United States continues to grow, cultural responsiveness becomes a necessary part of the educational environment. The experiences and barriers navigated by Black administrators must be recognized, explored, and addressed.

\section{Purpose of Study and Research Questions}

Given the limited amount of previous research on the experiences and barriers encountered by Black administrators in the PK-12 public school setting in the United States, additional research is needed to add to the body of research. In addition, little or no research exists on how those experiences and barriers preclude Black administrators from creating equitable learning opportunities through cultural responsiveness.

This study will be framed by Critical Race Theory (CRT) and the concept of community cultural wealth $(\mathrm{CCW})$ and seeks to answer five research questions.

1. What are the positive experiences of Black administrators in the PK-12 public school setting in the United States?

2. Which barriers are encountered by Black administrators in the PK-12 public school setting in the United States? 
3. To what extent do positive experiences help Black administrators in the PK-12 public school setting in the United States as they attempt to create equity through culturally responsive school policies and practices?

4. To what extent do barriers hinder Black administrators in the PK-12 public school setting in the United States as they attempt to create equity for BIaLS?

5. How does cultural capital affect the experiences of Black administrators in the PK-12 public school setting in the United States?

\section{Significance of the Study}

This study has the potential to add to the current research in many ways. First, only six studies related to the experiences of Black administrators in the PK-12 public school setting currently exist. The addition of further research will increase the very limited number of studies previously conducted. Second, all existing studies related to the experiences of Black administrators in the PK-12 public school setting are qualitative studies. A study using a mixed methods design will create a robust, methodological study to add to current research. Third, no research explores how perceived racial bias affects the abilities of Black administrators to create equitable learning environments. Finally, since the number of BIaLS served in the PK-12 public schools setting in the United States is rising, a study investigating how Black administrators use their leadership roles as a means for creating equity through culturally responsive schools initiatives will make a timely and significant contribution to research.

\section{Limitations/Delimitations}

This study seeks to explore the experiences and barriers encountered by Black administrators as they navigate their leadership roles for the purposes of creating equity through cultural responsiveness. It is important to outline the limitations of this study so readers can 
interpret the results with accuracy. First, this study explores the experiences of Black administrators serving in the PK-12 public school setting in the United States. Therefore, the results may not be generalized to administrators of other ethnic minorities (e.g., Asian, Pacific Islander, Latinx). Second, results may not be generalized to administrators serving in private school settings. Third, results may not be generalized to administrators serving in a higher education setting. Finally, results many not be generalized to administrators serving in settings outside of the United States.

\section{Definition of Terms}

BIaLS: Black, Indigenous, and Latinx students

Bias: inert and instinctive points of view and understanding as opposed to open and explicit racism (Kang, 2012)

Culturally relevant pedagogy: culturally relevant pedagogy has three criteria: (a) students must experience academic success; (b) students must develop and/or maintain cultural competence; and (c) students must develop a critical consciousness through which they challenge the status quo of the current social order (Ladson-Billings 2005)

Disproportionality: the overrepresentation or underrepresentation of a particular population or demographic group in an educational setting comparative to the presence of this group in the overall student population (Williams et al., 2017)

Educational Debt: The disparities in standardized test scores in the United States between Black and White students, Latinx and White students and immigrant and White students that has accumulated over time and is comprised of historical, economic, sociopolitical, and moral components (Ladson-Billings, 2006) 
Equity: a system where unequal assets are reorganized to produce structures and schools that share a greater chance of becoming more alike (Brayboy et al., 2007) Opportunity Gap: The deficiencies in the foundational components of societies, schools, and communities that produce significant differences in educational and socioeconomic outcomes (Darling-Hammond, 2013)

Racism: A system of dominance, power, and privilege that is rooted in the historical oppression of subordinate groups that the dominant group views as inferior, deviant, or undesirable. The dominant group creates or maintains structures and ideology that preserve their power and privilege while excluding subjugated groups form power status, and access to resources (Harrell, 2000)

Racial Inequality: The experience of missed opportunities by oppressed persons based on how people perceive and treat them through prejudice based on characteristics such as skin color, race or other physical characteristics, the individual's place of origin, or culture (Ford, 2014) 


\section{CHAPTER II: LITERATURE REVIEW}

There is limited research about the experiences of Black administrators in the PK-12 public school setting in the United States. Of the few studies that do exist, there are many facets of the Black administrators' experience yet to be explored. Specifically, there is limited research related to the experiences of and barriers encountered by Black educators as they aspire to and navigate their leadership roles. Further, existing research has not yet addressed barriers affecting the abilities of Black administrators to create equitable learning environments for BIaLS. A study that relates to the experiences of Black administrators serving in the PK-12 public school setting in the United States and how barriers affect their ability to create equitable learning experiences would make a significant addition to the body of existing research.

Previously, research has shown cultural perceptions and racial issues including racial bias have an impact on Black educators in administrative roles. Extant research also shows cultural responsiveness is significant in creating equitable learning environments for BIaLS. Therefore, to better understand the experience of the Black administrator this chapter will focus on six significant themes: (a) CRT, (b) CCW, (c) the educational inequities experienced by BIaLS (d) the causes of those inequities, (e) proposed solutions to those inequities, and (f) the experiences of Black administrators as they attempt to create equity through cultural responsiveness for BIaLS in the PK-12 public school setting in the United States.

\section{Theoretical Framework}

\section{Critical Race Theory}

A key argument of CRT is racism is a prolific, systemic, and foundational means of structuring society (Dixson, 2018; Sleeter, 2017; Solorzano \& Delgado Bernal, 2001). Since Ladson-Billings and Tate (1995) introduced an educational framework using CRT, has 
developed as a subfield in education and added to the legal scholarship related to CRT (Dixson, 2018; Dixon \& Rosseau, 2016). Ladson-Billings and Tate (1995) argued that, despite the fact race is a considerable element in education, there is a lack of scholarly inquiry regarding race in the field of education. As a result, they proposed CRT, originally established by legal scholars, should be used to investigate the role of race and racism in education. Further, Ladson-Billings and Tate (1995) (a) chronicled the intersection of race and property rights and how the construct of Whiteness as property had the potential to be used to understand inequities in education, and (b) argued education policies and practice in the United States contribute to inequitable educational experiences for BIaLS (Dixson, 2018).

CRT scholars in education think the study of race and racism and the examination of how inequities caused by racism remain must lead to the manifestation of social change (Dixson, 2018). Sleeter (2017) posits that CRT offers conceptual guides to explore how race and racism are perpetuated and have become systemic. Further, Sleeter (2017) suggested CRT can be used as a framework to investigate how the Whiteness of teacher preparatory programs could possibly be remedied. To date, scholars have used CRT as a lens for exploring culturally responsive practices in science (Wallace \& Brand, 2012), the experiences of a Black science teachers (Mensah, 2019), the beliefs of secondary social studies teachers (Martell \& Stevens, 2017), adult education programs (Schwartz, 2014), advocacy related to closing the achievement gaps affecting Latinx students (Aleman, 2009), and educational leadership practices related to disproportionate exclusionary discipline as it relates to Black students (Matthews et al., 2017).

\section{Summary}

CRT in education brings to focus the inequities that exist in the educational system in the PK-12 public school system in the United States. More specifically, CRT in education highlights 
how the intersection of race, racism, and Whiteness as property leads to inequitable learning experiences for BIaLS. Race and racism are barriers to Black educators attaining administrative roles. As Black administrators attempt to navigate their leadership roles as they work to create equitable learning experiences for BIaLS, they must overcome a myriad of barriers related to race and racism. The experiences of Black administrators currently serving in PK-12 public school settings in the United States can add to the limited body of knowledge related to the disparate experiences of Black educators in leadership roles, thus informing policy and practices around the equitable recruitment and retention of Black educational leaders.

\section{Community Cultural Wealth}

Yosso's (2005) CCW theory calls in to question the traditional understanding of cultural capital. The intent of the theory of community cultural wealth is to shift from the deficit lens through which marginalized groups, such as Black Americans, are viewed to a more positive perspective that considers the resources those from marginalized groups gain from their culturally rich backgrounds and experiences. The theory of $\mathrm{CCW}$ posits that through lived experiences that take place in communities of color, students of color bring knowledge and skills to the classroom.

Using CCW as a lens, Burciago and Kohli (2018) posit that the value of teachers of color often goes unnoticed. However, they can play a significant role in creating social justice in schools because they recognize the inequalities that exist in U.S. public schools. Rodela and Rodriguez-Mojica (2020) explored how Latinx administrators used their cultural capital to create equity for their students in ethnically diverse learning environments. The study found Latinx administrators were met with resistance in the White dominant environments. Further, their 
advocacy and ability to act as agents of change during their administrative tenure was challenged (Rodela \& Rodriguez-Mojica, 2020).

\section{Summary}

CCW shifts the focus from the deficit lens traditionally used to view BIaLS to a focus on the resources people of color glean from communities of color and are able to use as they enter the educational environment. More specifically, CCW brings to the foreground the many skills and resources people of color possess. The failure to recognize the power of cultural capital acts as a barrier to Black educators working to attain and navigate administrative roles. As Black administrators attempt to navigate their leadership roles as they work to create equitable learning experiences for BIaLS, they use their cultural capital to overcome barriers related to race and racism. The experiences of Black administrators currently serving in PK-12 public school settings in the United States as it relates to Yosso's (2005) six forms of cultural capital can add to the limited body of knowledge related to the disparate experiences of Black educators in leadership roles, also informing policy and practices around the equitable recruitment and retention of Black educational leaders.

\section{Inequitable Educational Experiences of BIaLS Through a Critical Lens}

Black, Indigenous and Latinx students have a long history of inequitable school experiences compared to their White peers. Disproportionate school discipline (Skiba et al., 2011; Skiba et al., 2002), lack of access to gifted and talented programs (Ford, 2014; Ford \& King, 2014; Grissom, \& Redding, 2016), lack of access to advanced placement (AP) and coursework in secondary grades (Corra et al., 2011; Davis et al., 2019;Vega, Moore \& Miranda, 2015), lower academic achievement outcomes (Ladson-Billings, 2006; St. Mary et al., 2018; Williams et al., 2002), and overrepresentation in special education (Blanchett, 2006; Dever et al., 
2016; Skiba et al. 2008; Skiba et al., 2005; Sullivan \& Bal, 2013) have been clear ways in which disparate treatment of BIaLS has been evidenced.

\section{School Discipline}

Black, Indigenous and Latinx students are subject to exclusionary discipline at a higher rate than their White peers. Discipline data for the last four decades has shown BIaLS have been subject to exclusionary discipline at two to three times the rate of their White peers (Skiba et al., 2002; Skiba et al., 2011). In addition, schools with high rates of exclusionary discipline have lower rates of academic achievement (American Psychological Association, 2006; Gion et al., 2018). According to the OCR at the U.S. Department of Education (2014), although Black students account for $16 \%$ of the student population they represent $40 \%$ of out of school suspensions. Likewise, Indigenous students make up $1 \%$ of the student population, but represent nearly $2 \%$ of out of school suspensions. Gion et al. (2018) found Indigenous students were overrepresented in office discipline referrals at the secondary level.

\section{Lack of Access}

Significant disparities exist when considering students in gifted education (Grissom \& Redding, 2016). Black students are less likely than White students to be identified for a gifted program even if they meet the indicators for inclusion (Ford, Grantham, \& Whiting, 2008a, 2008b). According to the OCR at the U.S. Department of Education (2014), although Black students account for $16 \%$ of the student population they make up less than $10 \%$ of students in gifted education. Taliaferro and DeCuir-Gunby (2008) suggest the disparity occurs because Black students are less likely to be recommended for AP courses by their teachers. Similarly, Hispanic students make up $25 \%$ of the student population, but represent only $18 \%$ of students in gifted education and Indigenous students make up 1\% of the student population but represent 
less than $1 \%$ of students in gifted education. In addition, Black students are less likely to attend a school with a gifted program. According to data from the Early Childhood Longitudinal Study, Kindergarten cohort $83 \%$ of Black students attend schools with a gifted program as compared to 90\% of White, $91 \%$ of Asian, and $93 \%$ of Hispanic students. This opportunity gap has the potential to limit future outcomes for BIaLS (Card \& Giuliano, 2014; Delcourt et al., 2007; Grissom \& Redding, 2016; Rogers, 2007).

Moreover, disparities in representation of Black students in AP courses are similar to those in gifted courses. There exists an opportunity gap for BIaLS in placement in AP courses (Taliaferro \& DeCuir-Gunby, 2008). According to the OCR at the U.S. Department of Education (2014), although Black students account for $16 \%$ of the student population they make up less than $10 \%$ of students in AP courses. Likewise, Hispanic students make up $25 \%$ of the student population, but represent only 19\% of students in AP courses and Indigenous students make up less than $1 \%$ of students in AP courses.

\section{Lower Academic Achievement}

Due to the educational debt, Black and Latinx students have earned less than average grades and have not met expectations on standardized assessments (Ladson-Billings, 2006; Williams et al., 2002). According to the NCES (2019a), The average National Assessment of Education Progress (NAEP) reading scale score for Black students was 26 points lower, the average reading scale score for Hispanic students was 23 points lower, and the average reading scale score for Indigenous students was 30 points lower than White students. Further, according to the NCES (2019b), the average National Assessment of Education Progress (NAEP) math scale score for Black students was 25 points lower, the average reading scale score for Hispanic 
students was 19 points lower, and the average reading scale score for Indigenous students was 21 points lower than White students.

Schools serving Black students (a) larger class sizes, (b) inferior curricula and facilities, (c) fewer funding sources, and (d) less qualified teachers (Condron et al., 2013; Rowley \& Wright, 2011). Black, Indigenous and Latinx students are tracked in lower ability groups and are retained at a higher rate than their White peers (Brayboy et al., 2007; Meece \& Kurtz-Costes, 2001). Historically, it has been difficult for BIaLS in the United States to receive an education equal to that of their White peers (Diemer et al., 2016; St. Mary et al., 2018; Wiggan, 2008). Racists policies and perceptions play a role in BIaLS lack of academic achievement (Blanchett, 2006; Brayboy et al., 2011; Kaomea, 2001; Thomas, 2004).

The inequities caused by the educational debt are numerous and include but are not limited to: (a) inadequate facilities; (b) inexperienced, substitute, or subpar teachers; and (c) low level curriculums or curriculums that do not mirror the experience of BIaLS (Brayboy et al., 2007; Casey, 2004; Ford, 2014; Ford \& King, 2014; McKown, 2013; Scott et al., 2018; TalbertJohnson, 2004). These inequities are barriers to BIaLS receiving educations that are equal to their peers (Casey, 2004; McKown, 2013; Rowley \& Wright, 2011; Scott et al.; 2018).

In addition to the lack of quality teachers and facilities, BIaLS are often expected to learn from a curriculum that does not draw from their experience. Curriculums presented to Black students are less rigorous focusing on low level skills required for standardized assessment which are often culturally and or linguistically biased (Brayboy et al., 2007). The focus on low level skills leads to few opportunities for genuine learning experiences. Curricular materials and content do not represent the lived experiences of BIaLS which makes it difficult for BIaLS to make connections that lead to learning (Bernal, 2002; Brayboy et al., 2007). 
Moreover, BIaLS are often taught by underprepared teachers. In fact, BIaLS are more likely to be taught by substitute teachers, or teachers who completed alternative certificate programs to obtain their educator licensure (Condron et al., 2013; Darling-Hammond, 2000; Talbert-Johnson, 2004). Despite the fact research indicates it is improbable students can recover from valuable instructional minutes received from novice underprepared teachers (Casey, 2004), schools that serve BIaLS are more likely to be staffed by less experienced teachers (Aud et al., 2010; Eubanks \& Weaver, 1999; Mickelson, 2001). According to the National Commission on Teaching and America’s Future (1996), nearly 30\% of newly hired teachers have temporary licensure, substitute licensure or lack any form of teacher licensure. To exacerbate the effects of inferior teaching, public schools in urban areas of the United States are often housed in facilities that are in disrepair and equipped with aged and or obsolete technology (Casey, 2004; Condron et al., 2013). The opportunity gap that exists between White students and BIaLS affects BIaLS socioeconomic status for a lifetime (Condron, et al., 2013; Johnson, 2006; Levin, 2009;

McKown, 2013; Oliver \& Shapiro, 2006; Reardon \& Robinson, 2007).

\section{Overrepresentation in Special Education}

Black, Indigenous and Latinx students are identified for special education at a higher rate than their White peers (Dever et. al, 2016; Skiba et al. 2008; Skiba, et al., 2005; Sullivan \& Bal, 2013). According to the OCR Statistics (2014), Black students represent $19 \%$ of students being served under the IDEA, although they account for only $16 \%$ of the students enrolled in public schools in the United States. According to Blanchett (2006), racism contributes to the disproportionate placement of Black students into special education programs as exhibited by (a) insufficient funding provided to schools serving students of color, (b) the use of culturally insensitive curricula, and (c) the placement of teachers who are underprepared to teach BIaLS. In 
addition, the limited access to resources in urban settings have led to Black students being misidentified for special education services (Talbert-Johnson, 2001, 2004).

\section{Summary}

Many factors contribute to the opportunity gap and educational debt owed to BIaLS including (a) exclusionary discipline, (b) lack of access to gifted education and AP courses, (c) lower academic achievement, and (d) disproportionate placement in special education. Extant research suggests culturally responsive pedagogy has a positive impact on disproportionate referrals for exclusionary discipline and placement in special education. In addition, culturally responsive curricula and learning environments are linked to higher academic achievement among BIaLS. Black administrators can address these inequitable experiences through the implementation of cultural responsiveness if provided with an environment in which barriers to their leadership roles are recognized and addressed.

\section{Hypothesized Causes of Educational Inequities for BIaLS}

\section{Institutional Racism}

Institutional racism describes the racial systems or structures in societal institutions meant to openly or secretly limit the rights or opportunities of certain racial or ethnic groups (Embrick et al., 2017) that go beyond individual acts through macrolevel interactions (Henderson et al., 2019). The different treatment of BIaLS is a form of institutional racism. For example, the disproportionate rate at which BIaLS are subjected to exclusionary discipline is an indicator of racism in the educational system at an institutional level (LaForett \& DeMarco, 2019). Policies that include exclusionary discipline are made to appear valid due to institutional racism (Henderson et al., 2019). In addition, institutional racism results in BIaLS attending under resourced schools. According to Moody (2016), institutional racism contributes to the under 
diagnosis of ADHD in Black students which may increase the possibility of them entering the School-to-Prison Pipeline. From a CRT lens, institutional racism exists and perpetuates educational policies and practices that contribute to inequitable learning experiences for BIaLS in a systemic way in education. Educators must be aware of how their unconscious beliefs, attitudes and lived experiences lead to them making a contribution to institutional racism as it relates to BIaLS (LaForett \& DeMarco, 2019).

\section{Whiteness}

Whiteness developed out of slavery and segregation wherein groups were given unequal access to citizenship, immigration, and property. Further, Whiteness is an ideology, not an identity, that is reinforced by colorblind principles both openly and institutionally without appearing to be related to race (Battey \& Leyva, 2016). Leonardo (2000) posits Whiteness is a racial dialogue, a social theory that gives advantage and privilege to those who are White.

Frankenberg (1993) and Roediger (1992) describe the major pieces of Whiteness as:( a) refusal to identify forms of racism, (b) choosing not to identity with a race or group, and (c) attempting to reference racism as a thing of the past, rather than the present.

Numerous White teachers become educators with little knowledge about racism and with a limited grasp on their own Whiteness (Ullucci \& Battey, 2011). In fact, Chubbock (2004) posits low academic achievement among Black students may be a result of White teachers' attitudes toward race that negatively affects their pedagogy and implementation of curriculum. According to Milner (2006), White teachers subconsciously view BIaLS as problematic which has a negative impact on the learning environment. When students that are more capable are the blueprint for what is considered the norm for White behavior, Whiteness is a factor. Further, when BIaLS are expected to express their emotions in undemonstrative, less passionate ways or 
the behavior of White students is viewed as more appropriate or desirable, Whiteness is a contributing factor (Battey \& Leyva, 2016).

According to Battey and Leyva (2016), Whiteness operates to determine how resources, employment and space are distributed through racially separated housing and the stratification of education and financial means. Lewis (2004) suggests while access to cultural capital and other resources may differ, all Whites have access to the symbolic capital of Whiteness. In addition, Lewis (2004) posits more knowledge about how Whiteness serves as a form of symbolic capital across different settings is important and calls for creative research approaches.

\section{White Dominant Norms}

According to Weilbacher (2012), White people and their agendas have historically and consciously dominated education in the United States from inception. A recent illustration of this dominance is the fact White corporate America profits significantly from the production of assessments, assessment materials, and digital education programs in use nationwide (Ravitch, 2010; Weilbacher, 2012). Bruce (2015) highlights White culture continues to dominate children's literature notwithstanding the increasing numbers of BIaLS. Further, a society in which White people have dominance and great influence makes it difficult for some to recognize White privilege.

Welch and Payne (2018) conducted a study applying the Minority Threaten Theory to frame a study about Latinx students' experiences with exclusionary discipline. Minority Threaten Theory posits more punitive social control policies and practices are implemented when there is a large number of BIaLS perceived as a threat to the racial and economic dominance of Whites. Welch and Payne (2012) hypothesized schools were more likely to use exclusionary discipline when there was a disproportionately large number of Latinx students. The hypothesis was 
supported as results of the study found the percent of Latinx students was significantly and positively related to the availability of exclusionary discipline. Welch and Payne (2018) posit the results of the study suggest that many forms of social control are enforced to depreciate those perceived as a threat to the dominant White majority. Several other studies describe multiple scenarios wherein BIaLS are discriminately subjected to different observation, searches, and investigations than their White peers (Lewis \& Diamond, 2015; Shedd, 2015).

Poteat and Spanierman (2012) investigated the effects of color-blindness on modern racism attitudes. Their findings support the idea that individuals in dominant groups adopt thinking that justifies their support for group hierarchies and their negative beliefs toward those they believe to be inferior. Poteat and Spanierman suggest interventions with dominant Whites should include the consideration of their denial of White privilege.

\section{White Teacher Bias}

Prior research states there is adequate evidence of a connection between teacher bias and achievement of BIaLS with Black students being more significant (Battle, 2017; McGrady \& Reynolds, 2013). It is not unusual for teacher bias to be reinforced in teacher preparation programs. (Allen et al., 2013; Howard, 2014; Miller, 2015; Nash \& Miller, 2015). Teacher bias plays a role in the disproportionate number of BIaLS in special education, exclusionary discipline, and gifted classes (Fergus, 2017).

According to Fergus (2016), there are three bias-based beliefs and expectations present in the school setting: (a) color-blindness, (b) deficit-thinking, and (c) poverty disciplining. Allen et al. (2013) posit because racial bias has the potential to unconsciously exist in teachers' perceptions, it is necessary for teachers to have tools to dismantle their lived experiences and historical background. These tools are necessary because teachers must recognize and keep their 
biases and microaggressions toward students in check to be culturally competent leaders in their classrooms (Allen et al., 2013; Sue et al., 2009).

Bonilla-Silva (2006) suggests the colorblindness ideology consists of: (a) omitting race, gender and other social identities as labels, (b) treating individuals as individuals without considering their social identities, and (c) concentrating on the similarities between individuals. Deficit-thinking is an ideology used within the field of education to provide an explanation for the lack of academic achievement due to deficiencies within a student or group of students (Valencia, 2010) whereas poverty-disciplining belief blames people of low socioeconomic status (SES) for their circumstance, but suggests changing their behavior to improve their income (Fergus, 2017).

\section{Lack of Cultural Competency}

Previous literature has substantiated the connection between cultural competence and successful outcomes for students (Robinson-Zanartu et al., 2011; Rogers \& Lopez, 2002). In a study conducted by Robinson-Zanartu et al. (2011) school psychologists reported the training and preparation they received was not adequate for them to exhibit cultural competence. In addition, there is a need for improved cultural competence among educators who find it difficult to teach diverse learners especially for students in racially segregated, under resourced schools (Chiu et al., 2017; Meaney et al., 2008). Despite the fact much research supports the significance of cultural competency, the needs of Indigenous students continue to be unmet in the educational environment (Hudiburg et al., 2015; Robinson-Zanartu et al., 2001).

Hudiburg et al. (2015) posit as the demographics of classrooms in the United States evolve, educators are tasked with meeting the needs of all students by the use of culturally competent teaching. Wachler and Troein (2003) describe cultural competency as learned skills 
that aide one in understanding cultural differences which leads to less difficulty in communication between people with different interpretations, understandings, or views. Further, cultural competence includes academic, interpersonal, clinical, and pedagogical ability that allows one to increase their appreciation of differences amid different ethnicities (Meaney et al., 2008; Wachler \& Troein, 2003). Castagno and Brayboy (2008) posit culturally responsive pedagogy requires teachers to have a certain level of cultural competence. Ladson-Billings (1994) recognized several attributes of culturally competent teachers: (a) acquiring a respect for cultural differences, (b) recognizing students from low SES are capable of being academically successful, and (c) becoming culturally sensitive by changing language or communication patterns.

\section{Summary}

Many factors are likely contributors to the inequitable learning experiences of BIaLS. These factors are: (a) institutional racism, (b) Whiteness, (c) White dominant norms, (d) White teacher bias, and (e) lack of cultural competency. It is not unreasonable to consider if these same factors act as barriers during Black administrators' tenure. Exploring the experiences of Black administrators currently serving in the PK-12 public school setting in the United States using mixed methodology will add to the limited extant body of qualitative research and create a new body of mixed methodology research relating to the disparate experience of the Black administrator.

\section{Proposed Solutions to Inequities}

\section{Improved Teacher Preparation for Cultural Responsiveness}

According to Mensah (2013) learning environments that increase academic achievement attempt to challenge the norm and support culturally relevant teaching and are a significant part 
of meeting the needs of culturally diverse students. Lenski et al. (2005) suggest pre-service teachers must be able to support students in thinking deeply about the role of culture in their own lives, to provide children with culturally relevant material and teaching, and to oppose the parts of school culture that invalidate students' cultural experiences. Sleeter (2001) posits pre-service programs employ two distinct paths to address the cultural differences between teachers and their students: (a) introduce more teachers who are from diverse communities or (b) attempt to form the beliefs and multicultural background knowledge of mostly White pre-service teachers.

Santamaria (2009), posits the most pandemic differences in the U.S. education system are cultural. According to Price-Dennis and Souto-Manning (2011), new teachers need experiences that will equip them to recognize the myriad of viewpoints found in the diverse student population present in classrooms. Therefore, more research is needed to explore how preservice teachers learn to become culturally responsive during their preparatory programs (Daniel, 2016; Hollins \& Guzman, 2005).

Kea and Trent (2013) conducted a mixed methods study exploring the experiences of 27 preservice teachers' ability to create and teach culturally responsive lessons. The researchers found that while culturally responsive instruction was included in the lessons plans assigned as part of the coursework, culturally responsive instruction was included in less than $25 \%$ of lessons observed during the preservice teachers' student teaching experiences. Kea and Trent suggest many opportunities to create and teach culturally responsively are required for preservice teachers. Further, they recommended restructuring preparatory teaching programs, redesigning curriculums, and including culturally responsive principles to outline the implementation of culturally responsive teaching in teacher preparatory curriculums including student teaching in diverse field-based experiences. 
Ziauddin and Ahn (2018) conducted interviews with preservice teachers and practicing teachers to explore their beliefs about culturally responsive teaching as a teaching framework. The participants suggested teachers need to: (a) change rigid views of cultural relevance, (b) be sure students' lived experiences are reflected in the curriculum, (c) create a culturally responsive learning environment, (d) use critical responsive pedagogy to reflect on themselves and their teaching practice, and (e) address barriers to the implementation of culturally responsive pedagogy. By conducting a case study of 15 White preservice teachers, Daniel (2016) found preservice teachers recognized and had questions related to teaching and learning as it related to culturally and linguistically diverse students, but had difficulty implementing culturally responsive teaching practices. Daniel suggested teacher educators must create pedagogies that cause preservice teachers to consider the specifics of how to implement culturally responsive pedagogy. Further, Daniel suggested preservice teachers might benefit from discussing what they noticed during their fieldwork and beginning to question their assumptions and identifying ways to become change agents during their teaching practice.

\section{Recruitment of Black Teachers}

As the diversity of the student population has grown in the United States, the same cannot be said for the teaching force. As a result, BIaLS often lack role models that look like and share the same experiences as them which contributes to the opportunity gap of BIaLS (Ingersoll \& May, 2011a). The recruitment of Black teachers is the first step in addressing the disproportionate number of White teachers in the U.S. PK-12 public education setting. Urban teacher preparatory programs are ideal environments to contribute to the recruitment and preparation of Black pre-service teachers (Farinde-Wu, 2018). 
In the 1980s, there was an increase in teacher salaries which led to the requirement of more education to meet teaching professional standards and increased rigor in teaching examinations which researchers suggest has been a barrier to the recruitment of Black teachers (Albers 2002; Goodman et al., 2008; Ingersoll \& May, 2011a; Madkins, 2011; McNeal \& Lawrence, 2009). Further, colleges and universities only actively recruit and or provide incentives to Black students when funds are available specifically for that purpose (Hood \& Parker, 1991; Villegas \& Lucas, 2005). A successful strategy to increase the number of Black teachers is to use a specific plan of action to attract and retain Black teachers (Scott, 2019). Unfortunately, colleges and universities oftentimes do not have protocols for reaching Black students (Hood \& Parker, 1991).

As community and junior colleges have historically enrolled approximately half of all Black students, this is a viable means to identify Black students for teacher preparation programs However, many Black students do not matriculate into four-year colleges and universities. To increase the likelihood of Black students entering into teacher preparation programs, colleges and universities can partner with community colleges to develop curriculums that meet requirements for entry into teacher preparation programs (Hudson et al., 2002; Villegas \& Lucas, 2005).

Finally, Black professionals already possessing a bachelor's degree can be recruited into the teaching profession via alternative routes to teaching certification (Chin \& Young, 2007). Several alternative programs have produced positive outcomes as it relates to identifying and retaining Black teachers (e.g. Boston Teacher Residency program, Call Me MISTER, Teacher Tomorrow in Oakland, Urban Teacher Enhancement Program) (Albert Shanker Institute, 2015; Bireda \& Chait, 2011; Ingersoll \& May, 2011b; Scott, 2019). 
Despite the effort to increase the recruitment and retention of Black teachers, the teaching force remains overwhelmingly White (Madkins, 2011). Scott (2019) posits colleges and universities should diversify their college of education faculty with those that are eager to recruit and mentor Black students in teacher preparatory programs. In addition, research suggests policies that encourage the recruitment and retention of Black teachers be put into place at both state and federal levels (Ingersoll \& May, 2011a; Madkins 2011). Madkins (2011) posits policy makers must establish new nontraditional programs to target Black teachers to increase the number of Black teachers.

In the end, Ingersoll and May (2011b) point to the need to increase recruitment of Black educators and recommend paying attention to circumstances that cause Black educators to leave the profession (2011a, 2011b). In fact, Ingersoll and May (2011a, 2011b) suggest simultaneously considering and addressing retention and recruitment of Black educators.

\section{Black Educational Leadership Opportunities}

\section{Creating Equal Access to Leadership Roles for Black Educators}

Black leaders represent approximately $10 \%$ of principals in the United States according to the NCES (2016c). A review of the literature revealed a plethora of barriers encountered by Black educators as they aspire to roles in educational leadership. Some of these barriers include community, distrust, racism, and stereotypes (Bloom \& Erlandson, 2003; Brooks \& Jean-Marie, 2007, Henderson, 2015; Loder, 2005; Moore, 2013).

To create equal access, leadership preparatory programs must recognize the past and present role of race in the United States and within the field of educational leadership. Recognition of the role of race will contradict the notion that Black educational leaders can only lead in schools where most of the student population is Black (McCray et al., 2007). Black 
educators should be given the opportunity to lead within any school. The location of a school or the racial demographics of the student body should not determine a Black administrator's placement. Black educators should have the same access to leadership positions as their peers.

\section{Creating Positive Experiences for Black Educators in Leadership Roles}

Black administrators overcome numerous barriers as they navigate their leadership roles. It is paramount that preparatory programs prepare future Black leaders with theoretical knowledge and pragmatic experiences that prepare them to be effective (Brown, 2005; Henderson, 2015). Additionally, Black educators aspiring to leadership roles must be given the opportunity to address race and racism within their coursework as they prepare for leadership positions (Boske, 2010).

Black educators aspiring to leadership roles must possess the skills to recognize, acknowledge and address how race and racism affects their ability to create an equitable learning environment. Future leaders need to be prepared to address race and racism through social justice and equity (Boske, 2010). The academic, social, and emotional needs of every student must be met through culturally responsive learning environments that take into consideration each students background and culture related experiences (Ladson-Billings, 1995).

In addition, future educators must be prepared to initiate difficult conversations and dialogues (Brooks \& Jean-Marie, 2007). Meaningful dialogue between Black administrators and their faculty and staff is critical. These conversations play a significant role in addressing stereotypical behavior, race, and racism as these issues negatively affect the provision of equitable learning environments.

As Black administrators work to overcome barriers to realizing their leadership roles, the time dedicated to the academic components of their administrative position diminishes. Black 
administrators described being responsible for most of the disciplinary actions taken in their buildings. Further, they recalled being expected to handle race related issues (Moore, 2013). These responsibilities require time that could be spent supporting students academically. Therefore, to create positive experiences for Black administrators providing additional resources to offer students support may be required (Henderson, 2015). Increased staff dedicated to social services, counseling support, behavioral health, and parent outreach will allow Black administrators to simultaneously provide needed student support and focus on instructional leadership.

\section{Summary}

Improving pre-service teachers' cultural responsiveness, recruiting more Black educators and increasing the number of leadership opportunities for them are all viable means to address the educational inequities that currently exist for BIaLS. In addition, increased cultural responsiveness for pre-service teachers will leave them better prepared to enter classrooms with BIaLS. Higher numbers of Black educators will also add to culturally responsive teaching environments as they have similar lived experiences as BIaLS.

\section{Why There Are So Few Black Administrators}

Black educators must overcome barriers to ascend to or sustain leadership positions. A review of the limited existing literature revealed a myriad of barriers a qualified educator must overcome based solely on the fact that he or she is Black and also outlined areas of success. To date, only six studies have examined the experiences of Black PK-12 leaders (i.e., Bloom \& Erlandson, 2003; Brooks \& Jean-Marie, 2007; Henderson, 2015; Loder, 2005; Moore, 2013; Ononuju, 2016) which included only approximately 45 total voices. Through their interviews, however, these Black principals, assistant principals, deans of students, athletic directors, 
department chairs, and teacher leaders described barriers they have encountered and successes they have experienced while attempting to navigate their leadership roles.

\section{Barriers}

\section{Community}

Community is operationally defined as a group of people living or working in the same place or having certain characteristics in common and emerged as a trend among Black educators in leadership positions as four of the six studies described community as a barrier for Black administrators. The nine principals from CPS and OPS described encountering barriers within their communities (Henderson, 2015; Loder, 2005). The six principals from Ohio reported race had a negative impact on their interactions with diverse staff and community members (Henderson, 2015). The three principals from Chicago described community members making intentional efforts to undermine their authority as educational leaders (Loder, 2005). One principal, there assistant principals, and one dean in an urban high school in the southeastern United States spoke of a "conspiracy of silence" wherein Black and White administrators did not acknowledge or discuss race or class issues (Brooks \& Jean-Marie, 2007). Luther, a principal in OPS for eight years at the time of the study, spoke of the difficulty of gaining parental involvement due to a large number of students from single-family homes (Henderson, 2015). Mrs. Alexander, an administrator in the 1980s and 1990s and now retired, described a lack of support from parents despite the fact something was done in the best interest of students (Loder, 2005). Ms. Lewis, and assistant principal in a suburban high school in the mid-Atlantic United States, recalled being left out of important administrative discussions (Moore, 2013). 


\section{Distrust}

Distrust is operationally defined as doubt, cynicism, or suspicion of another and emerged as a trend among Black educators in leadership positions. Black administrators from urban settings encountered distrust as they navigated their leadership roles (Brooks \& Jean-Marie, 2003; Loder, 2005). Black administrators in an urban high school in the southeastern United States described a "leadership lynch mob" wherein White administrators were not supportive of their Black colleagues or Black students. Ms. Marshall, an administrator who served in CPS for 35 years, spoke of administrators' authority being sabotaged by parents and community members (Loder, 2005). Keith, a principal in OPS for 15 years at the time of the study, spoke about White parents exhibiting a distrust of him for fear he may be flirtatious with female students (Henderson, 2015). Administrators encountered distrust in different ways, but three of the six studies described a lack of trust as a barrier encountered by Black administrators.

\section{Race and Racism}

A review of the literature revealed a trend of race related issues and racism as a barrier encountered by Black administrators. Black administrators from urban and suburban districts reported encountering similar barriers related to race and racism (Bloom \& Erlandson, 2003; Henderson, 2015; Moore, 2013). Derrick, a principal in OPS for five years at the time of the study, mentioned the perception that Black male principals lacked the skill required to be a good leader (Henderson, 2015). Three principals from suburban high schools and middle schools reported experiencing racism (Bloom \& Erlandson, 2003). Ms. Davidson, an assistant principal in the mid-Atlantic United States, reported White teachers saying things like "They should have manners" when talking about Black students (Moore, 2013). Black administrators in an urban high school in the southeastern United States recalled White administrators attributing low test 
scores Black students received on achievement exams a result of the Black students not caring. A White teacher described Black students as having "ghetto values" (Brooks \& Jean-Marie, 2007). Administrators experienced race and racism as barriers in many different scenarios, but four of the six studies described Black administrators navigating race and racism as part of their leadership roles.

\section{Stereotypes}

A trend of stereotypical behavior emerged as a barrier for Black administrators in leadership roles. Helen Mason and Lisa Walker, assistant principals in a suburban elementary school in the mid-Atlantic United States, described their colleagues' belief that they were the only administrators able to discipline Black students (Moore, 2013). Black administrators in an urban high school in the southeastern United States reported White administrators in the building held the belief that the attitudes of Black students and their families would prevent Black students from achieving academic success (Brooks \& Jean-Marie, 2003). Fred, a principal in OPS for six years at the time of the study, spoke about "How hostile the environment can become, not just in education, but any workplace with African Americans" due to stereotypes. Keith and Derrick, principals in OPS for 15 and five years respectively described a stereotype of Black males' inability to communicate well with individuals of other ethnicities and a propensity to "take it easy" on Black students when addressing disciplinary issues (Henderson, 2015).

Administrators encountered stereotypical behavior under varying circumstances, but three of the six studies described Black administrators navigating the stigma of stereotypes as part of their leadership roles. 


\section{Other Barriers}

A review of the literature revealed additional barriers encountered by Black educators in leadership roles (Bloom \& Erlandson, 2003; Brooks \& Jean-Marie, 2003; Loder, 2005; Moore, 2013; Ononuju, 2016). Claire Broussard, an educator and administrator in an urban school district, described politics and the desire of district level administrators to not support real change, but instead wishing to maintain the status quo. Rose Atwell, a principal in an urban setting, recalled experiencing sexism in the form of male teachers filing unsubstantiated grievances (Bloom \& Erlandson, 2003). The three principals from CPS recalled feeling as if education was not valued during their tenures as administrators (Loder, 2005). The seven principals and 15 assistant principals in suburban elementary, middle and secondary schools reported experiencing the "glass-ceiling" effect (Moore, 2013). One principal from an urban high school in northern California reported feeling as if his ability to have a positive impact on building systems, such as curriculum, was overlooked (Ononuju, 2016).

\section{Successes}

\section{Advocacy}

Student advocacy is operationally defined as one who supports and or defends students and emerged as a theme related to the experience of Black educators in leadership roles. Participants in all six studies described Black administrators advocating for students. The form of advocacy varied, but administrators viewed student advocacy as a significant part of their leadership roles. Black administrators serving in suburban high schools and middle schools described their roles as student advocates. Claire Broussard, a principal in a suburban high school, described having conversations with students about their educational goals. In addition, she created new programs such as auto mechanics and construction in her building to expose 
students to vocational skills and opportunities. Rose Atwell, a middle school principal in an urban setting, utilized servant leadership to advocate for her students (Bloom \& Erlandson, 2003). Ms. Willis, an administrator in a suburban elementary school, advocated for equity in learning for all students (Moore, 2013).

Mr. Blackshire, a retired school principal who still worked as a substitute administrator in an urban area in northern California, shared his belief that educators must do everything they can to help students achieve success. He described identifying ways to overcome challenges and “doing something different". He also recalled giving the students what they wanted: more Black teachers and administrators (Ononuju, 2016). Marcus, a principal in OPS, described advocating for Black male students for whom standards were lowered or who were prematurely placed in special education classrooms (Henderson, 2015).

Similarly, principals and assistant principals in suburban elementary, middle and secondary schools reported actively supporting the educational advancement of ethnically diverse students. An assistant principal in a racially mixed elementary school advocated for Black students when she recognized a disparity in discipline - Black students were receiving harsher consequences than White students for similar behavioral infractions (Moore, 2015). Principals, assistant principals, deans, athletic directors, department chairs, and teacher leaders in an urban high school in the southeastern United States described working as advocates for their peers in Black leadership in addition to their students. For example, these administrators would share information about scholarship opportunities, tutoring, and other supports available to students most of whom were struggling academically (Brooks \& Jean-Marie, 2003). 


\section{Mentoring}

Mentoring is operationally defined as teaching, guiding and or advising and emerged as a theme related to the experiences of Black educators in leadership roles serving in the secondary setting. Principals, assistant principals, deans, athletic directors, department chairs, and teacher leaders in urban high schools described providing mentorship for the student body, especially those students from ethnically diverse backgrounds (Brooks \& Jean-Marie, 2003). A Black administrator in an urban high school in the southeastern United States mentored Black teachers into leadership roles (Brooks \& Jean Marie, 2003). A retired principal from an urban high school in northern California, Mr. Blackshire, reported acting as a mentor for both students and other Black educators and leaders within the building. Mr. Blackshire was able to gain the trust of students who then followed his lead. He also provided Black educators who aspired to be administrators with an opportunity to work within his school (Ononuju, 2016).

Ms. Lewis, an assistant principal in a suburban high school, described meeting with Black students to encourage them to enroll in advanced placement classes to be prepared for college. Ms. Davidson, an assistant principal at a racially mixed middle school, and Ms. Willis, a principal at an elementary school serving mostly White students, shared stories of their mentorship of teachers as they learned to support Black students in their classrooms (Moore, 2013).

Dr. Lowe, a principal in an urban school, mentored both her students and their parents. She described supporting the young parents of her students and the students (Loder, 2005). Fred, a principal in OPS, acted as a mentor for male students by supporting them as they matured into manhood. All six administrators involved in the study conducted in OPS discussed their identity as role models. Luther, who had been a principal for eight years at the time of the study, stated 
his leadership practices were based on "being a role model and leading by example" (Henderson, 2015). While the form of mentorship varied, participants in five of the six studies described Black administrators advocating for students.

\section{Parenting}

Parenting is operationally defined as acting as a role model, mother or father figure and emerged as a theme related to the experiences of Black administrators. While the characteristics of parenting varied, researchers in three of the six studies found that some form of parenting existed as Black administrators navigated their roles as leaders.

Three principals from CPS, Mrs. O'Neal's, Dr. Kent's, and Dr. Lowe's, definition of leadership encompassed loving, nurturing, and guiding their students. Each described their role as acting as surrogate parents to their students. In addition, the principals recounted being given maternal authority as part of their leadership roles. Mrs. O'Neal described her motherly love and concern for her students. Dr. Lowe recalled mothering her students and their young parents (Loder, 2005).

Similarly, paternalism emerged as a theme for the six principals in the OPS. The six principals reported a feeling of paternal affinity for their students, especially Black students in their buildings. They reported acting as father figures to their students. Marcus, who had been a principal for eight years at the time of the study, spoke about paternal endearments students used to address him. He described students considering him a member of their families (Henderson, 2015). Students affectionately referred to Mr. Blackshire, a retired administrator form northern California, as "The Godfather" (Ononuju, 2016). 


\section{Realizing Change}

Realizing change is operationally defined as casting a vision of transformation to create an equitable learning environment and emerged as a theme related to the experiences of Black administrators serving in various settings. Claire Broussard, a principal in a suburban high school, described the beginning of her tenure as challenging. She reported there was a culture and climate of helplessness and hopelessness. Several principals had short tenures in the building before leaving within the last several years. The graduation rate was $2 \%$ to $5 \%$ and the building was is in disrepair. A few weeks before school was to start, there were 16 teaching vacancies to be filled. Within the first two years in her administrative tenure she was able to improve attendance rates and increase academic achievement (Bloom \& Erlandson, 2003).

Keith, an administrator in OPS for 15 years at the time of the study, described gaining the trust of the community by showing them he genuinely cared about the students (Henderson, 2015). Mr. Blackshire, a retired principal from northern California, recalled he would "make things change, make systems change" (Ononuju, 2016). Leslie Lewis, an assistant principal in a suburban high school in the mid-Atlantic United States, reported using her leadership role to address the lack of diversity in the faculty. In addition, Ms. Harris, an assistant principal in a suburban elementary school in the mid-Atlantic United States, recalled leading the charge to teach educators in her building to better serve Black students (Moore, 2013). Participants in three

of the six studies described themselves as change agents. The actions they took to realize change differed, but these administrators viewed realizing change necessary as they navigated their leadership roles. 


\section{Role Models}

A role model is operationally defined as a person who acts as an exemplar or good example. Acting as a role model emerged as a trend among Black educators in leadership positions as three of the six studies identified described Black administrators acting in this capacity. Black administrators from an urban district in the southeastern United States found it important to present a professional image to be a role model for their students (Brooks \& JeanMarie, 2007). Rose Atwell, an administrator in an urban middle school, spoke about working just as hard as her staff to model hard work (Bloom \& Erlandson, 2003). Marcus, an administrator for eight years in OPS at the time of the study, described modeling strong leadership and decision-making skills for his students. Fred's experience, an administrator for six years in OPS at the time of the study, paralleled the experience of Marcus as he described modeling selfrespect for his students (Henderson, 2015).

\section{Summary}

The disproportionate number of Black administrators remains as their experience is disparate than those of their peers. More specifically, Black administrators encounter numerous barriers as they navigate their leadership roles. Those barriers include: (a) community, (b) distrust, (c) race and racism, (d) stereotypes, and (e) others including lack of support from district level administrators, sexism, and a "glass-ceiling" effect.

Black administrators have, despite these barriers, continued a culture of excellence in educational leadership. The positive experiences of Black administrators include: (a) advocacy, (b) mentoring, (c) parenting, (d) realizing change, and (e) acting as role models for both educators and students. Further exploration of the experiences of Black administrators will add to 
the limited body of knowledge as it relates to Black administrators in the PK-12 public school setting in the United States as they work to create equitable learning experiences for BIaLS. 


\section{CHAPTER III: METHODS}

\section{Mixed Methods Design}

I used a mixed methodology in this study. Studies using mixed methods designs originated in the 1980s. Researchers in the field of social sciences, education, and health sciences began using a mixed methodology to conduct studies during that time. Today, mixed methods research designs are gaining popularity as research questions require answers beyond siloed approaches to methodological research designs.

The purpose of qualitative, open-ended, research methods is to gather and interpret words to understand humans' social patterns while the purpose of quantitative, closed-ended, research is to gather numbers to describe or identify social patterns using deductive logic (Creswell, 2014; Greene et al., 1989; Hesse-Biber, 2010; Salehi \& Golafshani, 2010). Mixed methods research consists of the use of at least one qualitative and one quantitative research element to complete complicated inquiries (Caruth, 2013; Greene et al., 1989; Heyvaert et al., 2013; Johnson et al., 2007; Pluye \& Hong, 2014; Schoonenboom \& Johnson, 2017). Mixed methods research merges the strength of qualitative and quantitative research methods (Caruth 2013; Johnson, et al., 2007; Pluye \& Hong, 2014). Qualitative research methods provide different ways to explore and interpret data (Polit \& Beck, 2006). This exploration helps researchers understand and explain events and occurrences (Creswell \& Garrett, 2008). Quantitative methods are used to produce broad conclusions or results (Neuman, 2000; Rocco et al., 2003) and help researchers describe and establish patterns using deductive logic (Creswell \& Garrett, 2008).

\section{Transformative Explanatory Sequential Design}

I used a transformative explanatory sequential mixed methods design. In the first phase of the study, I used an online survey to collect quantitative data. The survey was distributed via 
email and social media and remained open for 35 days. In the second phase of the study, I used semi-structured interviews to explain the quantitative data collected during the initial phase of the study. Miles et al. (2020) posit both qualitative and quantitative data are necessary for understanding. Further, previous literature suggests the linking of quantitative and qualitative data is useful for explanatory purposes and creates a very strong combination of data (Miles et al., 2020). The use of a mixed methods research design required an extensive amount of work and familiarity with the collection of both quantitative and qualitative data. Ultimately, the use of a mixed methods research design created a more robust, methodologically strong study.

I framed this mixed methods research study by exploring how the intersection of education, race, and racism affect the experiences of Black administrators as they work to create equitable learning experiences for BIaLS. I also used the theory of CCW to explore how cultural capital affects the experience of Black administrators as they work to create culturally responsive practices and policies. The objective of the study was to explore the experiences of Black administrators serving in the PK-12 public school setting in the United States and how those experiences affect their ability to lead and to serve as change agents in their respective roles as it pertains specifically to creating cultures of equity and cultural competence. Appendix A depicts how CCW and CRT were used to frame the study.

The transformative paradigm is a response to historically marginalized individuals seeking ways to give voice to their experiences in the field of research. The transformative paradigm allows those who have been marginalized to partner with and guide researchers to bring recognition to their plight in hopes of increasing social justice (Merten, 2009). More specifically, according to Merten (2009) when theoretical perspectives such as CCW and CRT are used to frame research a well-designed study can highlight the positive features, strengths, 
and acts of opposition required to bring social change. Further, Merten (2009) posits the rationale for transformative paradigm is grounded in: (a) continuing obstacles to social equity in society worldwide, (b) the need to recognize matters of power, discrimination, and oppression can play a significant role in rectifying inequities, and (c) sympathetic confirmation from research of the possibility of social change when researchers work within the premise of transformative paradigm. This study used the theories of CCW and CRT as a lens to explore how the social inequities experienced by BIaLS can be addressed by Black administrators as they work to create equitable learning opportunities.

This study used a transformative explanatory sequential design (Creswell, 2014). The transformative design incorporates the convergent, explanatory, exploratory, or embedded designs within a social justice framework (Caruth 2013; Creswell, 2014). The theories, in this case CCW and CRT, frame various facets of the study such as the research problem, the research questions, the data collection and analysis, and the call to action. The transformative design is often used to study marginalized groups such as citizens of third world countries, indigenous populations, females, individuals with disabilities, and racial and ethnic groups (Creswell, 2014). Explanatory sequential designs first collect quantitative data then qualitative data to compliment the quantitative findings. This design for my study is explanatory because qualitative data are used to explain the quantitative findings. It is sequential because the qualitative phase occurs after the quantitative phase (Caruth, 2013; Creswell, 2014). This design is often used in disciplines, such as education, in which quantitative research methods are more often used than qualitative research methods. In this design, the explanation of the quantitative data provided by the qualitative data provides a more robust research study than a study that relies solely on the collection of quantitative data (Creswell, 2014). 
In the first phase of this study, I collected quantitative data on the experiences of Black administrators serving in the PK-12 public school setting in the United States through the use of a survey. After I analyzed the quantitative data collected, the second, qualitative, phase was conducted through semi-structed interviews. The interview questions were informed by the quantitative data collected from the survey in the first, quantitative, phase. In addition, the second qualitative phase provided a deeper understanding of the experiences of Black administrators serving in the PK-12 public school setting in the United States. A diagram of the design is depicted in Appendix B. Hodgkin (2008) used a transformative explanatory sequential design with a feminist framework to explore the social capital of men and women living in a city in Australia. Buck et al. (2009) used an explanatory sequential design to study interest in science of African American girls' of low SES.

\section{Challenges}

First, the quantitative data source of this study was a survey. Surveys often have low response rates when the number of surveys disseminated is compared to the number of surveys returned (Couper, 2000; Mertens, 2009). To promote optimal participation in the survey, I distributed the survey electronically to participants identified through three social media groups with high membership representation of Black educators. A reminder to complete the survey was sent seven days after the initial distribution of the survey. Second, because I disseminated the survey nationally and because the qualitative phase of the study consisted of interviews, inperson interviews were impractical. In lieu of in-person interviews, I conducted interviews via video conferencing software at a time convenient for the interviewee. 


\section{Participants}

Participants included formal administrators such as deans, assistant principals, principals, associate principals, and district administrators from the elementary, middle school and secondary public school settings with one or more years of administrative experience. Invitations to participate in the quantitative phase of the study occurred in a variety of ways. First, social media was utilized to target three specific groups that are comprised of a high representation of Black educators, with all groups totaling a combined membership of approximately 17,000. The social media groups were Black Educators Rock, PhinisheD/FinishED (Drs/Future Drs) \#WhoGotNext, and Doctoral Mom Group.

In addition, invitations were sent via email and social media to Black administrators across the United States Participants were limited to Black educators who are currently or who have previously occupied leadership roles in the PK-12 public school setting in the United States within the last 20 years. The post included an explanation of the study and a link to the survey with embedded consent information.

The sample consisted of $42(\mathrm{~N}=42)$ respondents. Sixty-five survey responses were received. However, 23 were incomplete. I analyzed only the data collected from the 42 complete responses.

\section{Demographic Data}

Demographic data was collected about each respondent. In addition, demographic data was collected about each respondent's school district. The demographic data described in Table 1 below provide details about the participants in the study. The demographic data described in Table 2 provide details about the educational environment(s) from which each administrator drew his or her experiences and context for the data gathered from the study. 
Table 1

Demographic Data of Survey Respondents

\begin{tabular}{lll}
\hline & $\mathrm{n}$ & $\%$ \\
\hline Gender & 34 & 81 \\
Female & 8 & 19 \\
Male & & \\
Position & 2 & 5 \\
Dean & 22 & 55 \\
Assistant Principal & 1 & 0.5 \\
Associate Principal & 16 & 38 \\
Principal & 0 & 0 \\
Director & 1 & 0.5 \\
District & 0 & 0 \\
Assistant Superintendent & 0 & 0 \\
Superintendent & & \\
Years of Experience & 14 & 33 \\
$0-5$ & 21 & 50 \\
6-10 & 4 & 10 \\
$11-15$ & 3 & 7 \\
16 or more & &
\end{tabular}

\section{Instruments}

\section{Survey}

Quantitative data related to how Black administrators' professional experiences are affected by the intersections of education, race, and racism and the six forms of cultural capital was collected via a survey that consisted of both demographic, scaled, and open-ended questions. The survey is provided in Appendix C.

The survey used to collect quantitative data in the first phase of the study consisted of a total of 30 questions. Ten of the questions were multiple choice questions. Eighteen of the questions required a Likert scale response. Finally, two open ended questions allowed the respondent to provide a response in narrative form. I built the survey in Qualtrics. The survey 
was then reviewed by the three members of my dissertation committee. Then, I modified and improved the survey based on feedback from the committee members prior to distributing it.

Table 2

Demographic Data of Survey Respondents' Schools

\begin{tabular}{|c|c|c|}
\hline & $\mathrm{n}$ & $\%$ \\
\hline \multicolumn{3}{|l|}{ Grade Level } \\
\hline Early Childhood & 0 & 0 \\
\hline Elementary & 19 & 45 \\
\hline Middle & 7 & 17 \\
\hline Secondary & 15 & 36 \\
\hline \multicolumn{3}{|l|}{ Locale } \\
\hline Urban & 33 & 79 \\
\hline Suburban & 5 & 12 \\
\hline Rural & 4 & 10 \\
\hline \multicolumn{3}{|l|}{ Size } \\
\hline Small & 12 & 29 \\
\hline Medium & 4 & 10 \\
\hline Large & 26 & 62 \\
\hline \multicolumn{3}{|l|}{ Student Race } \\
\hline White $0-24 \%$ & 20 & 48 \\
\hline White $25-49 \%$ & 14 & 33 \\
\hline White $50-74 \%$ & 7 & 17 \\
\hline White $75-100 \%$ & 1 & 0.5 \\
\hline Black 0-24\% & 4 & 10 \\
\hline Black $25-49 \%$ & 18 & 43 \\
\hline Black 50-74\% & 18 & 43 \\
\hline Black 75-100\% & 11 & 26 \\
\hline \multicolumn{3}{|l|}{ Teacher Race } \\
\hline White $0-24 \%$ & 8 & 19 \\
\hline White $25-49 \%$ & 2 & 4 \\
\hline White $50-74 \%$ & 43 & 18 \\
\hline White $75-100 \%$ & 14 & 33 \\
\hline Black 0-24\% & 20 & 48 \\
\hline Black 25-49\% & 15 & 36 \\
\hline Black 50-74\% & 3 & 8 \\
\hline Black 75-100\% & 4 & 10 \\
\hline
\end{tabular}


The survey included ten multiple-choice items. The first six multiple choice questions addressed the respondents' grade level, administrative role, years of experience, gender, and the locale and size of the school district in which the respondent served. The four remaining multiple choice questions related to demographic data about the respondents' school district. The demographic data included the percentage of White students and teachers and the percentage of Black students and teachers in each school district. I inquired about this specific demographic data because I was interested in how the intersection of education, race, and racism affect the experiences of Black administrators as they work to create equitable learning experiences for BIaLS.

Likert scale items were developed to examine CCW. The Likert scale response options were: (a) very true of me, (b) true of me, (c) somewhat true of me, (d) neutral, (e) somewhat untrue of me, (f) untrue of me, and (g) very untrue of me. The eighteen Likert scale responses collected data about the respondents' perception about his or her cultural capital as it relates to Yosso's (2005) forms of capital. Yosso's (2005) forms of cultural capital are: (a) aspirational, (b) familial, (c) linguistic, (d) navigational, (e) resistant, and (f) social. I created three questions related to each form of capital. Each of the three questions provided data about to what extent each participant believed he or she possessed that form of social capital. Each survey item and the related form of capital is shown in Table 3 .

Respondents were asked to provide data related to what extent he or she possessed each of the six forms of cultural capital. There were seven response options. The response options were: (a) very true of me (b) true of me, (c) somewhat true of me, (d) neutral, (e) somewhat untrue of me, (f) untrue of me, or (g) very untrue of me. 
Table 3

Survey Response Items by Form of Community Cultural Wealth

\begin{tabular}{|c|c|}
\hline Form of Capital & Survey Items \\
\hline Aspirational & $\begin{array}{l}\text { I have succeeded as an administrator despite barriers to my success. } \\
\text { I am confident in my ability to work through conflicts in my school } \\
\text { district. } \\
\text { I do not allow racism or stereotypes to negatively affect my aspirations }\end{array}$ \\
\hline Familial & $\begin{array}{l}\text { Support from my family has facilitated my success as an administrator } \\
\text { My family members acknowledge and celebrate my professional } \\
\text { accomplishments. } \\
\text { My family members are empathetic when my professional } \\
\text { responsibilities extend beyond the school day. }\end{array}$ \\
\hline Linguistic & $\begin{array}{l}\text { My dialect is honored in my professional community. } \\
\text { Code switching is not necessary for my communications skills to be } \\
\text { validated. } \\
\text { My linguistic roots connect me with students, families and community } \\
\text { members. }\end{array}$ \\
\hline Navigational & $\begin{array}{l}\text { I know how to find resources to help me succeed. } \\
\text { I am confident in my ability to network within and/or outside my } \\
\text { school district. } \\
\text { I am provided with adequate resources to help my staff and students } \\
\text { succeed. }\end{array}$ \\
\hline Resistant & $\begin{array}{l}\text { I believe one of my roles is to address racial/ethnic injustices in my } \\
\text { school/district. } \\
\text { I believe part of my role is to make a difference in my school } \\
\text { community and broader society. } \\
\text { I believe education should serve to address the problem of racism in } \\
\text { our society. }\end{array}$ \\
\hline Social & $\begin{array}{l}\text { I can successfully call on people regardless of race/ethnicity to support } \\
\text { my work as an administrator. } \\
\text { I can utilize community resources to enhance my effectiveness in my } \\
\text { school/district. } \\
\text { I have professional mentors who effectively offer advice and provide } \\
\text { support. }\end{array}$ \\
\hline
\end{tabular}


The two open ended questions allowed each respondent to provide a more specific, detailed narrative response. These items collected data about the respondents' perception of how his or her Blackness affected their role as an administrator. More specifically, the respondent was asked to share his or her perception as it related to: (a) how his or her Blackness influenced their work as an administrator and (b) how his or her Blackness influenced how others viewed their work as an administrator. These questions were included to illicit detailed, individualized responses from each administrator regarding his or her administrative experiences as it related to his or her Blackness. The survey is presented for reference in Appendix C.

\section{Interview Protocol}

I conducted semi-structured interviews meaning there was a specific topic with questions prepared prior to the interview with plans to ask follow-up questions (Rubin \& Rubin, 2012). According to Rubin and Rubin (2012) interviews are common in qualitative studies conducted in the field of education and those interviews focus on the research question. Rubin and Rubin also suggest the purpose of qualitative interviews is to focus more deeply on a less broad scope of topics than a typical conversation.

Rubin and Rubin (2012) suggest an interview consist of main, probing and follow-up questions. Based on that suggestion, each interview consisted of six common questions posed to each interviewee and three or four clarifying questions based on responses to the openended survey questions specific to each interviewee. Each interview was conducted via Zoom, a video conferencing platform, and lasted approximately 30 minutes.

Rubin and Rubin (2012) describe cultural interviews as interviews purposed to understand the norms, rules and values that are central to one's behavior, morals and heritage. In addition, cultural interviews are investigative in nature and allow the researcher to identify terms, 
behavior or that reflect the typicality and ethics of the participants. Miles et al. (2020) posit that contrary to quantitative studies qualitative studies focus in depth on small samples in their context.

Based on distribution of participant responses on the Likert scale items on the survey, I developed four interview questions to each be asked of both interview participants. Next, I reviewed the individual interviewee's responses to the open ended-questions create clarifying, probing questions for the semi-structured interviews. An additional three questions were included in one interview and an additional four questions were included in the other interview. The interview protocols are in Appendix D.

\section{Data Analysis}

\section{Analysis of Survey Data}

Quantitative data was analyzed using Qualtrics and Statistical Package for the Social Sciences (SPSS). Trends and patterns in data related to the intersection of education, race, racism, and the six forms of cultural capital were used to create the interview questions for the second, qualitative, phase of the study. In addition, data from the quantitative phase of the study was reviewed to identify responses and topics that required elaboration or explanation during the interviews conducted during the second phase of the study.

\section{Likert Scale Data}

Once the data was collected, I began the analysis process. First, I analyzed the distribution of responses across the Likert scale options for each item. Next, I identified the modal response for each item to identify the response that occurred most frequently. 


\section{Open Ended Questions}

The data collected via the open ended survey questions was analyzed through the lens of Yosso's (2005) six forms of cultural capital: (a) aspirational, (b) familial, (c) linguistic, (d) navigational, (e) social, and (f) resistant. First, each response was reviewed and categorized as being related to one of the six forms of cultural capital.

\section{Analysis of Interview Data}

To begin the analysis of data, I assigned codes to small sections of each interview transcript. A code is a word or short phrase that captures the essence of a portion of languagebased data such as that found in an interview (Miles et al., 2020; Saldana, 2016). There are many things to consider when choosing coding methods for the analysis of qualitative data. According to Saldana (2016), analyzing qualitative data is not linear, but cyclical often requiring several cycles of coding. I used attribute coding, in vivo coding, and focused coding in my analysis.

Each qualitative study is distinct requiring a unique coding approach (Saldana, 2016). Saldana (2016) suggests researchers (a) consider which coding technique will yield the types of answers required by the research questions, (b) the form of data being analyzed, and (c) the compatibility of coding methods if more than one method is chosen.

Before selecting coding methods, I considered the importance of honoring each interviewee's voice. In addition, the attribute or descriptive data about each interviewee played an important role in providing context for analysis and interpretation. After considering the various forms of first cycle coding, I utilized attribute coding and in vivo coding in the first cycle. To reorganize and further analyze the data, I completed a second cycle of coding. The second cycle of coding used was focused coding. Each method of coding is described in greater detail below. 
Attribute coding is applicable to all qualitative studies and provides important participant information which provides context for data analysis and explanation (Miles et al., 2020; Saldana, 2016). Attribute coding was appropriate for the analysis of the qualitative data because the interviewee's attributes are significant in this study. In fact, only participants who met the inclusion criteria: (a) Black (b) administrator, and (c) currently or formerly serving in the PK-12 public school setting in the United States were selected to participate in the study.

Like attribute coding, in vivo coding is applicable to all qualitative studies and is a simplistic form of analysis for novice researchers. In vivo coding is also a form of analysis that is effective in paying tribute to and appreciating the voice of each participant (Miles et al., 2020; Saldana, 2016). Most important, each in vivo code is produced by the words of the participant, not the researcher.

In like manner to attribute and in vivo coding, focused coding is appropriate for most qualitative studies. The purpose of focused coding is to develop the main categories or themes for data. The important codes and those that are used most often throughout the data are used to develop categories or themes for qualitative data (Auerbach \& Silverstein, 2003; Saldana, 2016).

\section{First Cycle Coding}

First, I used attribute coding to begin the data analysis. I coded the participants' district locale and size, grade level, position, experience and gender. In this study, attribute coding is significant because the attributes or characteristics of each participant play a significant role in answering the research questions.

Next, I used in vivo coding to further analyze the data found in the interviews. I began the process by reading each interview several times to get a deeper understanding of each participant's unique point of view and responses. After I became familiar with the content of 
each interview transcript, I began assigning codes to small segments of text. In vivo coding produced 113 codes.

After reviewing the 113 in vivo codes, I created 39 clusters of similar codes. Each code cluster contained between two and nine in vivo codes. The 39 clusters were collapsed into the 10 categories based up their similarities. After another examination of the clusters, I created 10 categories: (a) race, (b) personality, (c) challenges, (d) skill, (e) drive, (f) class and values, (g) the work (h) spaces and marginalization, (i) perseverance, and (k) experience as depicted below in Figure 1.
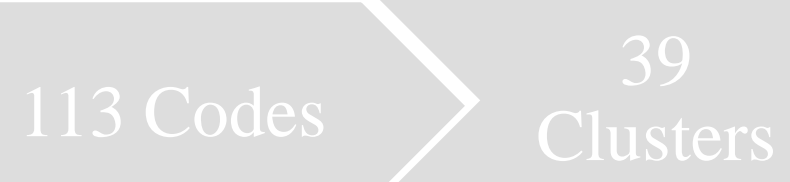

Figure 1. Diagram: First Cycle Coding

\section{Second Cycle Coding}

To begin the second cycle of coding, I reviewed the ten categories created during the first cycle to find similarities between the categories. By using focused coding, the similarities in the 10 categories were first used to create four themes. The four themes were: (a) describing self: 
identifying the individual, (b) exploring the advantages of being Black: drive and perseverance, (b) navigating administrative roles: service and competencies, and (d) encountering racism.

Then, each of the four themes were assigned two or three subthemes. Describing self: identifying the individual incorporated three subthemes: (a) considering race, (b) describing personality, and (c) stating class and values. Exploring the advantages of being black: drive and perseverance included two subthemes: (a) creating drive, and (b) inspiring perseverance. Navigating administrative roles: service and competencies encompassed three subthemes: (a) sharing experiences, (b) recognizing skills, and (c) doing the work. Finally, encountering racism constituted two subthemes: (a) enduring challenges, and (b) conquering spaces and marginalization as show in Figure 2 below.

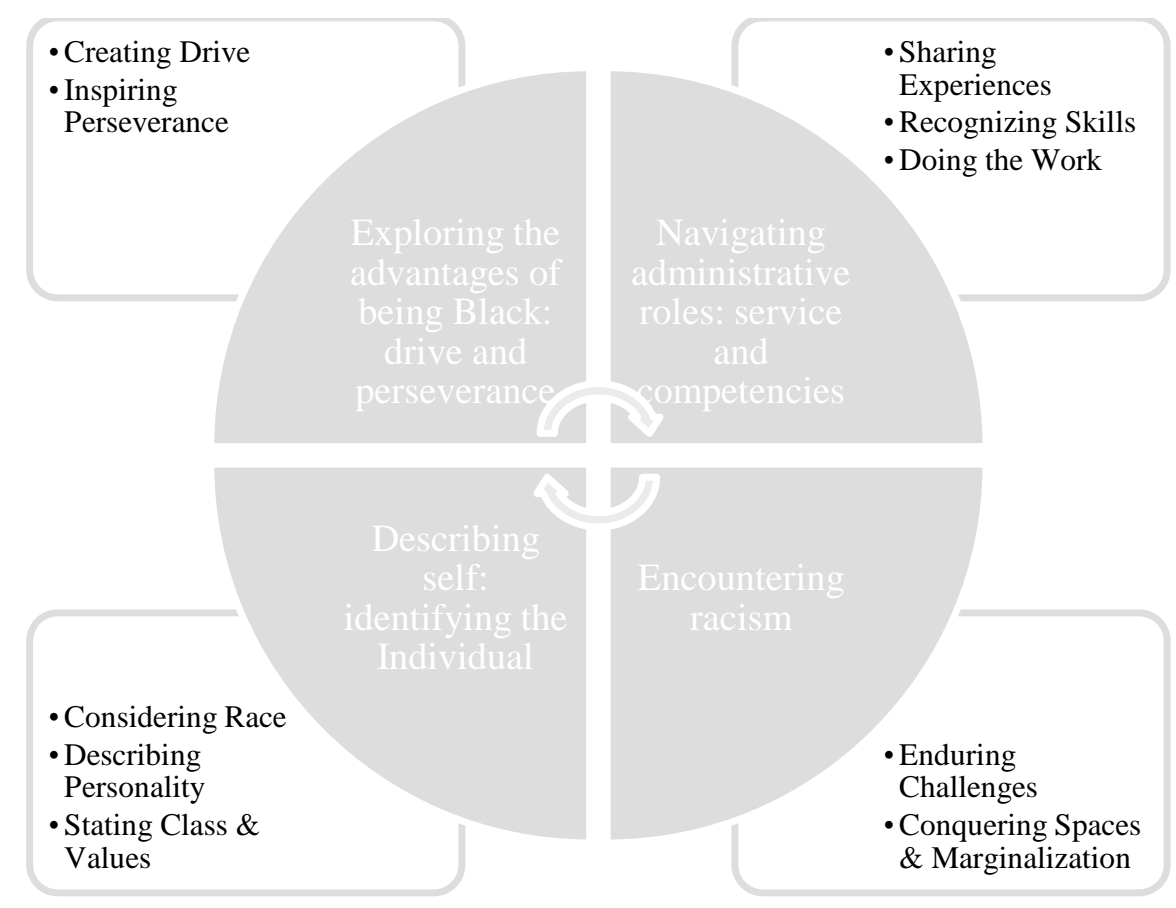

Figure 2. Diagram: Second Cycle Themes and Subthemes 


\section{Mixed Methodology Data Analysis}

I conducted data analysis in two phases. I analyzed and interpreted the quantitative data and the qualitative data separately. The data collected during the interviews in the second phase of the study were used to explain and or elaborate upon the phenomena identified during the quantitative phase of the study. The analysis and interpretation of all data throughout both phases of the study were framed by the theories of CCW and CRT. These theories were used as lenses to frame the research questions, the survey items, and the interview questions. In addition, the theories of CCW and CRT were used to frame the findings and implications of the study as it relates to the experiences of the participants in the study.

\section{Researcher Positionality}

I am a Black female administrator. I have encountered both positive experiences and barriers in attempting to create equitable learning experiences through cultural responsiveness while navigating my leadership role within the PK-12 public school setting. In my first administrative role, I was one of two Black administrators in a small, suburban K-12 district serving approximately 4,600 students. Approximately 1,800 of the students identified as two or more races, Black, Latinx, or Indigenous. Ninety-five percent of the teachers identified as White and less than $1 \%$ of the teachers identified as Black. Currently, I am a district administrator in a small urban K-8 district serving approximately 1,500 students. Approximately 3,100 of the students identify as two or more races, Black, Latinx, or indigenous. There are five Black administrators in the district, $81 \%$ percent of the teachers identify as White and $11 \%$ of the teachers identify as Black.

I have had positive experiences including acting as a role model for BIaLS. I am also a change agent as part of my role which is to build capacity as it related to teachers' cultural 
responsiveness. Unfortunately, I have also had some negative experiences including racism, stereotypical behavior, and a lack of cultural competency. For example, I have been accused of favoring or being more lenient as it related to the discipline of Black students. Staff members reported fabricated stories about me to cause district administrators to question my competence as a building administrator. In addition, I have experienced White administrators asking me to reach out to families when the behavior of a Black student was inappropriate even if I was not involved in the disciplinary action. On several occasions, White teachers have referred Black students to me for behavior they considered to be inappropriate and or unacceptable despite the fact the behavior in question was acceptable as it relates to Black culture.

\section{Resources and Skills of the Researcher to Conduct Mixed Methods Research}

I am a doctoral student working toward a doctoral degree in special education. I earned a dual Bachelor of Science degree in elementary and special education before earning professional educator licensure. In addition, prior to my doctoral work, I earned a Master of Arts degree in leadership in educational administration.

I have three years' experience as a general education in an elementary public school setting serving BIaLS and of low SES and eight years' experience as a special education teacher in the PK-12 public school setting serving SOC and of low SES. In addition, I have experience in building and district level administration in public school settings. Currently, I serve as a district level administrator in a public elementary school district where approximately $65 \%$ of the students are of low SES and 70\% of the students are students are SOC.

As part of my doctoral work, I completed an examination of mixed methods research designs. Initially, I identified and studied mixed methods research designs typically used in the social and behavioral sciences. More specifically, I identified and studied the burgeoning use of 
mixed methods research designs in special education. Finally, I explored and studied how to assess the quality and rigor of mixed methods research designs.

\section{Ethical Concerns}

Prior to the study, an application detailing my study was submitted to the institutional review board at Illinois State University. At the start of the study, potential participants were informed of the purpose of the study and how the data collected would be used. All participants were of the age of majority and provided informed consent prior to participating in the study. The quantitative data collected via survey was collected anonymously. Further, all participants interviewed as part of the second phase of the study are identified in the study via pseudonym and no identifying information was disclosed as part of the study to protect their anonymity. Finally, all data collected during the study will be securely stored for five years. 


\section{CHAPTER IV: RESULTS}

Chapter four represents the findings from a transformative explanatory sequential mixed methods design study conducted to answer the following questions:

RQ1: How does cultural capital affect the experiences of Black administrators in the PK-12 public school setting in the United States?

RQ2: What are the positive experiences of Black administrators in the PK-12 public school setting in the United States?

RQ3: Which barriers are encountered by Black administrators in the PK-12 public school setting in the United States?

RQ4: To what extent do positive experiences help Black administrators in the PK-12 public school setting in the United States as they attempt to create equity through culturally responsive school policies and practices?

RQ5: To what extent do barriers hinder Black administrators in the PK-12 public school setting in the United States as they attempt to create equity for BIaLS?

\section{The Affect of Community Cultural Wealth on the Experiences of Black Administrators}

The first phase of this study was quantitative. I collected data with a Likert scale survey. Survey items were created to reflect Yosso's (2005) six forms of cultural capital in her CCW model: (a) aspirational, (b) familial, (c) linguistic, (d) navigational, (e) resistant, and (f) social. I used data from survey responses to answer RQI: How does cultural capital affect the experiences of Black administrators in the PK-12 public school setting in the United States? Table 4 depicts the distribution of responses to each of the 18 Likert scale questions. 
Table 4

Percentage of Responses Distributed across Response Options

\begin{tabular}{|c|c|c|c|c|c|c|c|}
\hline Survey Item and Form of Capital & Very true & True & $\begin{array}{c}\text { Somewhat } \\
\text { True }\end{array}$ & Neutral & $\begin{array}{c}\text { Somewhat } \\
\text { Untrue }\end{array}$ & Untrue & $\begin{array}{c}\text { Very } \\
\text { Untrue }\end{array}$ \\
\hline $\begin{array}{l}\text { I have succeeded as an administrator } \\
\text { despite barriers to my } \\
\text { success. (aspirational) }\end{array}$ & $19 \%$ & $45 \%$ & $26 \%$ & $5 \%$ & $2 \%$ & $2 \%$ & $0 \%$ \\
\hline $\begin{array}{l}\text { I am confident in my ability to work } \\
\text { through conflicts in my school } \\
\text { district. (aspirational) }\end{array}$ & $17 \%$ & $60 \%$ & $10 \%$ & $10 \%$ & $2 \%$ & $2 \%$ & $0 \%$ \\
\hline $\begin{array}{l}\text { I do not allow racism or stereotypes to } \\
\text { negatively affect my } \\
\text { aspirations. (aspirational) }\end{array}$ & $55 \%$ & $24 \%$ & $17 \%$ & $5 \%$ & $0 \%$ & $0 \%$ & $0 \%$ \\
\hline $\begin{array}{l}\text { I can successfully call on people } \\
\text { regardless of race/ethnicity to } \\
\text { support my work as an } \\
\text { administrator. (social) }\end{array}$ & $40 \%$ & $36 \%$ & $14 \%$ & $0 \%$ & $7 \%$ & $1 \%$ & $2 \%$ \\
\hline $\begin{array}{l}\text { I can utilize community resources to } \\
\text { enhance my effectiveness in my } \\
\text { school/district. (social) }\end{array}$ & $19 \%$ & $43 \%$ & $24 \%$ & $2 \%$ & $10 \%$ & $0 \%$ & $2 \%$ \\
\hline $\begin{array}{l}\text { I have professional mentors who } \\
\text { effectively offer advice and provide } \\
\text { support. (social) }\end{array}$ & $36 \%$ & $26 \%$ & $26 \%$ & $2 \%$ & $5 \%$ & $0 \%$ & $5 \%$ \\
\hline $\begin{array}{l}\text { Support from my family has facilitated } \\
\text { my success as an administrator. } \\
\text { (family) }\end{array}$ & $57 \%$ & $29 \%$ & $10 \%$ & $0 \%$ & $2 \%$ & $2 \%$ & $0 \%$ \\
\hline
\end{tabular}

(Table 4 continues) 


\begin{tabular}{|c|c|c|c|c|c|c|c|}
\hline Survey Item and Form of Capital & Very true & True & $\begin{array}{l}\text { Somewhat } \\
\text { True }\end{array}$ & Neutral & $\begin{array}{l}\text { Somewhat } \\
\text { Untrue }\end{array}$ & Untrue & $\begin{array}{l}\text { Very } \\
\text { Untrue }\end{array}$ \\
\hline $\begin{array}{l}\text { My family members acknowledge and } \\
\text { celebrate my professional } \\
\text { accomplishments. (family) }\end{array}$ & $74 \%$ & $17 \%$ & $7 \%$ & $0 \%$ & $0 \%$ & $2 \%$ & $0 \%$ \\
\hline $\begin{array}{l}\text { My family members are empathetic } \\
\text { when my professional } \\
\text { responsibilities extend beyond the } \\
\text { school day. (family) }\end{array}$ & $40 \%$ & $40 \%$ & $12 \%$ & $5 \%$ & $0 \%$ & $2 \%$ & $0 \%$ \\
\hline $\begin{array}{l}\text { I believe that one of my roles is to } \\
\text { address racial/ethnic in justices in } \\
\text { my school/district. (resistant) }\end{array}$ & $36 \%$ & $43 \%$ & $7 \%$ & $7 \%$ & $5 \%$ & $2 \%$ & $0 \%$ \\
\hline $\begin{array}{l}\text { I believe part of my role is to make a } \\
\text { difference in my school community } \\
\text { and broader society. (resistant) }\end{array}$ & $67 \%$ & $26 \%$ & $7 \%$ & $0 \%$ & $0 \%$ & $0 \%$ & $0 \%$ \\
\hline $\begin{array}{l}\text { I believe education should serve to } \\
\text { address the problem of racism in our } \\
\text { society. (resistant) }\end{array}$ & 38\% & $36 \%$ & $17 \%$ & $5 \%$ & $0 \%$ & $5 \%$ & $0 \%$ \\
\hline $\begin{array}{l}\text { My dialect is honored in my } \\
\text { professional community. (linguistic) }\end{array}$ & $14 \%$ & $19 \%$ & $21 \%$ & $21 \%$ & $10 \%$ & $5 \%$ & $7 \%$ \\
\hline $\begin{array}{l}\text { Code switching is not necessary for my } \\
\text { communication skills to be } \\
\text { validated. (linguistic) }\end{array}$ & $14 \%$ & $17 \%$ & $17 \%$ & $17 \%$ & $14 \%$ & $7 \%$ & $12 \%$ \\
\hline $\begin{array}{l}\text { My linguistic roots connect me with } \\
\text { students, families and community } \\
\text { members. (linguistic) }\end{array}$ & $31 \%$ & $43 \%$ & $14 \%$ & $7 \%$ & $0 \%$ & $2 \%$ & $0 \%$ \\
\hline
\end{tabular}




\begin{tabular}{|c|c|c|c|c|c|c|c|}
\hline Survey Item and Form of Capital & Very true & True & $\begin{array}{c}\text { Somewhat } \\
\text { True }\end{array}$ & Neutral & $\begin{array}{c}\text { Somewhat } \\
\text { Untrue }\end{array}$ & Untrue & $\begin{array}{c}\text { Very } \\
\text { Untrue }\end{array}$ \\
\hline $\begin{array}{l}\text { I know how to find resources to help } \\
\text { me succeed. (navigational) }\end{array}$ & $53 \%$ & $43 \%$ & $21 \%$ & $2 \%$ & $0 \%$ & $0 \%$ & $0 \%$ \\
\hline $\begin{array}{l}\text { I am confident in my ability to network } \\
\text { within and/or outside my school } \\
\text { district (navigational) }\end{array}$ & $29 \%$ & $40 \%$ & $26 \%$ & $5 \%$ & $0 \%$ & $0 \%$ & $0 \%$ \\
\hline $\begin{array}{l}\text { I am provided with adequate resources } \\
\text { to help my staff and students } \\
\text { succeed. (navigational) }\end{array}$ & $12 \%$ & $29 \%$ & $38 \%$ & $10 \%$ & $7 \%$ & $0 \%$ & $2 \%$ \\
\hline
\end{tabular}


The survey included 18 items reflecting the six forms of cultural capital. Each form of capital had three corresponding questions meant to collect data from each participant related to that specific form of capital. Two of the three items related to aspirational capital were rated as true by the greatest percentage of respondents and true was the mode for those items, while one item was rated as very true by the greatest percentage of respondents with very true being the mode for that item.

Two of the three items related to familial capital were rated as very true by the greatest percentage of respondents with very true being the mode for those two items, while one item was rated as either true or very true by an equal percentage of respondents with true and very true being the modes for that item.

One item related to linguistic capital was rated as true by the greatest percentage of respondents with true being the mode for that item. A second item related to linguistic capital was rated as neutral or somewhat untrue by an equal percentage of respondents with neutral or somewhat true being the modes for that item. The third item related to linguistic capital was rated true, neutral or somewhat untrue by an equal percentage of respondents with true, neutral or somewhat true being the modes for that item.

One item related to navigational capital was rated as very true by the greatest percentage of respondents with very true being the mode for that item. A second item related to navigational capital was rated as true by the greatest percentage of respondents with true being the mode for that item. A third item related to navigational capital was rated as somewhat true by the greatest percentage of respondents with somewhat true being the mode for that item.

Two items related to resistant capital were rated as very true by the greatest percentage of respondents with very true being the mode for those items. A third item related to resistant 
capital was rated as true by the greatest percentage of respondents with true being the mode for that item.

Two items related to social capital were rated as very true by the greatest percentage of respondents with very true being the mode for those items. A third item related to social capital was rated as true by the greatest percentage of respondents with true being the mode for that item.

\section{Open Ended Questions}

In addition to the demographic and Likert scale items, the survey included two open ended questions. The first open ended question was how does or did my Blackness influence my work as an administrator? Thirty-nine $(n=39)$ participants answered the first open ended question.

\section{How Blackness Influenced Administrators' Work}

In the following narrative, I discuss the responses to the first open-ended question. I present the responses as they relate to Yosso's (2005) six forms of cultural capital. The analysis of the responses to each open-ended question yielded various themes.

Aspirational. Twelve of the responses to the open-ended questions related to aspirational capital. More specifically, the responses were related to fostering aspirational capital in BIaLS. I identified two themes in those responses. The first theme was acting as a role model, illustrated by responses such as, "One of the reasons I became an administrator is so that my Black students could see people who look like them in leadership roles. I serve as a role model and voice for all of my students." Another participant responded,

I serve as a role model for Black students to recognize that success within the educational

system is possible. I also serve as a role model for non-Black students to see a Black male 
as a positive and productive member of the community. Many of which may not know a Black male outside of the school setting.

The second theme that emerged was advocacy as illuminated by responses such as, "Parents, students, and the broader community need representatives who advocate for and demonstrate to them what it means to use education as a means to reach success." Another participant responded by saying,

Parents and students feel a sense of relief and comfort when they see me. They feel that I am relatable, have compassion, will be reasonable and fair. I also let the students and parents know I believe in them and I'm here to help.

Familial. I did not identify any responses to the first open-ended question that related to familial capital. Many participants' responses were related to how they form relationships with students' families. But, none of the responses were related to how participants' familial capital was leveraged as part of their administrative roles.

Linguistic. Analysis of two responses related to linguistic capital were related to effective communication with all stakeholders. One participant indicated, "It helps me communicate more effectively with the majority of my students and their parents. It also helps me communicate and connect with some of my staff, particularly the paraprofessionals." Another participant responded by saying, "My Blackness dictates how I communicate with students, families and some staff members."

Navigational. Many participants' responses reflected how racism effected their ability to utilize their navigational capital. Analysis of eight responses related to navigational capital produced two themes. The first theme was isolation as one participant stated, "Prior to this school I was a token on the administrative cabinet, and I felt undervalued." Another participant 
recounted, "It was isolating when collaborating with a nearly all White upper management and district office staff." Yet another participant responded by saying, "When a teacher or parent have a problem, they bypass me and goes straight to the (White) principal. I do sometimes feel inadequate to be in my position during those times." The second theme was individualism as evidenced by one participant who reported, "I say things a certain way." Another participant noted, "I do things a certain way. Sometimes my way is more effective and sometimes not as much."

Resistant. Two themes emerged when analyzing the nine responses related to the resistant form of cultural capital. The first theme was resilience as one participant stated, "I could have any number of jobs outside of public-school education but have chosen to remain." A second participant noted, "My Blackness has had no influence or impact on my work as administrator. Professionalism, integrity, consistency, and fairness have had the greatest influence."

Advocacy was the second theme that emerged within the responses related to the resistant form of cultural capital. One participant stated, "My Blackness greatly influences what I do as a leader. This is especially true when I advocated for a less punitive discipline systems." A second participant noted,

My Blackness has allowed me to connect better with my students' families when different situations arise. My ability to understand and empathize and/or share a common experience helps me in problem-solving with families and share possible solutions with my staff.

Social. During analysis of the 22 responses the theme that emerged was connectedness. Most participants' responses included a sense of connection. One responded reported, "I connect 
with students, peers and colleagues like a Black man because that's who I am. I see things a certain way." Another participant stated, "I am able to connect to Brown and Black students on a different level."

\section{How Blackness Influenced How Others Viewed Administrators' Work}

As stated previously, in addition to the demographic items and the Likert scale items, the survey contained two open ended questions. The second open ended question was how does or did my Blackness influence how others view my work as an administrator? Thirty-six $(\mathrm{n}=36)$ participants answered the second open ended question. In the following narrative, I discuss the responses to the second open-ended question. I present the responses as they relate to Yosso's (2005) six forms of cultural capital. The analysis of the responses to each open-ended question yielded various themes.

Aspirational. When the analysis of the four participant responses related to the aspirational form of capital was complete, the theme of possessing a strong work ethic emerged. One participant responded by saying, "My commitment and work ethics influence how others view my work as an administrator." Another participant noted, "I think others respect my opinion not based upon my color but in my practices of being considerate and compassionate about others and the work. I strive to be a model of helping everyone I can and/or providing them with resources if I can't help them.”

Familial. I did not identify any responses to the second open-ended question that related to familial capital. Many participants' responses were related to how they form relationships with students' families. But, none of the responses were related to how participants' familial capital was leveraged as part of their administrative roles. 
Linguistic. None of the responses to the second open ended question were related to the linguistic form of cultural capital. This is noteworthy. The responses to the Likert scale style questions related to this form of capital were the least positive.

Navigational. Similar to the responses to the first open ended question, many participants' responses reflected how racism effected their ability to utilize their navigational capital. Regrettably, analysis of the eight responses related to the navigational form of cultural capital revealed a theme of feeling undervalued. One participant lamented, "[Others] want to use me as a disciplinarian as opposed to other responsibilities of an administrator." A second participant commented,

Well, I honestly believe that a Black administrator has to prove his or her worth/value. Subconsciously, others want to know if you're competent, whereas, non-Black administrators are given the benefit of the doubt they are "worth their salt." I'm not sure if it is that way for all Black administrators, whether it is more of the experience of Black males, or whether it is simply my own personal experience. On the flip side, I notice that I do have immediate passport with Black employees. In other words, they give the benefit of the doubt without a "proving time."

Resistant. Two themes, one being challenge, emerged during the analysis of the twelve responses related to the resistant form of cultural capital. A participant noted, "My Blackness is unapologetic. It is who I am. It what I do. That being said, sometimes your Blackness causes others, Black and White to prejudge your intelligence. You have to prove yourself and what you know." A second participant stated,

Most people know that I am an advocate for all children and understand that expect all cultures to be celebrated. Some respect that I don't shy away from the 
hard conversations related to race and student performance. Some feel that I have a personal agenda and will challenge my push for equity.

A third participant had a similar response,

As a brown person, people of other races tend to challenge me. They are aggressive and then blame me for it. They also do not think that I should be as intelligent as I am. I use the microaggressions as an impetus to push me forward despite how others act. I use those microaggressions as an incentive to show up every day and perform well for my community, African Americans.

The second them that emerged was a sense of being "used". One participant said, "I think my district supports me because I look the part: A person of color. However, my background is middle class from outside of the USA. I approach my work differently than a person who grow up in the racism of the USA.” A second participant noted,

A lot of White people feel like I'm the voice for the entire race of Black people. So, I'm invited into the room when conversations arise about the African American population. They come to me when they need to speak with a Black parent or when they are struggling with the behaviors of a Black child. I have encountered a few people over the course of my career who wanted to challenge my intellect, and I'm positive it's because of my skin color and the stereotypes and racist views they hold.

Social. The seven responses related to the social form of cultural capital were analyzed. Interestingly, two opposing themes were revealed. The first was the theme of respect. On the one hand, a participant reported, "I have been accepted as a positive and strong Black female leader in my school and school district." A second participant noted, "They respect my points of views and perspective more openly." On the other hand, the theme of stereotypical perceptions 
emerged. A participant reported, "I think it has caused me to be pigeonholed at times as one who can only work with "Black kids" or being a straightforward leader is often characterized as 'angry'.” Another participant commented,

I'm very respected by families and staff (especially Black women). I've had situations where I've been called harsh or ghetto because of my Blackness. I'm also judged at times for how I wear my hair. My middle school students were very excited when I got box braids. They felt like their school leader looks like them. Because of that I wear my weave less than I used to.

\section{Interview Data}

Through responses gathered during the two interviews, participants shared experiences that have taken place during their tenure as administrators. From the data gathered from the interviews, I was able to analyze and explore data to answer research questions 2, 3, 4 and 5. Several themes emerged during the second phase of the study: (a) describing self: identifying the individual, (b) exploring advantages of being Black: drive and perseverance, (c) navigating administrative roles: service and competencies, and (d) encountering racism. While some experiences were positive, others were not.

At the time of the interview Stephanie Donovan, a Black female administrator, had served as an administrator for 13 years. She was an assistant principal for seven years. She then became a building principal and has held that post for six years in a small suburban district in the midwestern United States. At the time of the interview Madeline Samuels, also a Black female administrator, had been and educator for 25 years. These years were spent in another country, the Eastern United States, and the Pacific Northwestern United States. Having served as an assistant principal for seven years outside of the United States and in the Pacific Northwestern United 
States., she was currently beginning her first year as a building principal in a school for advanced learners in a large urban school district in the Pacific Northwestern United States.

\section{Positive Experiences of and Barriers Encountered by Black Administrators}

\section{Describing Self: Identifying the Individual}

The theme of describing self: identifying the individual encompasses the qualities of each participant. Throughout the interviews, the participants shared personal details about their individual personalities and their personal values. They also reported how race affected them both personally and professionally.

As Madeline described positive experiences during her tenure as an administrator, she reported that "people judge me by my skills rather than a person of color." She expressed that part of her positive experience may be attributed to the fact that she is not American by saying, "I think there are a lot of things I approach and look at differently." She continued, "I'm saying there is a different perspective in the way we look at the world."

Madeline also noted her background and experiences were dissimilar to the experiences of the BIaLS to which she tried to provide culturally responsive teaching policies and practices. She did not grow up in poverty and was fortunate enough to go to college and have a successful career in public education. She described herself by saying, "I have very middle-class values." Noted in an analytic memo, at this point in the interview I got the sense that Madeline wondered if the fact that her upbringing was different from that of her students affected how she navigated her administrative role while working to support BIaLS.

Madeline referred to her own educational experience often during the interview she said that "most of the time I was the only person of color in my school." I got the impression that her personal experiences served as a source of reference as she navigated her administrative tenure. 
Madeline, an administrator in the Pacific Northwestern United States at the time of the interview, said, "in New York I think were more administrators of color." She went on to remark, "Sometimes I feel like an outlier" when asked about her professional history. As noted in an analytic memo, it struck me as peculiar that the number of Black administrators was mentioned when referencing her extensive career in education. To me, this indicated that the small number of administrators in that part of the country was very much on Madeline's mind. While Madeline reported a positive experience of being judged by her work rather than the color of her skin, one of the barriers encountered by administrators that are Black is that they are so few in numbers. Stephanie commented that she could "count on one hand the number of people of color who'd been administrators" during her tenure as an administrator.

Stephanie also had positive experiences related to the theme of describing self: identifying the individual. Stephanie reported one of the positive experiences of her administrative tenure was the fact that she was able to leverage her linguistic capital by saying, "I haven't had to code switch." She went on to explain that throughout her career she was able to “maintain a pretty consistent linguistic pattern." Stephanie's focus on linguistic capital contrasted with Phase One findings. In the survey, linguistic capital was the one form of cultural capital to which administrators responses were neutral.

While Stephanie herself had positive experiences related to linguistic capital. She also spoke about having to coach White educators before meeting with the families of BIaLS to share with them that you "don't assume you are going to have to have a confrontational parent just because they are a minority parent." It had been Stephanie's experience that White educators could be insensitive and ask inappropriate questions based on stereotypical beliefs which led her to remind them to choose their words carefully when meeting with families of color "because we 
don't want to pose those kinds of questions to families in general. But, especially not to our minority families."

Also, surprising, was Madeline's response when I asked her to tell me about the barriers she'd encountered during her administrative tenure. She said, "my biggest barrier in my entire time as an administrator is when I worked for...I had a...I served for a principal of color.” Frankly, I did not anticipate that one Black administrator would be described as a barrier by another. This was unexpected. According to Madeline, she was told that since she was from another country, of African descent and had a different perspective most families of BIaLS "didn't get the response that they were expecting" because they were accustomed to Americans occupying administrative roles.

\section{Exploring the Advantages of Being Black: Drive and Perseverance}

The theme exploring the advantages of being Black explores how each participant used bias and racism as a catalyst. Throughout the interviews, the participants shared how navigating barriers created a drive within to succeed. Each administrator also shared how they were able to endure and overcome obstacles despite numerous barriers.

When asked about how her Blackness influences her work as an administrator Madeline responded by saying, "I just do my work. I trained to do this job. I love what I do." She did not believe the fact that she was Black had any bearing on her job performance. She presented herself as a servant leader. When asked to describe her professional history she described a previous administrative position by replying, "I served for five years."

\section{Navigating Administrative Roles: Service and Competencies}

The theme of navigating administrative roles: service and competencies is related to the competent servant leadership exhibited by the participants that were interviewed. Each 
participant was. Servant leader. Further, it was evident that each participant possessed the competencies necessary to serve as advocates and change agents.

Many of Stephanie's positive experiences were connected to the fact that during her first administrative role her supervisor was another Black woman. She spoke of relying on "shared experience" with that supervisor during decision making. She said working with another Black female was a "very good experience" because they had similar ideas about how to lead a predominantly White staff toward cultural responsiveness and "having a shared experience and background" made joint leadership less difficult. She went on to say, "there was that shared understanding." She and her supervisor also knew how to communicate and build relationships with families "so, that didn't have to be explained."

Unfortunately, both Madeline and Stephanie shared numerous barriers they have encountered while navigating administrative roles. Madeline said she and fellow administrators sometimes felt as if "you have this artificial seal that's there, this glass ceiling." Further, when speaking of her White colleagues she reported feeling like "they're looking to try to put you in your place. You have to continue."

Stephanie's shared relationships with BIaLS were less difficult to build "because we have a shared experience and background." When talking about handling discipline issues, Stephanie said, "I think I am able to understand and kind of walk it through" because students explaining why they did not meet behavior expectations "they don't have to try to, again, explain it to me." She went on to say, "They're okay with coming and telling me." Students felt comfortable with Stephanie because she said, "I know what they've been talking about."

In addition, Stephanie felt that being a woman of color afforded her positive experiences with students. She expressed that feeling during her interview by saying, "so, that I think, really 
helps me in my relationship with the students." Some BIaLS are disciplined at home and want to avoid that by talking to her. Stephanie says, "I understand that" as opposed to a White administrator being more likely to not understand the disciplinary actions taken by a family of color. She went on to say, "one thing I have found that my parents will trust me."

Stephanie reported that there were times when White teachers who had failed to build relationships with BIALs sometimes referred them to the office for disciplinary issues "that could be easily solved" if there was a better understanding and acceptance of BIaLS. She went on to explain that, as a Black administrator leading White teachers, she felt as if she had to spend a lot of time explaining how to best support BIaLS "because you really want them to understand versus just giving them a strategy of what to do." At this point in the interview, I sensed and understood her frustration, as indicated by an analytic memo.

\section{Encountering Racism}

The theme of encountering racism involves the barriers each participant encountered as a result of racism. Throughout their narratives, the participants shared unfortunate, hurtful experiences she had endured as a Black administrator. Evidence of racism was apparent in both administrator's experience.

Madeline talked about Black administrators remaining positive and their resilience and ability to "not allow people to tell us that we can't." When describing her own educational experience, she said, "I was more of an individual." When asked about how she overcame some of the barriers she encountered at the onset of her administrative tenure she said one thing that set her apart was that "I believe that everyone is an individual."

One of the barriers Stephanie spoke about was a sense of competition between herself and other Black administrators stating that part of her administrative tenure was a "bit of a 
challenge." She went on to say, "there's almost a feel" when she is in the presence of her White counterparts in the professional setting. She described being asked to present at a conference and getting a sense that her White peers did not believe she was competent. She said, "It's almost like they have to school me a little bit." She continued by saying, "It's like a prep session almost."

While Stephanie identified her linguistic capital as a positive experience, Madeline had a different experience. She described her interaction with some families by saying, "They don't connect my linguistic roots with who I present in person." She elaborated by saying, "I think the impact for some people is they don't think the speech fits with the package." Further, she explained that there were times that being from another country with a British accent "Made it hard for me to do my job."

When speaking of her Blackness and how it affected her administrative tenure, Madeline said, "I've encountered families who can't get past it." She recalled a family that did not agree with how she handled a situation as an assistant principal and called a meeting with the principal. The principal invited Madeline to the meeting. She said, "I could tell they were completely miffed when the principal invited me to the meeting. I have encountered that, and I think because I know what that looks like." Madeline also described feeling like some families perceived her Blackness as being negative. She remarked, "You can see it on the person's face when they're talking to you." She described encountering similar situations with families and enduring "that look from someone on their face."

As a person from a country other than the United States and of African descent, Madeline also shared her perspective was sometimes different than that of African Americans. She felt as if her Black administrator colleagues felt inadequate, "the area of town that I work in is off limits to them - that they can't break into it and yet here I am." She went on to say she felt that as Black 
Americans, "the trauma that they've [Black administrators] experienced through racism has given them the sense of inferiority."

I found Madeline's perception of her Black American colleagues intriguing. When she referred to her colleagues she said, "People feel there are spaces that they have been shut out of." She continued, "and in some ways, they shut themselves out of those spaces by not just boldly walking in." She reported that some Black administrator colleagues "feel that it has been a disadvantage to them being a person of color."

I asked Madeline how her Blackness influenced how others viewed her work as an administrator. Her response gave me pause perhaps because there may be some truth to it. Madeline said she thought that she may have been placed in an administrative role because "They want to make sure that they have Black administrators...I also think it plays a role in statistics."

Overcoming Barriers to Create Equity Through Cultural Responsiveness Describing Self: Identifying the Individual

Stephanie talked about barriers she encountered while attempting to create culturally responsive policies and practices. She described how she took responsibility for preparing White teachers to better communicate with and ask appropriate questions of families of color "Because we don't want to pose those kinds of questions to families in general. But, especially not to our minority families."

Describing the barriers she encountered when attempting to create equity, Stephanie reported the need to train and support "predominately White staff" in how to support BIaLS. I did not anticipate her saying she had experienced Black administrator colleagues "trying to make 
their own name and build their reputation." She seemed frustrated and shared with me that she felt the "competition supersedes kind of what we want to do for kids."

Madeline expressed that as someone from outside of the United States, she is more likely to adopt policies and practices that were inclusive in nature. Her perception was that Black administrators, Americans in general, were more likely to lean toward individualism. When asked about her leadership, Madeline said, "I think there are a lot of things that I approach and look at differently."

Again, Madeline's perspective as someone not from the United States was that "the United States is about testing. It's pervasive through American society." Her perception was that American schools focus too much on the individual and not enough on the group and that the focus on individualism was a barrier to creating equity.

Madeline said some of her Black administrator colleagues "have a problem breaking into communities where you have a high percentage of people who are not of color." That barrier must be cleared before a Black administrator can work toward creating equity. When describing her work environment Madeline stated, "I am the principal of the school that is probably the Whitest school in the entire district."

\section{Exploring the Advantages of Being Black: Drive and Perseverance}

Madeline spoke about the tenacity necessary to be effective as a Black administrator. She said, "You have to be able to thrive." When expressing her thoughts about creating culturally responsive policies and practices she said she would "help them navigate the system" to access the support they need. When asked if she believed some of the barriers she encountered were directly connected to her Blackness she said when she encountered those that did not accept her 
as a Black administrator attempting to create equity "I know when I'm in that situation. I have the ability to navigate it."

Toward the end of our interview, I asked Madeline if there was anything that she wanted to share that we had not talked about. She said that regardless of which barriers were present, as a Black administrator "You have to try to break through it." As an example of how she had overcome a barrier during her administrative tenure she talked about one instance in which she felt district level administrators did not act quickly enough in their decision making. She said she was thinking "I can't wait for your direction." In that moment I noted, I realized Madeline had a sense of urgency which likely increased her effectiveness in creating culturally responsive policies and practices.

\section{Navigating Administrative Roles: Competencies and Service}

During my interview with Madeline, I noted she seemed to have a fervor for creating equitable experiences. She talked about being passionate about providing not only students, but parents with the support they needed. She ended her statement by saying "I took that very seriously."

During her interview, Stephanie stated that the lack of time was a barrier. She reported finding herself spending a significant amount of time providing professional development related to culturally responsive practices to White teachers. Stephanie said she thought it was time well spent "because you really want them to understand versus just giving them a strategy of what to do." Like Madeline, Stephanie talked about the time required to support White staff. She remarked "it's just the timing factor and having to explain a lot."

Madeline had an affinity for BIaLS. She said, "I work with those students." She was able to empathize with them she remarked, "I feel and hear their pain, but it is not an experience that I 
personally have had." Madeline realized there was much work to be done before every student has an equitable learning experience. She said she planned to, and she wished more of her Black administrator colleagues would "pick up that baton and continue to do that work."

\section{Encountering Racism}

Despite any barriers Madeline may have encountered while attempting to create culturally responsive practices and policies, her perspective was that as Black administrators we should "not allow other people to tell us we can't." I noted in an analytic memo that I admired her sense of purpose and unwillingness to compromise. She described what drove her by saying, "I feel and hear their pain, but it is not an experience that I personally have had." I also noted in an analytic memo that her statement made me realize how Madeline managed to stay the course regardless of the circumstances.

Madeline described working for a supervisor that was not confident in her abilities based largely on the fact that she was Black and not from the United States. She said, "It made it hard for me to do my job." I empathized with her because race or ethnicity should not play a factor in the workplace.

Madeline also talked about feeling as if she was appointed to an administrative role because "It checks a box for them." She believed she may have been an administrator so the district she worked for could say "They didn't just hire an administrator; they hired a woman and a woman of color." She went on to describe a situation that occurred when she was an assistant principal and her principal invited her to a meeting with a family who did not agree with a disciplinary action she took. The family was upset that she had been invited to the meeting. Madeline said, "I don't even think my principal understood that dynamic. I did because I am a person of color." 
When speaking about how her Blackness affects the way others view her work, Madeline talked about some of the barriers Black administrators encounter while attempting to implement culturally responsive environments. She asserted that, despite those barriers, Black administrators must persevere. She said, "It may be uncomfortable or may be uncomfortable for the people around them." Sadly, Madeline stated "There are people who aren't going to like you." At this point as indicated in my analytic memo, I thought about the obstacles that have been overcome to create the tradition of educational excellence that exists among Black educators When asked to articulate some of the barriers she has encountered during her administrative tenure, Stephanie talked about how her White counterparts assumed she was incompetent. She went on to say "That's never something that's been explicitly stated...you're wondering, like, why? But you know why." Stephanie also talked about White educators struggling to provide culturally responsive learning environments. She said what is perceived to be inappropriate behavior by BIaLS is often not accurate "because that is what it always boils down to: "they were being disrespectful." She recalled what should have been minor behavior infractions being blown out of proportion and how it was "unnecessary to ramp up kids that we know are going to be challenging to begin with and based off of some very preconceived things." Stephanie went into detail describing an incident where she thought a Black female student and her family were subjected to stereotypical beliefs about how Black families styled their child's hair. The teachers made a statement that the family should spend less time braiding their daughter's hair and more time helping her with her homework. Stephanie said, "it bothered me when they made the statement." She was clearly upset by the recollection and stated "What does that have to do with anything? But, just that perception and to translate it to that thought? 
That was just outlandish to me! Why is that even a criterion or anything that you're paying attention to?"

Stephanie also talked about district administrators being a barrier in the process of trying to create culturally responsive policies and practices. She said it was not uncommon for district administrative to make promises that were not kept which caused her to share misinformation with families "because like I said higher ups or different entities have not followed through or just different things have happened." Parents would be upset with Stephanie. She reported feeling frustrated because "You know, this is beyond me. If it were in my power, it would be there." She lamented, "that's been a challenge for sure."

\section{Conclusions}

This chapter includes the results of the analysis, relates the analysis back to the research questions, and shows consistency of the analysis with CCW and CRT. Forty-two participants completed the survey in the first phase of this study. Two participants were interviewed during the second phase of this study. Interview questions were created to explore the positive experiences lived and barriers encountered by Black administrators as they worked to create equitable learning environments by implementing culturally responsive teaching practices and policies. All participants were Black administrators who were currently or who had served in the PK-12 public school setting in the United States during the last two decades.

During data analysis, there were two cycles of coding including three forms of coding: (a) attribute, (b) in vivo, and (c) focused. The two cycles of coding yielded 113 codes. The codes were collapsed into 39 clusters. The 39 clusters were further collapsed into 10 categories. Finally, the 10 categories were collapsed into four themes. The four themes were: (a) describing self: identifying the individual, (b) exploring the advantages of being Black: drive and 
perseverance, (b) navigating administrative roles: service and competencies, and (d)

encountering racism.

During the first phase of this study, the participants responded positively to questions about five of the six forms of cultural capital: (a) aspirational, (b) familial, (c) navigational, (d) resistant, and (e) social. Questions about the sixth form of cultural capital, linguistic capital, yielded more neutral, neither positive nor negative, responses. During the second phase of this study that included semi-structured interviews, participants shared the positive experiences of their administrative tenures and the barriers they've encountered while navigating their administrative roles. Chapter V includes the summary for the analysis and discussion on the four themes. 


\section{CHAPTER V: DISCUSSION}

The purpose of this qualitative study was to add to the body of research related to the experiences of Black administrators in PK-12 public school settings in the United States. In addition, this study adds to the limited extant research about how barriers may preclude Black administrators from creating equitable learning opportunities through cultural responsiveness. Chapter IV includes a discussion of the key findings. In this chapter, I include a discussion on the connections to this study and the theories of CRT and CCW, a discussion of the limitations of the study, and areas for future research. This chapter also contains a brief summary and seeks to answer five research questions that follow:

1. How does cultural capital affect the experiences of Black administrators in the PK-12 public school setting in the United States?

2. What are the positive experiences of Black administrators in the PK-12 public school setting in the United States?

3. Which barriers are encountered by Black administrators in the PK-12 public school setting in the United States?

4. To what extent do positive experiences help Black administrators in the PK-12 public school setting in the United States as they attempt to create equity through culturally responsive school policies and practices?

5. To what extent do barriers hinder Black administrators in the PK-12 public school setting in the United States as they attempt to create equity for BIaLS?

During the first phase of the study, participants responded to questions related to Yosso's (2005) six forms of cultural capital: (a) aspirational, (b) familial, (c) linguistic, (d) navigational, (e) resistant, and (f) social. Responses related to all but the linguistic form of cultural capital 
were positive. The responses related to the linguistic form of cultural capital were neutral, neither positive nor negative.

During the second phase of the study, four major themes emerged around the positive experiences and barriers encountered by Black administrators as they attempt to create equity for BIaLS. Those themes are (a) describing self: identifying the individual, (b) exploring the advantages of being Black: drive and perseverance, (c) navigating administrative roles: service and competencies, and (d) encountering racism. Some of the themes relate to the individual administrator. Other themes relate to the workplace. The themes related to the workplace encompass the culture of the educational setting and the various experiences of the administrators within that setting.

\section{Interpretation of The Findings}

\section{Quantitative Data}

The quantitative data gathered during this study was examined through the lens of Yosso's (2005) theory of CCW and the six forms of cultural capital. The impetus of Yosso's (2005) CCW is to shift from deficit thinking related to communities of color to a focus on how people of color can leverage cultural capital to navigate the educational environment. Further, Yosso's (2005) CCW has the objective of challenging the notion that the White middle class is the standard by which everyone is to be measured.

Burciaga and Kohli (2018) posit teachers of color bring insights related specifically to their own CCW. In addition, teachers of color intuitively use their cultural capital to create culturally responsive teaching environments. Rodela and Rodriguez-Mojica (2020) found that Latinx administrators drew from their community cultural wealth to implement culturally responsive practices and policies. Unfortunately, the Latinx administrators faced barriers similar 
to the participants in this study as they tried to move their buildings toward a more culturally responsive environment. The experiences of the Latinx administrators were not only similar to those of the Black administrators in this study but to the experience of Black administrators in previous studies (Bloom \& Erlandson, 2003; Brooks \& Jean-Marie, 2007; Henderson, 2015; Loder, 2005; Moore, 2013; Ononuju, 2016).

Throughout this study and previous studies Black administrators were able to use their cultural capital to overcome the barriers encountered while navigating their administrative roles (Bloom \& Erlandson, 2003; Brooks \& Jean-Marie, 2007; Moore, 2013). Fortunately, Black administrators in this and previous studies have used cultural capital to create positive experiences such as acting a role models or agents of change (Bloom \& Erlandson, 2003; Brooks \& Jean-Marie, 2007; Moore, 2013). Participants also used their aspirational capital to call for unbiased treatment of the parents of BIaLS.

Moreover, participants in this study reporting using familial capital to build relationships with their students. Yosso (2005) described familial capital as human resources students gain from their extended familial or community networks. The participants became part of their students' community network. The relationships formed with the students allowed the students to better identify with the participants and feel comfortable talking to the participants because there was a sense of connectedness. The importance of connections is evidenced by previous studies when Black male administrators reported a perception of paternalism (Henderson, 2015; Ononuju, 2016) and Black female administrators reported filling a surrogate parent role (Bloom \& Erlandson, 2003; Brooks \& Jean-Marie, 2007; Loder, 2005; Moore, 2013). This is significant because previous research indicates BIaLS often lack role models that look like and share the 
same experiences as them which contributes to the opportunity gap of BIaLS (Ingersoll \& May, 2011a).

Participants shared their experience of the need to be resilient while navigating their administrative roles. They also shared experiences of advocacy being seen as a significant part of their role as an administrator. Findings from a previous study showed administrators would share information about scholarship opportunities, tutoring, and other supports available to students most of whom were struggling academically (Brooks \& Jean-Marie, 2003). In addition, others utilized servant leadership to advocate for their students (Bloom \& Erlandson, 2003). Unfortunately, participants shared a perception of being used when sharing how they felt others viewed their work as a Black administrator. This finding is consistent with that of a previous study in which only Black administrators, not White administrators, were thought to be able to work with Black students (Moore, 2013). Similarly, feeling undervalued and not being appreciated for his or her competencies was mentioned by several participants in this study when considering how their work as an administrator was viewed by others. This finding is consistent with that of a previous study in which Black administrators were expected to maintain the status quo rather than act as change agents (Bloom \& Erlandson, 2003).

Participants in this study noted a sense of connectedness with their students due in part to the sharing of similar lived experiences. Some participants also shared they felt their work as a Black administrator was respected when viewed by others which is consistent with results from a previous study in which the participant reported working as hard as her staff as an administrator (Bloom \& Erlandson, 2003). On the contrary, others had the perception that stereotypes affected how others viewed their work as a Black administrator which is consistent with prior research wherein two Black male administrators reported experiencing the effects of the stereotypical 
belief about Black males' inability to communicate well with individuals of other ethnicities and a propensity to "take it easy" on Black students when addressing disciplinary issues (Henderson, 2015).

\section{Qualitative Data}

Each administrator's race, personality, class and values contributed significantly to how she navigated her role as an administrator and were subthemes of the theme of describing self: identifying the individual. The possession of intrinsic motivation or drive and the ability to persevere despite barriers in the workplace was noteworthy within the theme of exploring the advantages of being Black: drive and perseverance. Sharing experiences with other Black administrators, recognizing one's skills or ability to assume administrative abilities, and the ability to provide students with support through a lens of equity and empathy made it possible for these administrators to work toward creating equitable learning experiences for BIaLS while navigating their administrative roles was encompassed in the theme of navigating administrative roles: service and competencies. Further, encountering challenges, conquering spaces and marginalization, and doing the work were subthemes that emerged within the theme of encountering racism.

\section{Describing Self: Identifying the Individual}

Both participants interviewed identified race as a consequential factor that affected many facets of their administrative tenures. As suggested by Allen et al. (2013), administrators reported experiencing unconscious bias. The idea of advocacy and working to support BIaLS was a consistent theme throughout each interview. Both participants talked about encountering barriers but being able to overcome theme because of their strong work ethics and desire to create equitable learning opportunities. 
Participants spoke about navigating predominantly White staffs. This is supported by statistics released by the NCES and OCR that Black teachers comprise only $7 \%$ of U.S. public school teachers. The lack of Black administrators was also noted as supported by statistics reported by the NCES (2016) which indicate Black leaders represent approximately $10 \%$ of principals in the United States.

\section{Exploring Advantages of Being Black: Drive and Perseverance}

Throughout both interviews the participants recounted scenarios where guidance and support from superiors was lacking as evidenced by a previous study wherein Black administrators reported experiencing the "glass ceiling effect" (Moore, 2013). Each spoke about the passion they had for their work and being able to thrive as administrators despite the barriers encountered. Previous studies have substantiated and identified barriers such as: (a) fatigue and health issues, (b) the lack of professional development, (c) the lack of social capital, and (d) racism (Brubaker \& Coble, 2007; Echols, 2006; Henderson, 2015, Jean-Marie, 2013; Marshall, 2004; Wilkerson \& Wilson, 2017).

\section{Navigating Administrative Roles: Service and Competencies}

Each administrator also remarked about being resilient enough to navigate and overcome barriers to act as change agents and implement culturally responsive practices and policies in their buildings. In a previous study Bloom and Erlandson (2003) suggest administrators had the positive experiences of acting as change agents. This change is necessary as Castagno and Brayboy (2008) posit culturally responsive pedagogy requires teachers to have a certain level of cultural competence. Ladson-Billings (1994) recognized several attributes of culturally competent teachers: (a) acquiring a respect for cultural differences, (b) recognizing students from 
low SES are capable of being academically successful, and (c) becoming culturally sensitive by changing language or communication patterns.

\section{Encountering Racism}

Both participants reported encountering families who did not want to work with a Black administrator. This aligns with a previous study in which three principals from Chicago described community members making intentional efforts to undermine their authority as educational leaders (Loder, 2005). Another study found an administrator reported difficulty gaining parental involvement (Henderson, 2015).

Each participant that was interviewed remarked about others questioning their ability to be a competent leader. In 2015, Henderson found that a Black administrator was perceived to lack the skills required to be a good leader. In addition, each participant reported White teacher bias as a barrier which is consistent with the findings of Moore's (2013) study in which White teachers stated when talking about Black students "they should have manners." In 2007, Brooks and Jean-Marie interviewed Black administrators in an urban high school in the southeastern United States that recalled White administrators attributing low test scores Black students received on achievement exams the result of the Black students not caring.

\section{Implications for Theory and Research}

Chapter II included the description of two theories. The theories were CRT and CCW. How CRT and CCW relates to the findings in this study is considered in the following sections.

\section{Critical Race Theory and Community Cultural Wealth}

The tenets of Ladson-Billings and Tate's (1995) CRT and Yosso's (2005) CCW were evident in this study. Black administrators' voices were one of the most significant parts of this study. This study suggests racism still exists and is embedded within U.S. society and the 
experiences of the Black administrator. In Chapter I, I described the unintended consequences of the Civil Rights movement: the devastating damage to the role of the Black administrator wherein Black administrators were no longer offered legitimate administrative roles or not offered administrative roles at all. Finally, participants shared the need for culturally responsive practices and policies still exists because current practices and policies perpetuate unequitable learning environments for BIaLS.

Four themes emerged during the second phase of the study: (a) describing self: identifying the individual, (b) exploring advantages of being Black: drive and perseverance, (c) navigating administrative roles: service and competencies, and (d) encountering racism. Each of the themes have connections with one of the five tenets of CRT. The onus of this study originates from the centrality of experiential knowledge and the transdisciplinary perspective tenets of CRT which speak of giving voice to those marginalized in society. Through their responses related to the theme of navigating administrative roles: service and competencies Black administrators reported storytelling was part of their administrative roles when acting as role models and change agents. Further, through this study participants were able to share their experiences related to marginalization due to racism.

The CRT tenet of the intercentricity of race and racism with other forms of subordination was evident in this study. Through their responses, participants shared how White privilege acted as a barrier. First, participants shared White privilege made it difficult for them to enter certain spaces and to be accepted as a competent administrator as shown in the describing self: identifying the individual theme. Second, respondents also shared that Whiteness sometimes led to biased and racist actions from their colleagues, faculty and staff as found in the themes exploring advantage of being Black: drive and perseverance and encountering racism. Further, 
several respondents reported being undervalued, being excluded by their White colleagues, and feelings of isolation. They also reported feeling as their work was more closely scrutinized than that of their White colleagues. These barriers all illustrate how the CRT tenets the intercentricity of race and racism with other forms of subordination and the challenge to dominate ideology are evident in public schools in the United States.

The losses Black educators endured during the integration of schools during the Civil Rights Movement after Brown v. Board of Education (1954) is still evident today. Black educators, especially Black administrators, are so few in number which is directly related to the loss of Black educators' positions in the 1960s. The CRT tenet of the commitment to social justice posits that White people are the primary beneficiary of Civil Rights Movement. In this study, participants spoke about the small number of Black educators currently serving in administrative roles. Today, Black educators are still reeling from the unintended negative consequences of the integration of public schools in the United States during the Civil Rights Movement.

Ladson-Billing's and Tate's (1995) CRT in education encompasses the tenet of the challenge to dominate ideology that suggests colorblindness allows society to ignore racist policies. This study found that one of the barriers Black administrators encounter is the lack of culturally responsive teaching practices and policies in PK-12 public schools in the United States This and previous studies found that Black administrators endure racism within many facets of their administrative roles including the disparate treatment of BIaLS. For example, according to LaForett and DeMarco (2019) the disproportionate rate at which BIaLS are subjected to exclusionary discipline is an indicator of racism in the educational system at an institutional level. 
The five tenets of CRT are evident through the lived experiences of the participants in this study. Racism, Whiteness, and colorblindness have negatively influenced the experience of Black administrators serving in PK-12 public schools in the United States. Participants described using the six forms of cultural capital found in Yosso's (2005) theory of CCW. In this study, the forms of cultural capital were used to frame the participants' experiences as Black administrators. The results of this study revealed participants had positive experiences related to five of the forms of cultural capital: (a) aspirational, (b) familial, (c) navigational, (d) resistant, and (e) social.

This study explores how possession of cultural capital as defined in Yosso's (2005) theory of CCW affects how Black administrators navigate their roles. The Black administrators in this study were able to use their cultural capital to overcome barriers, such as racism encountered, while trying to create culturally responsive policies and practices. The ability to leverage their cultural capital served their students well. Further, participants reported acting as a stimulus for the development of cultural capital within their students and attempting to positively influence the growth of those capitals. For example, one participant spoke about helping students navigate the educational environment to access tutoring, after school programs and other local resources all which are part of nurturing students' navigational capital. The realization that Black administrators are actively working to encourage cultural capital in students could potentially be an integral part of the systemic implementation of culturally responsive teaching and practices because students will be better able to self-advocate for their needs if prepared to be intentional about the use of their cultural capital. 


\section{Implications for Practice}

First, professional development related to culturally responsive teaching and practices must be provided. Prior research has shown teacher preparatory programs at times sustain teacher bias (Allen et al., 2013; Howard, 2014; Miller, 2015; Nash \& Miller, 2015). This fact alone is grounds for timely professional development that addresses the negative outcomes of teacher bias that manifests itself in the educational environment. In addition, this need for this professional development is directly related to the negative affects White teacher bias has on the academic achievement of BIaLS.

Second professional development related to culturally responsive teaching and practices is necessary to illuminate the reality that culturally responsive teaching does not rest solely on Black educators is necessary because $90 \%$ of the teaching force is White. Black teachers comprise only $7 \%$ of U.S. public school teachers (U.S. Department of Education, NCES and OCR, 2016b). This professional development is necessary to provide teachers with the knowledge and skills to implement culturally responsive teaching practices in their classrooms. Further, racial bias must be addressed during professional development because the negative effects of bias are numerous. Racial bias, whether conscious or unconscious, effects teachers' ability to effectively implement culturally responsive teaching practices which leads to disparate treatment of BIaLS in several different areas.

Previous research suggests teacher bias plays a role in the disproportionate number of BIaLS in special education, exclusionary discipline, and gifted classes (Fergus, 2017). In addition, racial bias makes it difficult for Black administrators to be appointed to leadership roles and lead effectively. In fact, Black leaders represent only approximately $10 \%$ of principals in the U.S according to the NCES (2016c). 
Second, for Black administrators to be able to create culturally responsive practices and policies, barriers that currently exist must be removed. Previous research suggests numerous barriers exist including: (a) community (Henderson, 2015; Loder, 2005), (b) distrust (Brooks \& Jean-Marie, 2003; Loder, 2005), (c) race and racism (Bloom \& Erlandson, 2003; Henderson, 2015; Moore, 2013), (d) stereotypes (Brooks \& Jean-Marie, 2003; Henderson, 2015; Moore, 2013), and others. Analysis of data in this study found some additional barriers encountered by Black administrators such as feelings of isolation and marginalization. In addition, the lack of cultural competency was evident in analysis of the qualitative data. Madeline and Stephanie described the time consuming nature of the work required to increase the cultural competence of a predominately White teaching staff. This is significant as previous literature supports the connection between cultural competence and successful outcomes for students (RobinsonZanartu et al., 2011; Rogers \& Lopez, 2002).

Third, the systemic racist and biased policies and practices that exist in the PK-12 public school setting in the United States must be addressed. As stated previously, previous research suggests Black administrators cite race and racism (Bloom \& Erlandson, 2003; Henderson, 2015; Moore, 2013) as barriers they have encountered throughout their administrative tenures. It is difficult to create culturally responsive policies and practices when bias remains. Previous research suggests it is not uncommon for teachers to carry bias that negatively impacts Black students (Mary et al., 2018). Further, Madeline and Stephanie both recounted spending significant amounts of time providing support to White teachers and colleagues to address the negative impact of racist policies against BIaLS and their families. This study suggests the onus of teaching anti-racism often falls upon the Black administrator. 
Fourth, participants spoke of the positive experience of being able to share lived experiences with other Black educators, more specifically Black administrators. It would be beneficial for Black administrators to be placed into cohorts with other Black administrators. These pairings will allow them the benefit of shared experiences, the camaraderie of colleagues, and potentially acquiring new skills or knowledge centered around culturally responsive teaching practices. This experience could potentially allow Black administrators a space and opportunity to identify ways to address the inequitable school experiences of BIaLS including: (a) school discipline, (b) lack of access, (c) lower academic achievement, and (e) overrepresentation in special education.

Finally, data from this study suggest Black administrators are able to form connections with BIaLS from having shared lived experiences. It is important to take advantage of those shared experiences to create meaningful, relevant curricula as part of culturally responsive practices. Those connections also allow Black administrations to form relationships with BIaLS which creates a sense of belonging that is critical for students to experience academic successes.

\section{Limitations}

First, this study analyzed data from 42 Black administrators. While the data gathered from these participants has the potential to add to the extant research, it is paramount to explore the experiences of as many Black administrators as possible. This will lead to a more accurate depiction of their experience of the Black administrator which can lead to identifying ways to support them in their efforts to create equitable learning experiences for BIaLS.

Second, none of the participants were administrators in the early childhood setting. Further, only one participant was a district administrator. Therefore, the findings in this study may not be generalized to the district or early childhood setting. During the development of the 
survey I did not conduct reliability or validity. Also, there was no statistical analysis completed to verify the reliability or validity of the survey results. It is important to consider these limitations when examining the findings.

Third, only two participants were interviewed in the second phase of the study. While the two participants contributed very timely, valuable details and explanation one must be careful to consider the qualitative data represents the experience of only two administrators serving as building principals.

\section{Recommendations for Future Research}

While the transformative explanatory sequential mixed methods design was appropriate for this study, a grounded theory study could potentially create new theory with which to frame future studies related specifically to the experience of the Black administrator. As stated previously, there is little extant research on this topic and the provision of novel theories by which to frame new research would encourage future researchers to explore the topic of the Black administrator's experiences thereby adding to the body of research on that topic.

Another study that could add to the body of research related to the experience of the Black administrator would be a study considering the positive changes to the implementation of culturally responsive practices and policies, if any, that occur when Black administrators are placed in cohorts with other Black administrators that act as professional learning communities. Administrators in this study reported working with other Black administrators was a good experience because of shared lived experiences. Perhaps that practice can be maximized by creating learning communities with the objective of creating culturally responsive environments. 


\section{Conclusion}

Black administrators continue the tradition of excellence in education nearly six decades after the Civil Rights Movement forever altered the trajectory of Black educators in the United States. Most Black administrators utilize five of the six forms of Yosso's (2005) cultural capital. The five tenets of CRT are evident as Black administrators navigate their roles in PK-12 public schools in the United States. Yet, the participants of this study exhibited resilience, individualism, advocacy and a willingness to persevere to create equitable learning experiences for BIaLS through culturally responsive practice and policies.

Considering the fact PK-12 classrooms in the United States are more ethnically diverse than ever before, it is alarming that Black educators and administrators are so few. First, teacher preparation for providing culturally responsive learning environments must be improved. Second, Black educators must be recruited to increase the number of Black educators in the field. Third, Black educators must be provided with genuine leadership opportunities.

The results of this study revealed four themes related to the Black administrators' experience. The four themes were: (a) describing self: identifying the individual, (b) exploring the advantages of being Black: drive and perseverance, (b) navigating administrative roles; service and competencies, and (d) encountering racism. The first theme encompassed very personal subthemes such as race, class and values, and personality. Participants shared how their Blackness, upbringing and middle-class values directly influenced how they navigated their administrative roles.

Participants in this study exhibited a drive to create equity and perseverance to stay the course despite encountering numerous barriers. These experiences are encompassed in the second theme: exploring the advantages of being Black: drive and perseverance. Participants had 
a strong drive to use their administrative positions to support BIaLS. Their tenacity, ability to overcome and strong perseverance aloud the participants to live some positive experiences. More importantly, these characteristics empowered them to overcome barriers encountered while trying to create equitable learning environments during their tenures.

The barriers that were encountered by the participants in this study were numerous as explored in the third and fourth themes: navigating administrative roles: service and competencies and encountering racism. This study revealed challenges related to race and marginalization. Racism presented a challenge in the form of participants' competence being questioned, excessive disciplinary action taken against BIaLS, and parents questioning participants' administrative abilities.

In this study, participants shared their lived experiences while navigating their administrative roles. They shared the sense of responsibility to do the work of supporting BIaLS and the skills required to create culturally responsive practices and policies. The shared experience Black administrators had with BIaLS served as a connection between the administrator and the students.

Relatively few public-school administrators are Black. Data collected in this study suggests Black administrators possess the cultural capital necessary to successfully fulfill administrative roles. However, stereotypical and racist perceptions present barriers that make it difficult for Black educators to become administrators. Once in an administrative role, Black administrators continue to encounter numerous barriers. This is a call to action to provide systemic educational equity for BIaLS through culturally responsive policies and practices! Black educators must be given the opportunity to become administrators and then be supported in environments free of racist and biased perceptions while they navigate those roles. 


\section{REFERENCES}

Albers, P. (2002). Praxis II and African American teacher candidates (or is Everything Black Bad?) English Education, 34, 105-125.

Albert Shanker Institute. (2015). The state of teacher diversity in American education. Retrieved on February 6, 2020 from http://www.shankerinstitute.org/resource/teacherdiversity

Aleman, E. (2009). Through the prism of critical race theory: Niceness and Latina/o leadership in the politics of education. Journal of Latinos and Education, 8, 290-311. doi:10.1080/15348430902973351

Allen, A., Scott, L. M., \& Lewis, C. W. (2013). Racial microaggressions and African American and Hispanic students in urban schools: A call for culturally affirming education. Interdisciplinary Journal of Teaching and Learning, 3, 117-129.

American Psychological Association (2006). Are zero tolerance policies effective in the schools? Retrieved on January 17, 2020 from https://www.apa.org/pubs/info/reports/zerotolerance.pdf

Au, K. (2009). Isn't culturally responsive instruction good teaching? Social Education, 73(4), $179-183$.

Auerbach, C. F., \& Silverstein, L. B.(2003). Qualitative data: An introduction to coding and analysis. New York, NY: New York University Press.

Aud, S., Fox, M., \& KewalRamani, A. (2010). Status and trends in the education of racial and ethnic groups (Report No. NCES 2010-015). U.S. Department of Education, National Center for Education Statistics. EDS510909. Washington, DC: U.S. Government Printing Office. Retrieved December 22, 2019 from https://nces.ed.gov/pubs/2010/2010015.pdf 
Battey, D. \& Leyva, L. (2016). A framework for understanding whiteness in mathematics education. Journal of Urban Mathematics, 9(2), 49-80.

Battle, S. (2017). White teachers' reaction to the racial treatment of middle-school Black boys. IAFOR Journal of Education, 5, 197-217. doi:10.22492/ije.5.2.10

Bireda, S., \& Chait, R. (2011). Increasing teacher diversity strategies to improve the teacher workforce. Center or American Progress. Retrieved on February 6, 2020 from https://files.eric.ed.gov/fulltext/ED535654.pdf

Blanchett, W. J. (2006). Disproportionate representation of African American students in special education: Acknowledging the role of White privilege and racism. Educational Researcher, 35(6), 24-28. doi: 10.3102/0013189x035006024

Bloom, C. M., \& Erlandson D. A. (2003). African American women principals in urban schools: realities, (re)constructions, and resolutions. Education Administration Quarterly, 39,339369. doi: $10.1177 / 0013161 \times 03253413$

Bonilla-Silva, E. (2006). Racism without racists: Color-blind racism and persistence of racial inequality in America. Lanham, MD: Rowman \& Littlefield

Boske, C. A. (2010). I wonder if they had ever seen a black man before?" Grappling with issues of race and racism in our own backyard. Journal of Research on Leadership Education, 5, 248-275. doi:10.1177/194277511000500701

Bradbury, A. (2013). From model minorities to disposable models: The deligimisation of educational success through discourse of authenticity. Discourse: Studies in the C cultural Politics of Education, 34, 548-561. doi:10.1080/01596306.2013.822618 
Brayboy, B. M. J., Castagno, A. E., \& Maughan, E. (2007). Equality and justice for all?

Examining race in education scholarship. Review of Research in Education, 31, 159-194. doi: 10.3102/0091732x07300045

Brooks, J. S., \& Jean-Marie, G. (2007). Black leadership, white leadership: Race and race relations in an urban high school. Journal of Educational Administration, 45, 756-768. doi:10.1108/09578230710829928

Brown v. Board of Education, 347 U.S. 483 (1954).

Brown, F. (2005). African Americans and school leadership: an introduction. Educational Administration Quarterly, 41, 585-590. doi:10.1177/0013161x04274270

Brown, I. A., Davis, T. J., \& Kulm, G. (2011). Pre-service teachers' knowledge for teaching algebra for equity in the middle grades: A preliminary report. The Journal of Negro Education, 80, 266-283.

Brubaker, D. L., \& Coble, L. D. (2007). Staying on Track: An educational leader's guide to preventing derailment and ensuring personal and organizational success. Thousand Oaks, CA: Corwin Press.

Bruce, A. J. (2015). On being White: A raw honest conversation. Children and Libraries, 36, 119-131. doi: 10.5860/cal.13n3.3

Bryan, N. (2017). White teachers role in sustaining the school-to-prison pipeline: Recommendations for teacher education. The Urban Review, 49, 326-345. doi: $10.1007 / \mathrm{s} 11256-017-0403-3$ 
Buck, G., Cook, K., Quigley, C. F., Eastwood, J., Lucas, Y. (2009). Profiles of urban, low ses, African American girls' attitudes toward science: A sequential explanatory mixed methods study. Journal of Mixed Methods Research, 3, 386-410. doi:

$10.1177 / 1558689809341797$

Capper, C. A. (2015). The $20^{\text {th }}$-year anniversary of critical race theory in education: Implications $10.1177 / 0013161 \times 15607616$

Card, D., \& Giuliano, L. (2014). Does gifted education work? For which students? Cambridge, MA: National Bureau of Economic Research. Research Report \#20453. Retrieved on February 7, 2020 from https://www.nber.org/papers/w20453

Carey, R. L. (2015). Desensationalizing Black males: Navigating and deconstructing extreme imageries of Black males and masculinities. In K.J. Fasching-Varner \& N.D. (Eds.), The assault on communities of color: Reactions and responses from the academy (pp. 153157). Lanham, MD: Rowman and Littlefield.

Caruth, G. D. (2013). Demystifying mixed methods research design: A review of the literature. Mevlana International Journal of Education, 3, 112-122. doi:10.13054/mije.13.35.3.2

Casey, L. (2004). Still separate, still unequal: The continuing struggle for racial justice in American education. Leo Dissent, 51, 117-125.

Castagno, A. E., \& Brayboy, B. M. J. (2008). Culturally responsive schooling for indigenous youth: A review of the literature. Review of Educational Research, 78, 941-993. doi:10.3102/0034654308323036

Charmez, K. (2008). Grounded theory. In J.A. Smith (Ed.), Qualitative psychology: A practical guide to research methods ( $2^{\text {nd }}$ ed., pp. 81-1100. London: Sage Publications. 
Chin, E. \& Young, J. W. (2007). A person-oriented approach to characterizing beginning teachers in alternative certification programs. Educational Researcher, 36, 74-83. doi: $10.3102 / 0013189 \times 07299192$

Chiu. C. L., Sayman, D., Carrero, K. M., Gibbon, T., Staci, M., \& Lusk, M. (2017). Developing culturally competent preservice teachers. Multicultural Perspectives, 19, 47-52. doi:10.1080/15210960.2017.1267515

Chubbock, S. (2004). Whiteness enacted, whiteness disrupted: The complexity of personal congruence. American Educational Research Journal, 41, 301-333. doi:10.3102/00028312041002301

Clewell, B. C., \& Villegas, A.M. (2001). Ahead of the class: Design lessons from the DeWitt Wallace-Reader's Digest Fund's Pathways to Teaching Careers Initiative. Washington, DC: Urban Institute.

Condron, D. J., Tope, D., Steidl, C. R., \& Freeman, K. J. (2013). Racial segregation and the Black/White achievement gap, 1992-2009. The Sociological Quarterly, 54(2013), 130157. doi:10.1111/tsq. 12010

Corra, M., Carter, J. S., \& Carter, S. K. (2011). The interactive impact of race and gender or high school advanced course enrollment. The Journal of Negro Education, 80, 33-46.

Couper, M. P. (2000) Web surveys: A review of issues and approaches. The Public Opinion Quarterly, 64, $464-494$.

Creswell, J. W. (2014). Research design: Qualitative, quantitative, and mixed methods approaches ( $4^{\text {th }}$ ed.). Thousand Oaks, CA: Sage Publications.

Creswell, J. W., \& Garrett, A. L. (2008). The movement of mixed methods research and the role of educators. South African Journal of Education, 28, 321-333. 
Cronbach, L. J. (1951). Coefficient alpha and the internal structure of tests. Psychometrika, 16, 297-334.

Daniel, S. M. (2016). Grappling with culturally responsive pedagogy: A study of elementarylevel teacher candidates' learning across practicum and diversity coursework experiences. The Urban Review, 48, 579-600. doi: 10.1007/s11256-016-0369-6

Darling-Hammond, L. (2000). Recruiting teachers for the $21^{\text {st }}$ century: The foundation for educational equity. Journal of Negro Education, 68, 254-279. doi:10.2307/2668100

Darling-Hammond, L. (2003). Keeping good teachers: why it matters, what leaders can do. Educational Leadership, 60(8), 6-13.

Darling-Hammond, L. (2013). Inequality and school resources: What it will take to close the opportunity gap. In P. L. Carter \& K. G. Welner (Eds.), Closing the opportunity gap: What America must do to give every child an even chance (pp. 77-97). New York, NY: Oxford University Press.

Davis, J., Anderson, C., \& Parker, W. (2019). Identifying and supporting black male students in advanced mathematics courses throughout the k-12 pipeline. Gifted Child Today, 42, 140-149. doi:.1177/1076217519842234

Decuir, J., \& Dixson, A. (2004). "So when it comes out, they aren't that surprised that it is there": Using critical race theory as a tool of analysis of race and racism in education. Educational Researcher, 33, 26-31. doi: 10.3102/0013189x033005026

Delcourt, M. A. B., Cornell, D. G., \& Goldberg, M. D. (2007). Cognitive and affective learning outcomes of gifted elementary school students. Gifted Child Quarterly, 51, 359-381. doi:10.1177/0016986207306320 
Dever, B. V., Raines, T. C., Dowdy, E., \& Hostutler (2016). Addressing disproportionality in special education using a universal screening approach. The Journal of Negro Education, 85, 59-71. doi:10.7709/jnegroeducation.85.1.0059

DiAngelo, R. (2011). White fragility. The International Journal of Critical Pedagogy, 3(3), 5470.

Diemer, M. A., Marchand, A. D., McKellar, S. E., \& Malanchuk, O. (2016). Promotive and corrosive factors in African American students' math beliefs and achievement. Journal of Youth and Adolescence, 45, 1208-1225. doi: https:10.1007/s10964-016-0439-9

Dixson, A. D. (2018). "What's going on?: A critical race theory perspective on Black lives matter and activism in education. Urban Education, 53, 231-247. doi:10.1177/0042085917747115

Dixson, A. D., \& Anderson C. R. (2018). Where are we? Critical race theory in education 20 years later. Peabody Journal of Education, 93, 121-131. doi:10.1080/0161956x.2017.1403194

Echols, C. (2006). Challenges facing Black American principals: A conversation about coping. Universal Journal of Educational Research, 4, 192-199.

Embrick, D. G., Dominguez, S., \& Karsak, B. (2017). More than just insults: Rethink sociology’s contribution to contribution to racial microaggressions. Sociological Inquiry, 87, 193-206. doi: 10.1111/soin.12184

Eubanks, S., \& Weaver, R. (1999). Excellence through diversity: Connecting the teacher quality and teacher diversity agendas. Journal of Negro Education, 68, 451-9. doi: $10.2307 / 2668116$ 
Farinde-Wu, A. (2018). \#Blackwomenatwork: Teaching and retention in urban schools. Urban Review, 50, 247-266. doi:10.1007/s11256-018-0449-x

Fergus, E. (2016). Social reproduction ideologies: Teacher beliefs about race and culture. In D. Connor, B. Ferri., \& S. Annamma (Eds.), Discrit: Disability studies and critical race theory (pp. 117-127). New York, NY: Teachers College Press.

Fergus, E. (2017). The integration project among white teachers and racial/ethnic minority youth: Understanding bias in school practice. Theory into Practice, 56, 169-177. doi: 10.1080/00405841.2017.1336036

Ford, D. Y. (2014). Segregation and the underrepresentation of Blacks and Hispanics in gifted education: Social inequality and deficit paradigms. Roeper Review, 36, 143-154. doi: $10.1080 / 02783193.2014 .919563$

Ford, D. Y., Grantham, T. C., \& Whiting, G. W. (2008a). Another look at the achievement gap: Learning from the experiences of gifted Black students. Urban Education, 43,216-239. doi: $10.1177 / 0042085907312344$

Ford, D. Y., Grantham, T. C., \& Whiting, G. W. (2008b). Culturally and linguistically diverse students in gifted education: Recruitment and retention issues. Exceptional Children, 74, 289-308. doi: $10.1177 / 001440290807400302$

Ford, D. Y., \& King, Jr., R. A. (2014). No blacks allowed: Segregated gifted education in the context of brown v. board of education. The Journal of Negro Education, 83, 300-310. doi: 10.7709/jnegroeducation.83.3.0300

Foster, L. (2005). The practice of educational leadership in African American communities of learning: context, scope, and meaning. Educational Administration Quarterly, 41, 689700. doi: $10.1177 / 0013161 \times 04274276$ 
Fultz, M. (2004). The displacement of Black educators post-Brown: An overview and analysis. History of Education Quarterly, 44, 11-45. doi:10.1111/j.1748-5959.2004.tb00144.x

Fraenkel, J. R., Wallen, N. E., \& Hyun, H. H. (2014). How to design and evaluate research in education ( $9^{\text {th }}$ ed.). New York, NY: McGraw-Hill Education.

Frankenberg, R. (1993). White women, race matters: The social construction of Whiteness: Minneapolis: University of Minnesota Press.

Gion, C., McIntosh, K., \& Smolkowski, K. (2018). Examination of American Indian/Alaska Native school discipline disproportionality using the vulnerable decision points approach. Behavioral Disorders, 44, 40-52. doi:10.1177/0198742918773438

Goodman, G., Arbona, C., \& de Ramirez, R. D. (2008). High-stakes, minimum-competency exams. How competent are they for evaluating teacher competence? Journal of Teacher Education, 59, 24-39. doi: 10.1177/0022487107309972

Goldring, R., Tate, S., \& Riddles, M. (2014). Teacher attrition and mobility. (NCES 2014-0777). Washington, DC: National Center for Education Statistics. Retrieved December 22, 2019 from https://nces.ed.gov/pubs2014/2014077.pdf

Greene, J. C. (2007). Mixed methods in social inquiry. New York, NY: Jossey-Bass.

Greene, J. C., Caracelli, V. J., \& Graham, W. F. (1989). Toward a conceptual framework for mixed-method evaluation designs. Educational Evaluation and Policy Analysis, 11, 255274. doi: $10.2307 / 1163620$

Grissom, J. A., \& Redding, C. (2016). Discretion and disproportionality: Explaining the underrepresentation of high-achieving students of color in gifted programs. AERA Open, 2, 1-25. doi:10.1177/2332858415622175 
Hammond, Z. (2015). Culturally responsive teaching and the brain: Promoting authentic engagement and rigor among culturally and linguistically diverse students. Thousand Oaks, CA: Sage Publications.

Harrell, S. P. (2000). A multidimensional conceptualization of racism-related stress: Implications for the well-being of people of color. American Journal of Orthopsychiatry, 70, 42-57. doi: $10.1037 / \mathrm{h} 0087722$

Henderson, G. (2015). Leadership experiences of African American male secondary urban principals: The impact of beliefs values, and experiences of school leadership practices. Journal of African American Males in Education, 6(2), 38-54.

Henderson, D. X., Walker, L., Barnes, R. B., Lunsford, A., Edwards, C., Clark, C. (2019). A framework for race related trauma in the public education system and implications on health for black youth. Journal of School Health, 89, 916-933. doi: 10.1111/josh.12832

Henry, K. L., \& Dixson, A. D. (2016). Locking the door before we got the keys: Racial realities of the charter school authorization process in post-Katrina New Orleans. Educational Policy, 30(1), 218-240. doi:10.1177/0895904815616485

Hesse-Biber, S. (2010). Qualitative approaches to mixed method practice, Qualitative Inquiry, 16, 455-468. doi:10.1177/1077800410364611

Heyvaert, M., Maes, B., \& Onghena, P. (2011). Mixed methods research synthesis: Definition, framework, and potential. Quality and Quantity, 47, 659-676. doi:10.1007/s11135-0119538-6

Hodgkin, S. (2008). Telling it all: A story of women's social capital using a mixed methods approach. Journal of Mixed Methods Research, 2, 296-316.

doi:10.1177/1558689808321641 
Hood, S., \& Parker, L. (1991). Minority students informing the faculty: Implications for racial diversity and the future of teacher education. Journal of teacher Education, 45-164-171. doi: $10.1177 / 0022487194045003002$

Howard, T. (2014). Black maled: Perils and promises in the education of African American males. New York, NY: Teacher College Press.

Hotchkins, B. K. (2016). African American males navigate racial microaggressions, Teachers College Record, 118(0603013), 1-36.

Huber, L. P. (2011) Discourses of racist nativism in California public education English dominance as racist nativist microaggressions. Educational Studies, 47, 379-401. doi:10.1080/00131946.2011.589301

Hudiburg, M., Mascher, E., Sagehorn, A., \& Stidham, J. S. (2015). Moving toward a culturally competent model of education: Preliminary results of a study of culturally responsive teaching in an American Indian community. School Libraries Worldwide, 21. 137-148.

Hudson, M., Foster, E., Irvine, J. J., Holmes, B., \& Villegas, A. M. (2002). Tapping potential: Community college students and America's teacher recruitment challenge. Belmont, MA: Recruiting New Teachers.

Ingersoll, R., \& May, H. (2011a). The minority teacher shortage: Fact or fable? Phi Delta Kappan, 93, 62-605. doi: 10.1177/003172171109300111

Ingersoll, R., \& May, H. (2011b). Recruitment, retention and the minority teacher shortage. Consortium for Policy Research in Education. Research Report \# RR-69. doi: 10.12698/cpre.2011.rr69

Janesick, V. J. (2011). "Stretching” exercises for qualitative researchers ( $3^{\text {rd }}$ ed.). Thousand Oaks, CA: Sage Publications. 
Jean-Marie, G. (2013). The subtlety of age, gender, and race barriers: A case study of early career African American female principals. Journal of School Leadership, 23, 615-639. doi: $10.1177 / 105268461302300403$

Johnson, H. B. (2006). The American dream and the power of wealth: Choosing schools and inheriting inequality in the land of opportunity. New York: Routledge.

Johnson, R. B., Onwuegbuzie, A. J., \& Turner, L. A. (2007). Toward a definition of mixed methods research. Journal of Mixed Methods Research, 1, 112-133. doi:10.1177/1558689806298224

Jones, C. (2002). Teachers' perceptions of African American principals. Peabody Journal of Education, 77, 7-34. doi:10.1207/s15327930pje7701_2

Kaoema, J. (2001). Dilemmas of an indigenous academic: A native Hawaiian story. Contemporary Issues in Early Childhood, 2, 67-82. doi:10.2304/ciec.2001.2.1.9

Kang, J. (2012). Communications law: Bits of bias. In J.D. Levinson \& R. J. Smith (Eds.), Implicit racial bias across the law (pp. 132-145). Cambridge, MA: Cambridge University Press.

Kea, C. D., \& Trent, S. C. (2013). Providing culturally responsive teaching in field-based and student teaching experiences: A case study. Interdisciplinary Journal of Teaching and Learning, 3, 82-101.

Knapp, H. (2018). Intermediate statistics using SPSS. Thousand Oaks, CA: Sage Publications. Ladson-Billings, G. (1994). The dreamkeepers: Successful teachers of African-American children. San Francisco: Josey-Bass. 
Ladson-Billings, G. (1998). Just what is critical race theory and what's it doing in a nice field like education? Qualitative Studies in Education, 11, 7-25. doi:10.4324/97804295035042

Ladson-Billings, G. (2005). But that's just good teaching! The case for culturally relevant pedagogy. Theory into Practice, 34, 159-165. doi:10.1080/00405849509543675

Ladson-Billings, G. (2006). From the achievement gap to the education debt: Understanding achievement in US schools. Educational Researcher, 34(7), 3-12. doi:10.3102/0013189x035007003

Ladson-Billings, G. (2010). Just what is critical race theory and what is it doing in a nice field like education? International Journal of Qualitative Studies in Education, 11, 7-24. doi:10.1080/095183998236863

Ladson-Billings, G., \& Tate, W. (1995). Toward a critical race theory of education. Teachers College Record, 97, 47-68. doi: 10.4324/9781315709796-2

Laforett, D.R., \& DeMarco, A. (2019). A logic model for educator level intervention research to reduce racial disparities in student suspension and expulsion. Cultural Diversity and Ethnic Minority Psychology, doi:10.1037/cdp0000303

Lenski, S. D., Crumpler, T. P, Stallworth, S., \& Crawford, K. M. (2005). Beyond awareness: Preparing culturally responsive pre-service teachers. Teacher Education Quarterly, 32, 85-100.

Leonardo, Z. (2002). The souls of white fold: Critical pedagogy, whiteness studies and globalization discourse. Race, ethnicity and education, 10, 261-278. doi: $10.1080 / 13613320120117180$ 
Leonardo, Z. (2004). The color of supremacy: Beyond the discourse of 'white privilege'. Educational Philosophy, 36, 137-152.doi:10.1111/j.1469-5812.2004.00057.x

Levin, H. M. (2009). The economic payoff to investing in educational justice. Educational Researcher, 38, 5-20.

Lewis, A. E. (2004). "What group?" Studying Whites and whiteness in the era of "colorblindness". Sociological Theory, 22, 623-646. doi: 10.1111/j.0735-2751.2004.00237.x

Lewis, A. E., \& Diamond, J. B. (2015). Despite the best intentions: How racial inequality thrives in good schools. Oxford: Oxford University Press.

Lichtman, M. (2013). Qualitative research in education: A user's guide (3 ${ }^{\text {rd }}$ ed.). Thousand Oaks, CA: Sage Publications

Loder, T. L. (2005). African American women principals' reflections on social change, community othermothering, and Chicago public school reform. Urban Education, 40, 298-320. doi:10.1177/0042085905274535

Madkins, T. C. (2011). The Black Teacher Shortage: A literature review of historical and contemporary trends. The Journal of Negro Education, 80, 417-427.

Marks, G. N. (2005). Cross-national differences and accounting for social class inequalities in doi:10.1177/0268580905058328

Marshall, C. (2004). Social Justice Challenges to Educational Administration: Introduction to a special issue. Educational Administration Quarterly, 3-13. doi:

$10.1177 / 0013161 \times 03258139$

Martell, C. C., \& Stevens, K. M. (2017). Becoming a race-conscious social studies teacher: The influence of personal and professional experiences. The Social Studies, 6, 249-260. doi:10.1080/00377996.2017.1391164 
Matthews, D. E., Carey, R. L., Olivarez, A., \& Saeedi, K. M. (2017). Guilty as charged? Principals' perspectives on disciplinary practices and the racial discipline gap. Educational Administration Quarterly, 53, 519-555. doi: 10.1177/0013161x17714844

McBee, M. T. (2006). A descriptive analysis of referral sources for gifted identification screening by race and socioeconomic status. Journal of Secondary Gifted Education, 17, 103-111. doi: 10.4219/jsge-2006-686

McCoy, D. L. Rodricks, D. J. (2015). Critical Race Theory in higher education: 20 years of theoretical and research innovations: ASHE Higher Education Report, volume 41(3), 1117. doi:10.1002/aehe.20021

McCray, C. R., Wright, J. V., \& Beachum, F. D. (2007). Beyond brown: Examining the perplexing plight of African American principals. Journal of Instructional Psychology, $34,247-255$.

McGrady, P. B., \& Reynolds, J. R. (2013). Racial mismatch in the classroom: Beyond Black-

White differences. Sociology of Education, 87, 3-17. doi: 10.1177/0038040712444857

McKown, C. (2013). Social equity theory and racial-ethnic achievement gaps. Child Development, 84, 1120-1136. doi:10.1111/cdev.12033

McNeal, K., \& Lawrence, S. (2009). Teachers from the "neighborhood": Standardized testing as a barrier to certification of minority candidates. In F. L. Uy (Ed.), 2009 Yearbook urban learning, teaching, and research (pp. 1-12). Los Angeles, CA: American Educational Research Association.

Meaney, K. S., Bohler, H. R., Kopf, K., Hernandez, L., \& Scott, L. (2008). Service-learning and pre-service educators' cultural competence for teaching: an exploratory study. Journal of Experiential Education, 31, 189-208. doi:10.5193/jee.31.2.189 
Meece, J.L., \& Kurtz-Costes, B. (2001). Introduction: The schooling of ethnic minority children and youth. Educational Psychologist, 36, 1-7. doi:10.4324/9781410608444

Mensah, F. M. (2013). Theoretically and practically speaking, what is needed in diversity and equity in science teaching and learning? Theory into Practice, 52, 66-72. doi: $10.1080 / 00405841.2013 .743781$

Mensah, F. M. (2019). Finding voice and passion: Critical race theory methodology in science teacher education. American Educational Research Journal, 56, 1412-1456. doi:10.3102/0002831218818093

Mertens, D. M. (2009). Transformative research and evaluation. New York: Guilford Press.

Mikelson, R. A. (2001). Subverting Swann: First-and second-generation segregation in the Charlotte-Mecklenburg schools. American Educational Research Journal, 28, 215-252. doi:10.3102/00028312038002215

Miles, M. B., Huberman, M., \& Saldana, J. (2020). Qualitative data analysis: a methods sourcebook ( $\left.4^{\text {th }} e d.\right)$. Thousand Oaks, CA: Sage Publications.

Miller, E. (2015). Discourses of Whiteness and Blackness: An ethnographic study of three young children learning to be White. Ethnography and Education, 10, 137-152. doi: $10.1080 / 17457823.2014 .960437$

Milner, H. R. (2006). But good intentions are not enough: Theoretical and philosophical the teachers/Diverse classrooms (pp. 79-90) Sterling, VA: Stylus.

Moody, M. (2016). From under diagnoses to over-representation: Black children, ADHD, and the school-to-prison pipeline. Journal of African American Studies, 20, 152-163. doi:10.1007/s12111-016-9325-5 
Moore, C. D. (2013). Race specialists: What a black administrator ought to be and do. Journal of School Leadership, 23, 994-1014. doi:10.1177/105268461302300604

Nash, K., \& Miller, E. (2015). Reifying and resisting racism from early childhood to adulthood. Urban Review, 47, 184-208. doi: 10.1007/s11256-014-0314-5

National Commission on Teaching and America's Future. (1996). What matters most: Teaching for America's future. New York: Author.

Neuman, W. L. (2000). Social research methods ( $4^{\text {th }}$ ed). London: Allyn \&Bacon.

Oliver, M. L., \& Shapiro, T. M. (2006). Black wealth/White wealth: A new perspective on racial inequality (Tenth Anniversary Edition). New York: Routledge.

Ononuju, I. E. (2016). Legacy, loyalty and leadership: Creating a pipeline of indigenous Black educational leaders. Journal of Urban Learning, Teaching, and Research, 12, 99-106.

Pluye, P., \& Hong, Q. N. (2014). Combining the power of stories and the power of numbers: Mixed methods research and mixed studies reviews. The Annual Review of Public Health, 35, 29-45. doi:10.1146/annurev-publhealth-032013-182440

Polit, D. F., \& Beck, C. T. (2006). Essential of nursing research: Methods, appraisal and utilization $\left(6^{\text {th }}\right.$ ed.). Philadelphia, PA: Lippincott Williams \& Wilkins.

Poteat, V. P., \& Spanierman, L. B. (2012). Minor racism attitudes among White students: The role of dominance and authoritarianism and the mediating effects of racial colorblindness. The Journal of Social Psychology, 152(6), 758-774. doi:10.1080/00224545.2012.700966

Price-Dennis, \& Souto-Manning (2011). (Re)Framing diverse pre-service classrooms as spaces for culturally relevant teaching. The Journal of Negro Education, 80, 223-238. 
Puchner, L., \& Markowitz, L. (2015). Do Black families value education?: White teachers, institutional cultural narratives, \& beliefs about African Americans. Multicultural Education, 23, 9-16.

Ravitch, D. (2010). The death and life of the great American school system: How testing and choice are undermining education. New York: Basic Books.

Rector-Aranda, A. (2016). School norms and reforms, critical race theory, and the fairytale of equitable education. Critical Questions in Education, 7(1), 1-16.

Reardon, S. F., \& Robinson, J. P. (2007). Patterns and trends in racial/ethnic and socioeconomic academic achievement gaps. In H. F. Ladd (Ed.), Handbook of research in education finance and policy. New York: Routledge.

Robinson-Zanartu, C., Butler-Byrd, N., Cook-Morales, V., Dauphinais, P., Charley, E., \& Bonner, M. (2011). School psychologists working with Native American youth: Training, competence, and needs. Contemporary School Psychology, 15, 103-115.

Rocco, T., Bliss, L. Gallagher, S., \& Perez-Prado, A. (2003). Taking the next step: Mixed methods research in organizational systems. Informational Technology, Learning, and Performance Journal, 21, 19-29.

Roediger, D. R. (1992). The wages of whiteness: Race and the making of the American working class. New York, NY: Verso.

Rogers, K. B. (2007). Lessons learned about educating the gifted and talented: A synthesis of the research on educational practice. Gifted Child Quarterly, 51, 382-396.

doi:10.1177/0016986207306324 
Rogers, M. R., \& Lopez, E. C. (2002). Identifying critical cross-cultural school psychology competencies. Journal of School Psychology, 40, 115-141. doi: 10.1016/s00224405(02)00093-6

Rowley, R. L., \& Wright, D. W. (2011). No "White" child left behind: The academic achievement gap between Black and White students. The Journal of Negro Education, 80, 93-107.

Rubin, H. J., \& Rubin, I. S. (2012). Qualitative interviewing: The art of hearing data ( $3^{\text {rd }}$ ed.). Thousand Oaks, CA: Sage Publications.

Sablan, J.R. (2019). Can you really measure that? Combining critical race theory and quantitative methods. American Educational Research Journal, 56, 178-203. doi:10.3102\%2F0002831218798325

Saldana, J. (2016). The coding manual for qualitative researchers. Thousand Oaks, CA: Sage Publications.

Salehi, K. \& Golafshani, N. (2010). Commentary using mixed methods in research studies: An opportunity with its challenges. International Journal of Multiple Research Approaches, 4, 186-191.

Sanchez, J., Thornton, B., Usinger, J (2008). Promoting diversity in public education leadership. International Journal of Educational Leadership Preparation, 3(3), 1-10.

Santamaria, L. J. (2009). Culturally responsive differentiated instruction: Narrowing gaps between best pedagogical practices benefiting all learners. Teachers College Record, 111, 214-224. 
Schmeichel, M. (2012). Good teaching? An examination of culturally relevant pedagogy as an equity practice. Journal of Curriculum Studies, 44, 211-231.

doi:10.1080/00220272.2011.591434

Schoonenboom, J., \& Johnson, R. B. (2017). How to construct a mixed methods research design. Kolner Zeitschrift Fur Soziologie Und Sozialpsychologie, 69, 107-131. doi:10.1007/s11577-017-0454-1

Schwartz, J. (2014). Classrooms of special justice: Counter-spaces and young men of color in a ged program. Adult Education Quarterly, 64, 110-127. doi: 10.1177/0741713613513632

Scott, L. A. (2019). Experience of Black male special education teachers: Are alternative licensure programs the desired route for recruitment and preparation? Education and Urban Society, 51, 332-350. doi:1177/0013124517719971

Scott, T. M., Gage, N., Hirn, R., \& Han, H. (2018). Teacher and student race as predictor for negative feedback during instruction. School Psychology Quarterly, 34, 22-31. doi:10.1037/spq000025

Sealey-Ruiz, Y., \& Greene, T. (2015). Popular visual images and the (mis) reading of Black male youth: A case for racial literacy in urban preservice teacher education. Teaching Education, 26(1), 55-76. doi:.1080/10476210.2014.997702

Shedd, C. (2015). Unequal city: Race, schools, and perceptions of injustice. New York: Russell Sage Foundation.

Shen, J., Wegenke, G. L., \& Cooley, V. E. (2003). Has the pubic teaching force become more diversified? Educational Horizons, 81(3), 112-118. 
Skiba, R. J., Poloni-Staudinger, L., Simmons, A. B., Feggins-Azziz, R. \& Chung, C. (2005). Unproven links: Can poverty explain ethnic disproportionality in special education? Journal of Special Education, 39, 130-144. doi: 10.1177/00224669050390030101

Skiba, R. J., Simmons, A. B., Ritter, S., Gibb, A. C., Rausch, M. K., Cuadrado, J. \& Chung, C. (2008). Achieving equity in special education: History, status, and current challenges. Exceptional Children, 74, 264-288. doi: 10.1177/001440290807400301

Skiba, R. J., Chung, C., Trachok, M., Baker, T. L., Sheya, A., Hughes, R. L. (2014). Parsing disciplinary disproportionality: Contributions of infraction, student, and school characteristics to out-of-school suspension and expulsion. American Educational Research Journal, 51, 640-670. doi:.3102/0002831214541670

Skiba, R. J., Horner, R. H., Chung, C., Rausch, M. K., May, S. L., \& Tobin, T. (2011). Race is not neutral: A national investigation of African American and Latino disproportionality in school discipline. School Psychology Review, 40, 85-107.

Skiba, R. J., Michael, R. S., Nardo, A. C., \& Peterson, R. L. (2002). The color of discipline: Sources of racial and gender disproportionality in school punishment. The Urban Review, 34, 317-342. doi:10.1023/a:1021320817372

Sleeter, C. E. (2001). Preparing teachers for culturally diverse schools: Research and the overwhelming presence of whiteness. Journal of Teacher Education, 52, 94-106. doi: $10.1177 / 0022487101052002002$

Sleeter, C. (2007). Preparing teachers for multiracial and historically underserved schools. In E. Frankenberg \& G. Orfield (Eds.), Lessons in integration: Realizing the promise of racial diversity in American schools (pp. 171-189). Charlottesville, VA: University of Virginia Pres. 
Solorzano, D. G., \& Yosso, T. J. (2000). Critical race methodology: counter-storytelling as an analytical framework for education research. Qualitative Inquiry, 8, 23-44. doi:10.1177/1077800402008001003

Solorzano, D. G., \& Delgado Bernal, D. (2001). Examining transformational resistance through a critical race and LatCrit theory framework: Chicana and Chicano students in an urban context. Urban Education, 36, 308-342. doi: 10.1177/0042085901363002

St. Mary, J., Calhoun, M., Tejada, J., \& Jenson, J. M. (2018). Perceptions of academic achievement and educational opportunities among Black and African American youth. Child and Adolescent Social Work Journal, 35, 499-509. doi:10.1007/s10560-018-0538-4

Stinson, D. W. (2011). When the "burden of acting White" is not a burden: School success and African American male students. Urban Review, 43, 43-65. doi:10.1007/s11256-009$0145-y$

Sue, D. W., Lin, A. I., Torino, G. C., Capodilupo, C. M. \& Rivera, D. P. (2009). Racial microaggressions and difficult dialogues on race in the classroom. Cultural Diversity and Ethnic Minority Psychology, 15, 183-190. doi:10.1037/a0014191

Sullivan, A. L., \& Bal, A. (2013). Disproportionality in special education: Effects of individual and school variables on disability risk. Exceptional Children, 79(4), 475-494. doi:10.1177/001440291307900406

Talbert-Johnson, C. (2001). The quest for equity: Maintaining African American teachers in special education. Journal of Negro Education, 70, 286-296. doi: 10.2307/3211281

Talbert-Johnson, C. (2004). Structural inequities and the achievement gap in urban schools. Education and Urban Society, 37, 22-36. doi:10.1177/0013124504268454 
Taliaferro, J. D., \& Decuri-Gunby, J. T. (2008). African American perspectives on the advanced placement opportunity gap. The Urban Review, 40, 164-185. doi:10.1007/s11256-0070066-6

Thomas, M. K. (2004). The SAT II: Minority/majority test-score gaps and what they could mean for college admissions. Social Science Quarterly 85, 1319-1334. doi:10.1111/j.00384941.2004.00278.x

Tillman, L. C. (2003). From rhetoric to reality? Educational administration and the lack of racial and ethnic diversity within the profession. University Council for Educational Review, $14(3), 1-4$.

Tillman, L. C. (2004). (Un)intended consequences?: The impact of the Brown v. Board of Education decision on the employment status of Black educators. Education and Urban Society, 36, 280-303. doi: 10.1177/0013124504264360

Ullucci, K., \& Battey, D. (2011). Exposing colorblindness/grounding color consciousness: Challenges for teacher education. Urban Education, 46, 1195-1225. doi:10.1177/0042085911413150

U.S. Department of Education (2014). Civil rights data collection, 2013-2014: National and state estimations. Retrieved on January 15, 2020 from https://ocrdata.ed.gov/StateNationalEstimations/Estimations_2013_14

U.S. Department of Education (2016a). National Center for Education Statistics. National Teacher and Principal Survey. Retrieved December 18, 2019 from https://nces.ed.gov/surveys/ntps/tables/Principal_raceXgender_Percentage\&Count_toNC ES_091317.asp 
U.S. Department of Education (2016b). National Center for Education Statistics and Office for Civil Rights. Racial, ethnic diversity has grown more quickly among U.S. public school students than teachers. Retrieved on January 12, 2020 from https://www.pewresearch.org/fact-tank/2018/08/27/americas-public-school-teachers-arefar-less-racially-and-ethnically-diverse-than-their-students/ft_18-08-09_teacherrace/

U.S. Department of Education, National Center for Education Statistics. (2016c). Trends in public and private school principal demographics and qualifications: 1987-1988 to 20112012. Retrieved from: https://nces.ed.gov/pubs2016/2016189.pdf

U.S. Department of Education, National Center for Education Statistics. (2018). Status and Trends in the Education of Racial and Ethnic Groups. Retrieved December 18, 2019 from: https://nces.ed.gov/pubs2019/2019038.pdf

U.S. Department of Education, National Center for Education Statistics. (2019a). 2019 Digest of Education Statistics 2018, Table 221.10. Retrieved February 15, 2020 from: https://nces.ed.gov/programs/digest/d18/tables/dt18_221.10.asp

U.S. Department of Education, National Center for Education Statistics. (2019b). 2019 Digest of Education Statistics 2018, Table 222.10. Retrieved February 15, 2020 from: https://nces.ed.gov/programs/digest/d18/tables/dt18_222.10.asp

Valencia, R. R. (2010). Dismantling contemporary deficit thinking: Educational thought and practice. New York: NY: Routledge.

Valverde, L. A. (2003). School leadership for $21^{\text {st }}$ century urban communities. In R.C. Hunter \& F. Brown (Eds.). Challenges of urban education and efficacy of school reform (pp. 187198). Amsterdam: JAI, Elsevier Science. doi:10.1016/s1479-3660(03)80014-8 
Vega, D., Moore, J. L., \& Miranda, A. H. (2015). Who really cares? Urban youths' perceptions of parental and programmatic support. School Community Journal, 25, 53-72.

Villegas, A. M., \& Lucas, T. (2002). Educating culturally responsive teachers: A coherent approach. Albany, NY: State University of New York Press.

Villegas, M., \& Lucas, T. F. (2005). Diversifying the teacher workforce: A retrospective a prospective analysis. In M. A. Smylie \& D. Miretky (Eds.), Developing the teacher workforce: $103^{\text {rd }}$ Yearbook of National Society for the Study of Education Part 1 (pp. 70104). Chicago, IL: University of Chicago Press: doi: 10.1111/j.17447984.2004.tb00031.x

Wachtler, C., \& Troein, M. (2003). A hidden curriculum: Mapping cultural competency in a medical programme. Medical Education, 37, 861-868. doi: 10.1046/j.13652923.2003.01624.x

Wallace, T, \& Brand, B. R. (2012). Using critical race theory to analyze science teachers culturally responsive practices. Cultural Studies of Science Education, 7, 341-374. doi: $10.1007 / \mathrm{s} 11422-012-9380-8$

Watson, D. (2011). “Urban, but not too urban": Unpacking teachers' desires to teach urban students. Journal of Teacher Education, 62, 23-34. doi:10.1177/0022487110379216

Weilbacher, G. (2012). Standardization and whiteness: One and the same? Democracy \& Education, 20(2), 1-6.

Welch, K., \& Payne, A. A. (2018). Latino/a student threat and school disciplinary policy and practices. Sociology of Education, 9, 91-110. doi:10.1177/0038040718757720

Wiggan, G. (2008). From opposition to engagement: Lessons from high achieving African American students. The Urban Review, 40, 317-349. 
Wilkerson, R. D., Wilson, C. M. (2017). "Beating against the wind": The politics of race and retention is supporting African American principal advocacy and growth. Journal of School Leadership, 27, 772-799. doi:10.1177/105268461702700601

Williams, R. B., Bryant-Mallory, D., Coleman, K., Gotel, D., \& Hall, C. (2017). An evidencebased approach to reducing disproportionality in special education and discipline referrals. Children \& Schools, 39, 248-251. doi:10.1093/cs/cdx020

Williams, T. R., Davis L. E., Saunders, J., \& Williams, J. H. (2002). Friends, family, and neighborhood: Understanding academic outcomes of African American youth. Urban Education, 37, 408-431. doi:10.1177/004208502128847423

Yosso, T. J. (2005). Whose culture has capital? A critical race theory discussion of community cultural wealth. Race Ethnicity and Education, 8, 69-91.

doi:10.1080/1361332052000341006

Ziauddin, A, \& Ahn, A. (2018). Teaching for Change: New Teachers' Experiences with and visions for culturally relevant pedagogy. Critical Questions in Education, 9, 22-39. 


\section{APPENDIX A: STUDY THROUGH LENS OF CRITICAL RACE THEORY}

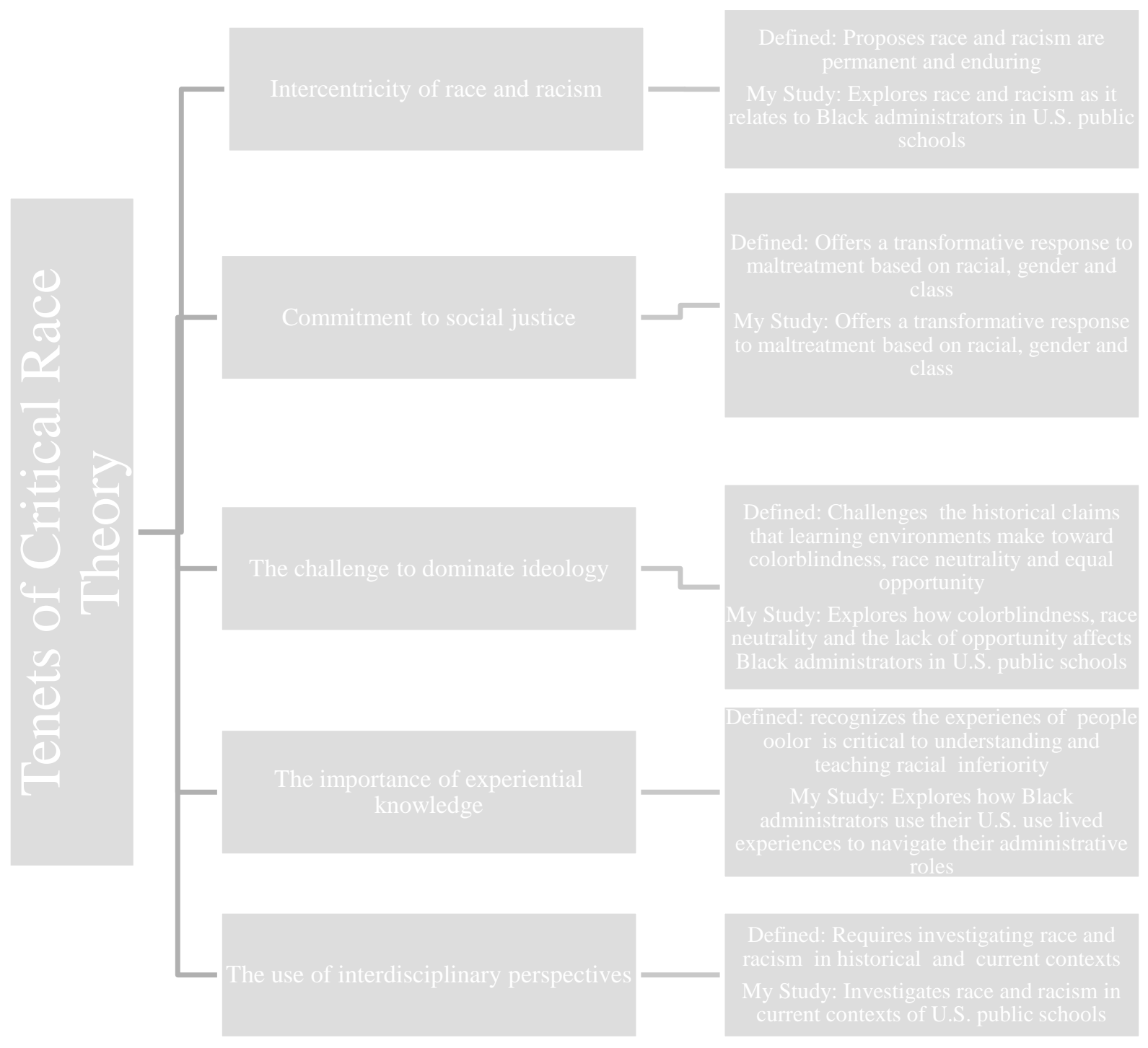

Figure 3. This study through the lens of the tenets of Critical Race Theory and Community Cultural Wealth 
APPENDIX B: SEQUENTIAL EXPLANATORY MIXED METHODS DESIGN

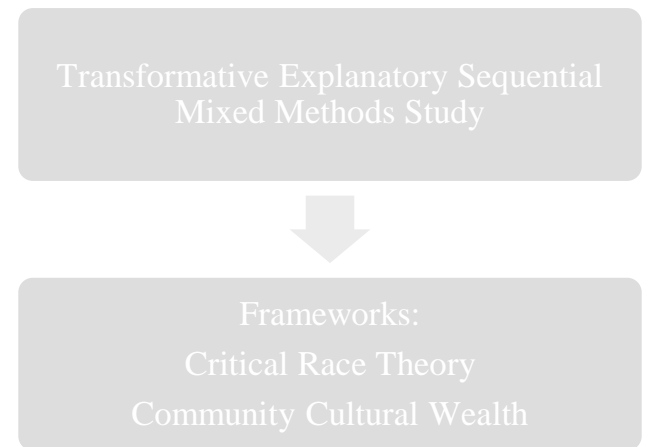

Purpose: To provide a transformative perspective that provides insight into the experiences of the Black administrators in the PK-12 public school setting in the U.S.

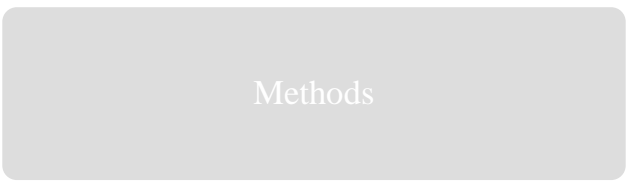

Quantitative Source: Survey containing

multiple choice, Likert Scale, and open ended questions in addition to the collection of demographic data

Qualitative Source: 2 semi-structured interviews of Black administrators serving in U.S. public schools

Quantitative and Qualitative Data Merged and Interpreted

Figure 4. Sequential Explanatory Mixed Methods Research Design 


\section{APPENDIX C: SURVEY}

Please indicate which grade levels you serve (select all that apply).

$\bigcirc$ Early Childhood

Elementary

Middle

Secondary

$\bigcirc$ District

$\square$ Q2 Please select your formal administrative position.

하 $\bigcirc$ Dean

Assistant Principal

Associate Principal

Principal

Director of Special Education

Assistant Superintendent

$\bigcirc$ Superintendent

Other

Q3 Please select your years of administrative experience.

ф. $\bigcirc$ 0-5

6-10

O 11-15

16 or more 


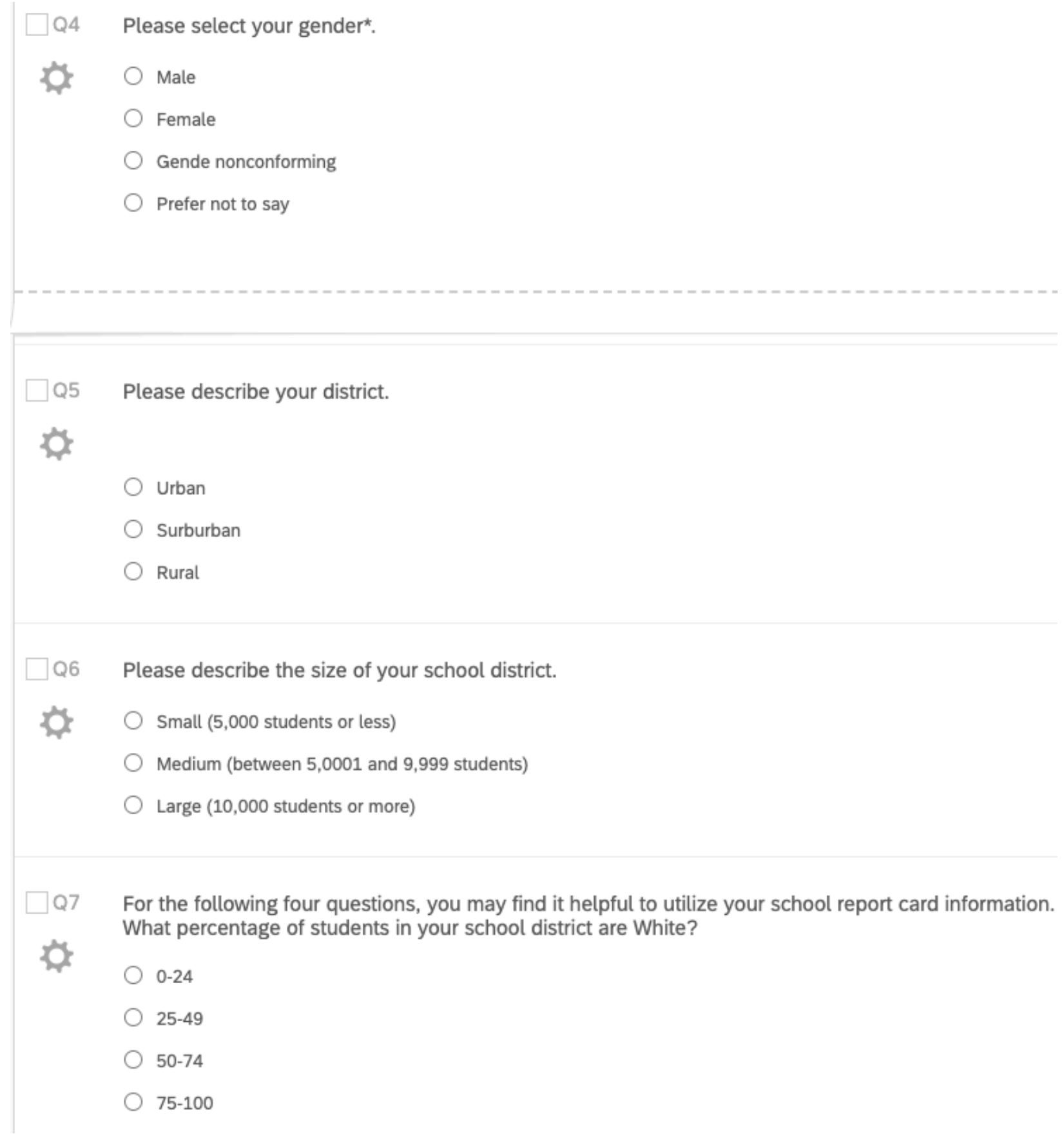




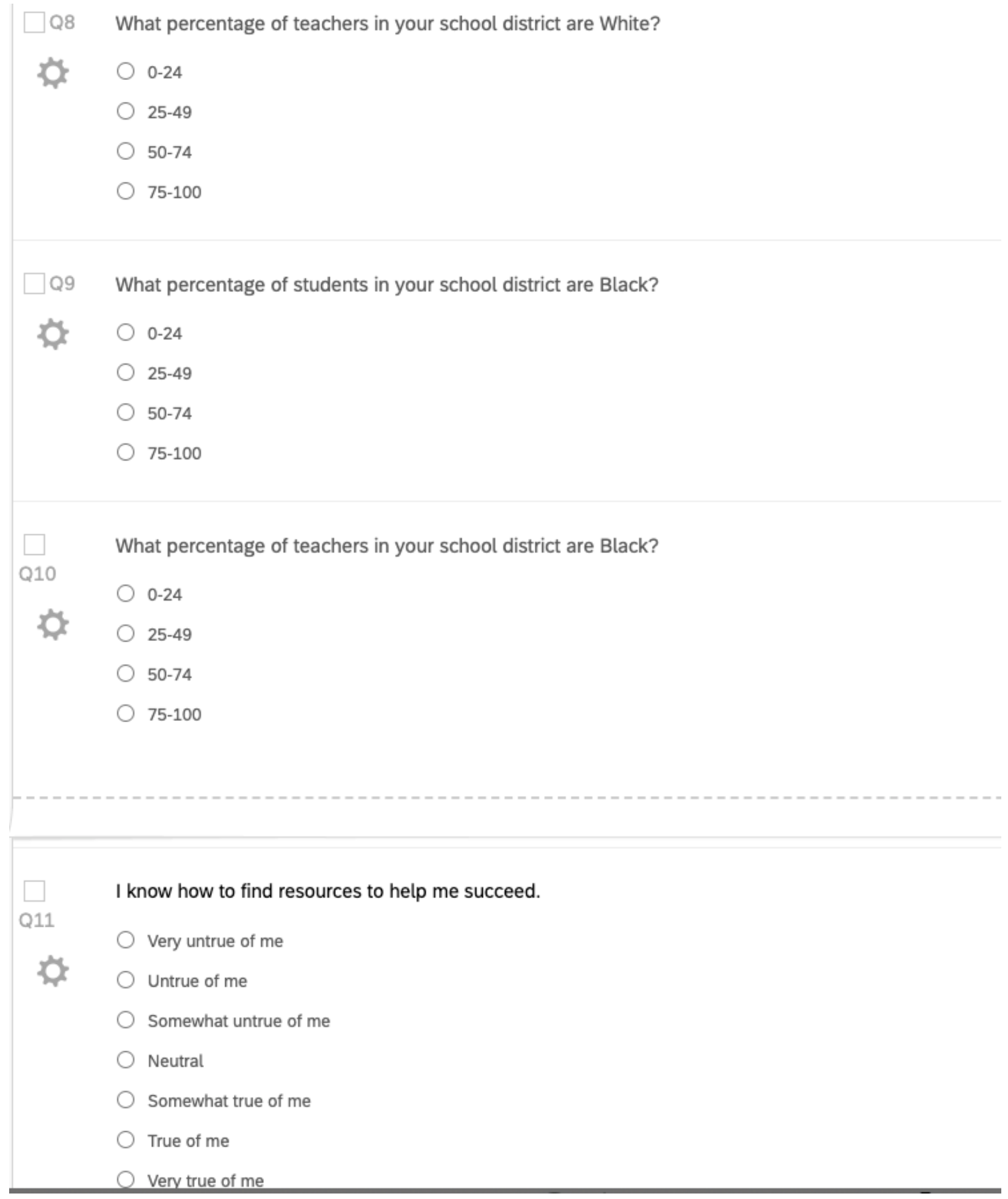




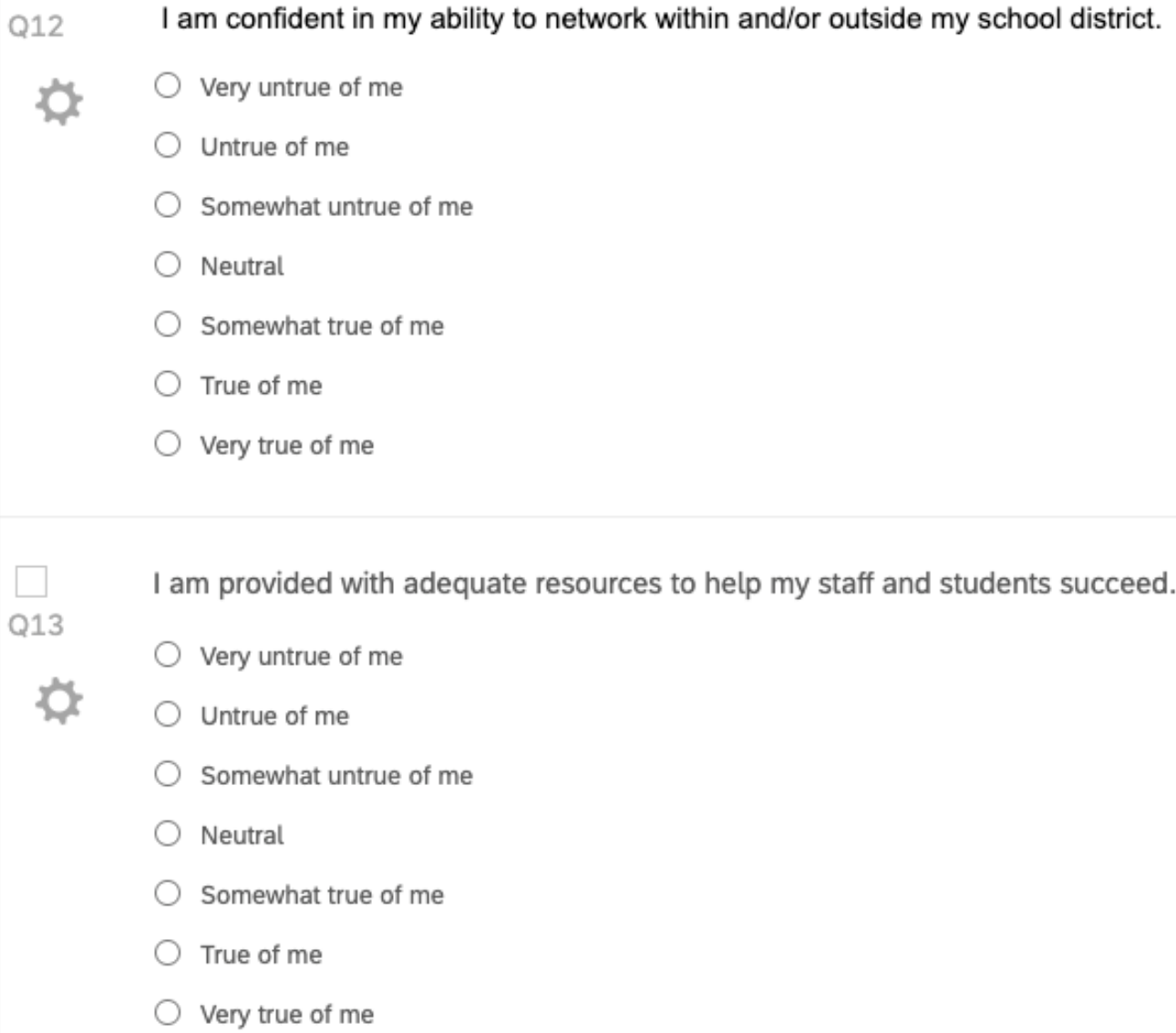


I am confident in my ability to work through conflicts in my school/district.

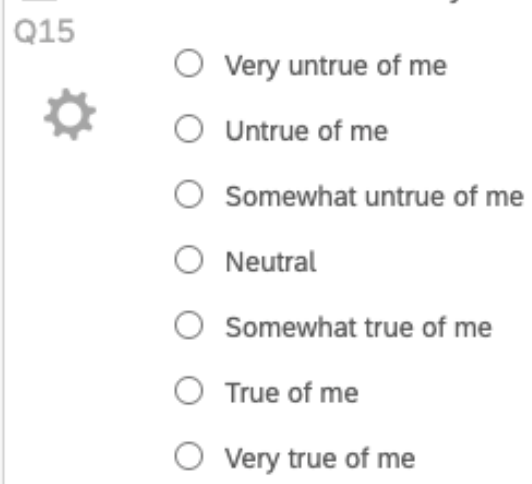




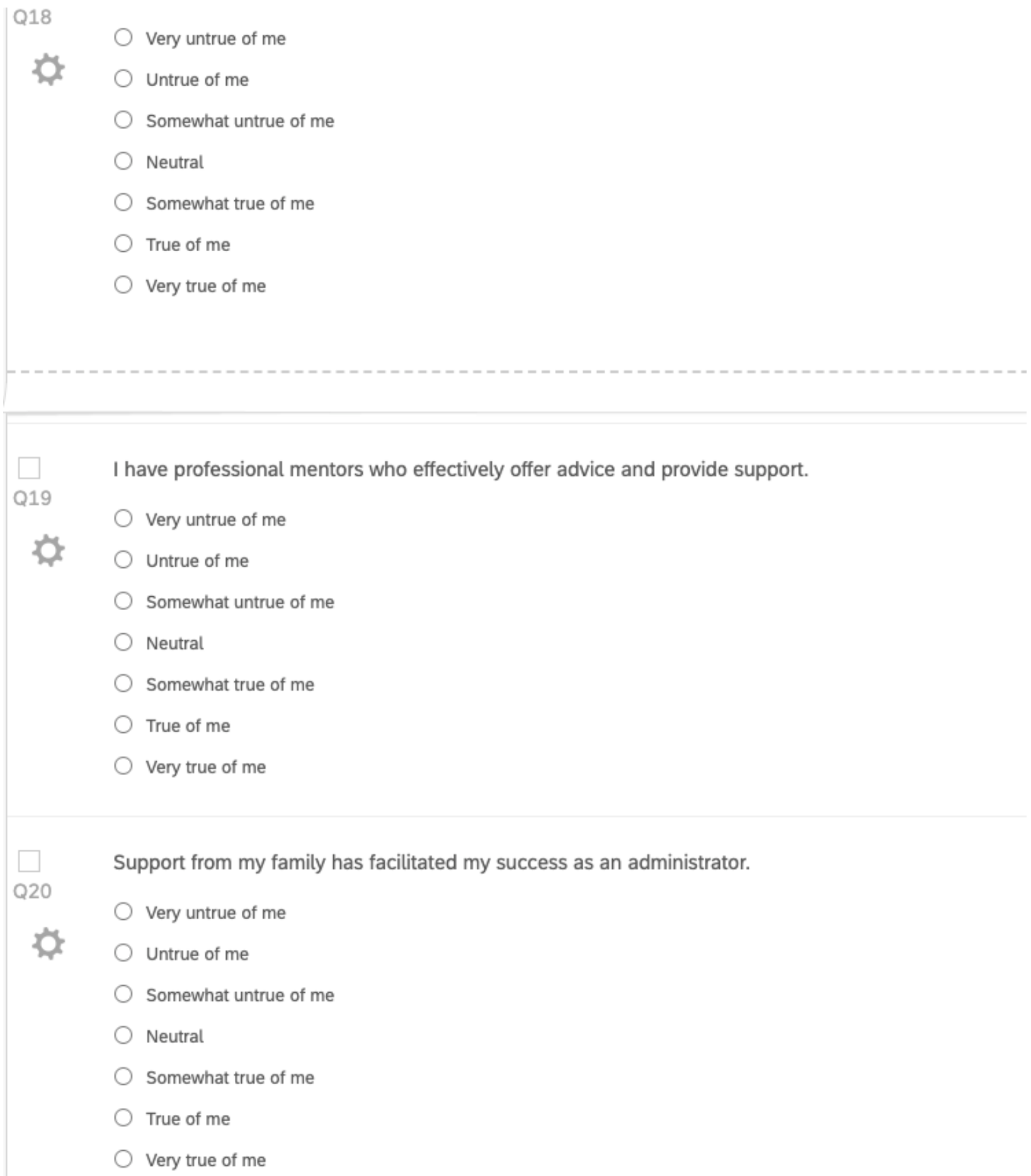




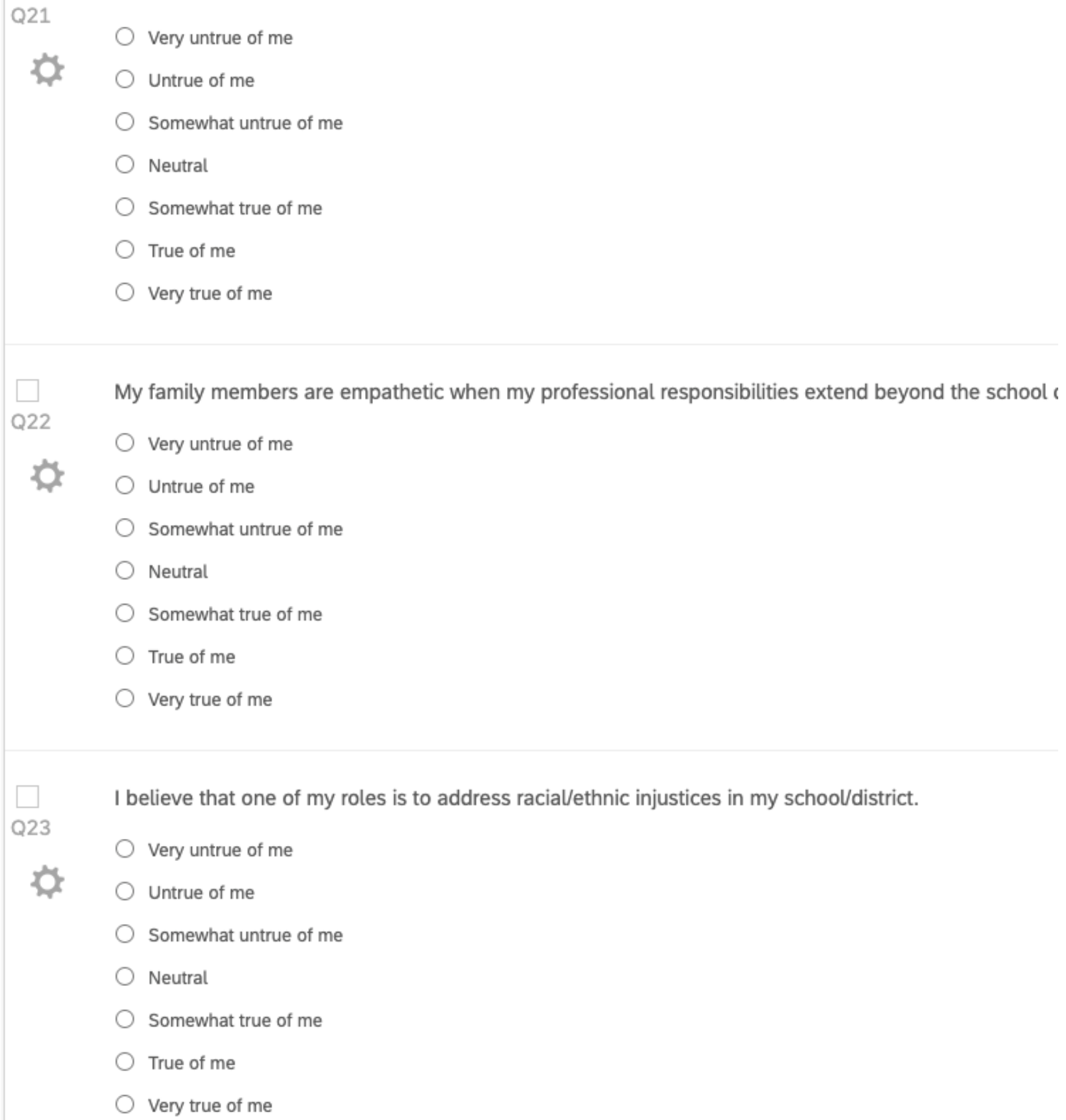




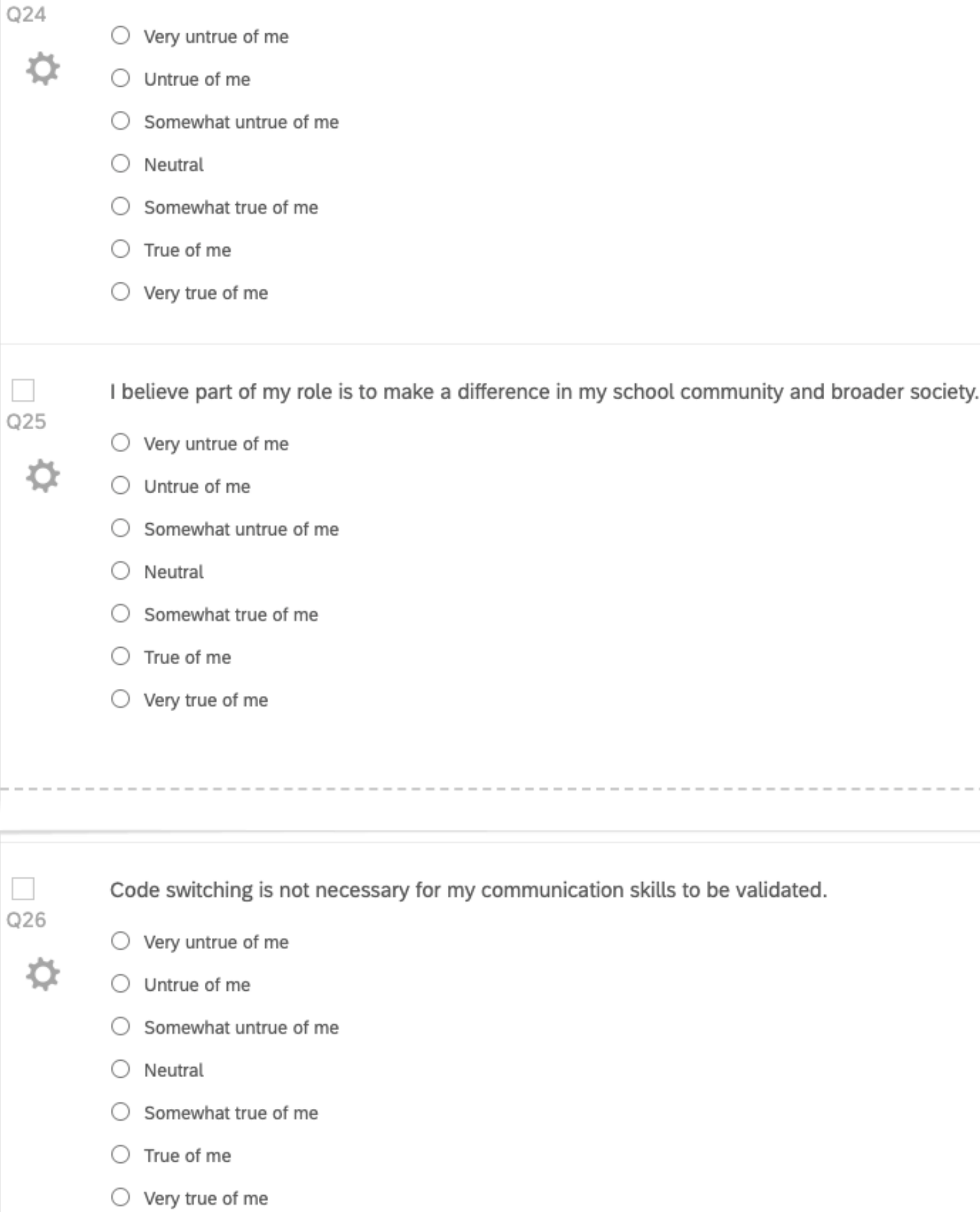




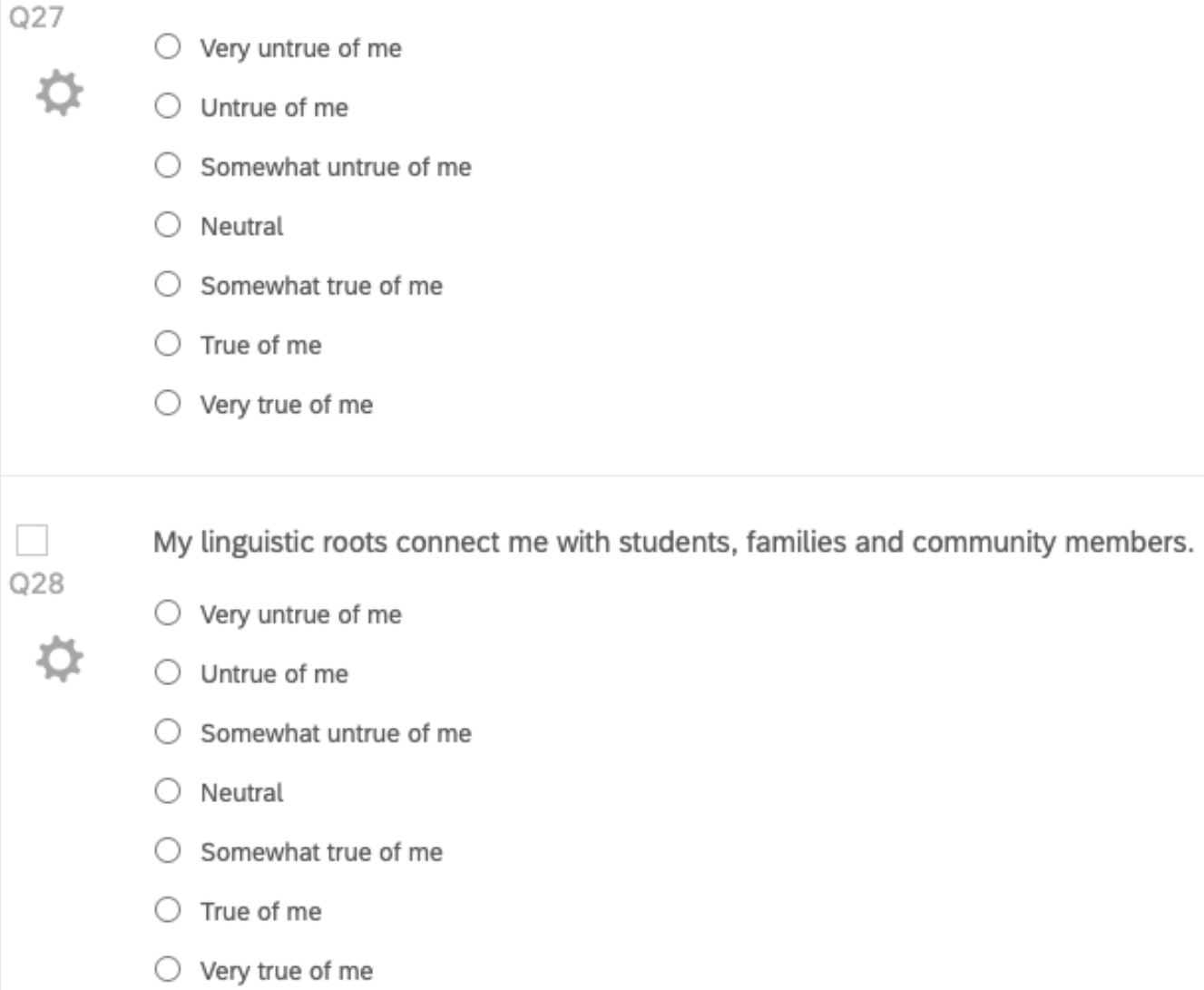


How does or did my Blackness influence my work as an administrator?

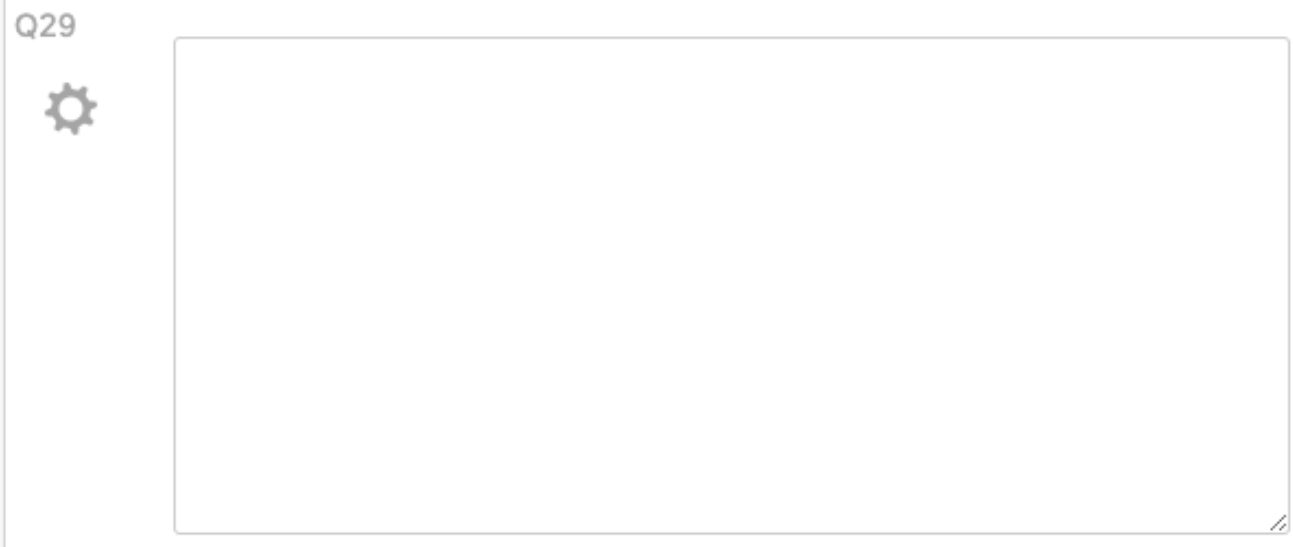

How does or did my Blackness influence how others view my work as an administrator?

Q30

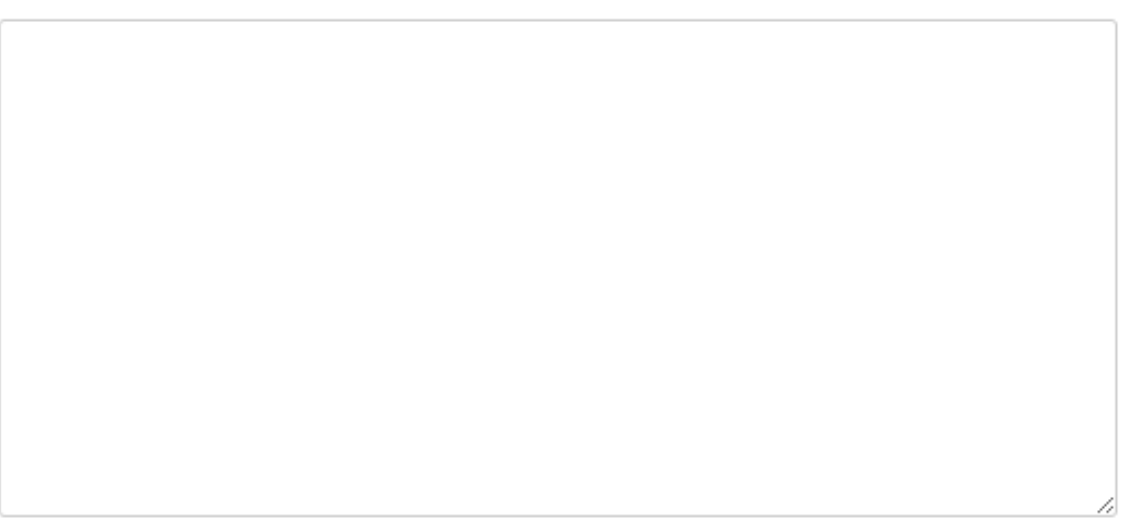

Figure 5. Survey, Being Black While Leading: A study of Black administrators' experiences in U.S. public schools 


\section{APPENDIX D: PREPARED INTERVIEW QUESTIONS}

Please tell me about some positive experiences you have had during your tenure as an

administrator. In what ways, if any, do you see the positive experiences connected to your Blackness?

Please tell me about barriers you have encountered during your tenure as an administrator. In what ways, if any, do you see these barriers connected to your Blackness?

Are there any other barriers you have encountered during your tenure as an administrator?

How does your linguistic capital (i.e., code switching, dialect, and linguistic roots) affect your role as an administrator?

How does your Blackness influence your relationship with students and their families?

Is there anything else you would like to share? 